\title{
On-site data cast doubts on the hypothesis of shifting cultivation in the Late Neolithic (c. 4300-2400 cal. BC). Landscape management as an alternative paradigm
}

\begin{tabular}{|c|c|}
\hline Journal: & The Holocene \\
\hline Manuscript ID & HOL-15-0147.R1 \\
\hline Manuscript Type: & Review \\
\hline Date Submitted by the Author: & $\mathrm{n} / \mathrm{a}$ \\
\hline Complete List of Authors: & $\begin{array}{l}\text { Jacomet, Stefanie; University of Basel, Switzerland, Environmental } \\
\text { Sciences IPAS } \\
\text { Ebersbach, Renate; University of Basel, Environmental Sciences IPAS } \\
\text { Akeret, Örni; University of Basel, Environmental Sciences, IPAS } \\
\text { Antolin, Ferran; University of Basel, Environmental Sciences IPAS } \\
\text { Baum, Tilman; University of Basel, Environmental Sciences IPAS } \\
\text { Bogaard, Amy; Oxford University, School of Archaeology } \\
\text { Brombacher, Christoph; University of Basel, Environmental Sciences IPAS } \\
\text { Bleicher, Niels; Office for Urbanism, Centre for Underwater Archaeology } \\
\text { Heitz-Weniger, Annekäthi; University of Basel, Environmental Sciences } \\
\text { IPAS } \\
\text { Hüster-Plogmann, Heide; University of Basel, Environmental Sciences IPAS } \\
\text { Gross, Eda; Direktion des Innern, Amt für Denkmalpflege und Archäologie } \\
\text { des Kantons Zug } \\
\text { Kühn, Marlu; University of Basel, Environmental Sciences IPAS } \\
\text { Rentzel, Philippe; University of Basel, Environmental Sciences IPAS } \\
\text { Schibler, Joerg; University of Basel, Environmental Sciences IPAS } \\
\text { Steiner, Bigna; University of Basel, Environmental Sciences IPAS } \\
\text { Wick, Lucia; University of Basel, Environmental Sciences IPAS }\end{array}$ \\
\hline Keywords: & $\begin{array}{l}\text { Central Europe, wetland settlements, archaeobotany, archaeozoology, type } \\
\text { of farming, niche construction, use of fire }\end{array}$ \\
\hline Abstract: & $\begin{array}{l}\text { This article brings together in a comprehensive way, and for the first time, } \\
\text { on- and off-site palaeoenvironmental data from the area of the Central } \\
\text { European lake dwellings (a UNESCO World Cultural Heritage Site since } \\
2011 \text { ). The types of data considered are: high-resolution off-site pollen } \\
\text { cores, including micro-charcoal counts, and on-site data, including } \\
\text { botanical macro- and micro-remains, hand-collected animal bones, remains } \\
\text { of microfauna, and data on woodland management (dendrotypology). The } \\
\text { period considered is the Late Neolithic (c. } 4300-2400 \text { cal. BC). For this } \\
\text { period, especially for its earlier phases, discussions of land-use patterns } \\
\text { are contradictory. Based on off-site data, slash-and-burn - as known from } \\
\text { tropical regions - is thought to be the only possible way to cultivate the } \\
\text { land. On-site data however show a completely different picture: all } \\
\text { indications point to the permanent cultivation of cereals (Triticum spp., } \\
\text { Hordeum vulgare), pea (Pisum sativum), flax (Linum usitatissimum) and }\end{array}$ \\
\hline
\end{tabular}


2

opium-poppy (Papaver somniferum). Cycles of landscape use are traceable, including coppicing and moving around the landscape with animal herds. Archaeobiological studies further indicate also that hunting and gathering were an important component and that the landscape was manipulated accordingly. Late Neolithic land-use systems also included the use of fire as a tool for opening up the landscape. Here we argue that bringing together all the types of palaeoenvironmental proxies in an integrative way allows us to draw a more comprehensive and reliable picture of the land-use systems in the Late Neolithic than had been reconstructed previously largely on the basis of off-site data. 


\title{
On-site data cast doubts on the hypothesis of shifting cultivation in the Late Neolithic (c. 4300-2400 cal. BC). Landscape management as an alternative paradigm
}

Review article

\begin{abstract}
This article brings together in a comprehensive way, and for the first time, on- and off-site palaeoenvironmental data from the area of the Central European lake dwellings (a UNESCO World Cultural Heritage Site since 2011). The types of data considered are: high-resolution off-site pollen cores, including micro-charcoal counts, and on-site data, including botanical macro- and micro-remains, handcollected animal bones, remains of microfauna, and data on woodland management (dendrotypology). The period considered is the Late Neolithic (c. 4300-2400 cal. BC). For this period, especially for its earlier phases, discussions of land-use patterns are contradictory. Based on off-site data, slash-and-burn - as known from tropical regions - is thought to be the only possible way to cultivate the land. On-site data however show a completely different picture: all indications point to the permanent cultivation of cereals (Triticum spp., Hordeum vulgare), pea (Pisum sativum), flax (Linum usitatissimum) and opium-poppy (Papaver
\end{abstract}


somniferum). Cycles of landscape use are traceable, including coppicing and moving around the landscape with animal herds. Archaeobiological studies further indicate also that hunting and gathering were an important component and that the landscape was manipulated accordingly. Late Neolithic land-use systems also included the use of fire as a tool for opening up the landscape. Here we argue that bringing together all the types of palaeoenvironmental proxies in an integrative way allows us to draw a more comprehensive and reliable picture of the land-use systems in the Late Neolithic than had been reconstructed previously largely on the basis of off-site data.

\section{Keywords}

Central Europe, wetland settlements, archaeobotany, archaeozoology, type of farming, niche construction, use of fire

\section{Introduction}

The main purpose of this article is to contribute to a long-standing and ongoing debate on the type of land use in the Late Neolithic (LN hereafter; c. 4300-2400 cal. BC; Figure OSM 1) in the regions bordering the Alps (Figure 1). There are generally two extreme positions, which can be summarized as 'permanently 
cultivated plots' versus 'shifting cultivation' models. The first hypothesis is based on archaeobiological on-site-data (for definitions see Jacomet, 2007a) and ethnographic sources, the second rests to a large degree on off-site data, but also experimental work. Whereas off-site evidence is primarily based on pollen and micro-charcoal, on-site evidence relies on archaeobotanical and isotope analyses of a whole range of materials, notably botanical macro- and micro-remains, especially weeds and crops, archaeozoological remains and animal dung, as well as wood remains (for a more thorough description of the evidence and citations, see OSM text, chapter 'State of research and interpretation tools)'.

For many years various researchers have stated that empirical on-site data suggest that slash-and-burn cultivation was not practised (at least not regularly) during the LN in the alpine foreland (see e.g. Brombacher and Jacomet, 1997, p. 270 f.; Hosch and Jacomet, 2004, p. 128 ff.). They favour the idea of a sophisticated landscape management, which also included the use of fire. Fields, once cleared, are thought to have been used relatively permanently and worked intensively, and this included weeding and perhaps even manuring. Yet the idea of shifting cultivation is surprisingly resilient, despite much empirical data against it. The main reason for this is that the more marginal landscapes, including the hilly and mountainous areas of the Alps themselves and the regions bordering them, are considered as less amenable to agriculture, for reasons related to climate and/or 
poorer soil quality (Schier, 2009; Kreuz et al., 2014). This is seen in contrast to Early and partly Middle Neolithic settlement areas (Altsiedellandschaften), which were established from 5500 cal. BC onwards on the most fertile loess soils of Central Europe (see Kreuz, 2012) where slash-and-burn is thought to have been unnecessary because the natural soil fertility was high enough. The alpine areas are thought to have been settled only relatively late (after around $4400 \mathrm{cal}$. BC) by agro-pastoral communities and the only option to farm in such landscapes would have been shifting cultivation (see the so called 'tertiary neolithisation' or 'tertiäre Neolithisierung' after Schier, 2009, p. 19 ff.). Recently however, systematic surveys have illustrated that the prealpine midlands of France and Switzerland were settled by Middle Neolithic communities from 4800 cal. BC onwards (Boisaubert et al, 2001; Ebersbach et al., 2012; Kreuz et al., 2014; Martin, 2014; Martin, 2015).

$<$ INSERT FIGURE 1>

In this article we undertake for the first time a comprehensive and critical comparison of the two types of palaeoenvironmental data (Figure 2) for the central European lake-dwelling area, which should enable us to assess which of the two existing hypotheses are the more plausible or probable. We discuss 
methodological problems and combine the existing evidence in order to present an integrative new view of LN human-animal-environmental interactions. The prealpine environments of Central Europe are probably the world's best location for such an attempt. Here, in the last 30 years or so a large amount of highresolution on- and off-site-data have been gathered and studied (for details see OSM text chapters 'State of research and interpretation tools' and 'Results of onsite data: Basic aspects of animal and plant husbandry'). Indeed the presence of many lakes of glacial origin, which offer excellent preservation conditions, make the region eminently suitable for both types of investigations. During the LN, the so-called 'pile dwellings' on lakeshores and in bogs were in existence (Suter et al., 2009) and these have left some of the best preserved on-site-evidence worldwide. This is underlined by the fact that they were designated as UNESCO World Cultural Heritage sites in 2011 (www.palafittes.org; Menotti and O'Sullivan, 2013; see Figures 3 and 4). The region considered here may therefore also serve as a model region for both integrative archaeological research and earth system studies in the timeframe and region under study.

$<$ INSERT FIGURE 2> 


\section{Shifiting cultivation versus intensive garden cultivation: state of the art}

Here we shall address the two systems under review but refer readers to our more detailed overview of the state of research and interpretation tools available in the OSM chapters 'State of research and interpretation tools' and 'Results of on-sitedata'. Although the main topic of this article is agrarian activities, these cannot be understood without looking at the subsistence economy system as a whole, especially if the research agenda includes reconstructing cycles of land use and the role that fire played in shaping the landscape. Therefore we shall consider different aspects of landscape management activities here.

On-site data

Methodological problems affecting the interpretation of on-site data include data collection techniques, sample sizes and representativeness, questions of interpretation of species composition (e.g. lack of modern analogues for the weed flora) and the problem of the 'patchiness' of wetland settlement layers with many factors influencing the artefact and ecofact composition of the samples. Extensive and profound research in the last few years has contributed to a better understanding of some of the methodological problems, but cannot be discussed in detail in this context (see the above mentioned OSM-chapters). 
On the basis of archaeobiological analyses of more than 100 sites located in different natural environments of the prealpine regions (Figures 3 and 4) we can claim that our knowledge of Neolithic animal and plant husbandry is quite detailed: The economically most important domestic animals in the LN were cattle, pigs and sheep as well as goats (Schibler, 2006; Schibler, 2016 [in press]). For their successful keeping, at least semi-open land was needed. Animals also provided manure which may have played an important role in the agricultural system. An increase in herd sizes, mainly of cattle, towards the end of the LN has been observed (Ebersbach, 2002; Schibler, 2006 and Figure OSM 2). LN plant economy in the area under investigation was based on cereals on the one hand, and pulses, oil, fibre and medicinal plants on the other. The importance of the cultivars changed in the course of the LN (Figure OSM 3; see e.g. Jacomet, 2006; Jacomet, 2007b; Herbig, 2009). For more details see OSM text, chapter 'Results of on-site data', and relevant literature cited there).

<INSERT FIGURE 3>

<INSERT FIGURE 4> 
LN land use is mainly reconstructed with the help of weeds, largely on the basis of the weed spectra of cultivar stocks (see Figure 5 and OSM Table 5 and literature cited there). A compilation of all available data from the Northern Alpine foreland in the late 1990s revealed over 60 wild plant taxa that can be considered weeds in the LN (see tables in Brombacher and Jacomet, 1997, pp. 258-261; OSM Table 5). Beside annuals, perennials were also regularly present. There was a relatively diverse weed flora from the early phases of the LN onwards. Its composition is, however, not directly comparable to modern weed communities, which are dominated by annuals; we see the presence of many opportunistic 'weedy' taxa, which today are more typical of perennial ruderals stands, forest fringes etc., which had also spread onto the fields. The latter taxa were most probably mixed in with woodland, woodland edges, coppiced stands and so on.

$<$ INSERT FIGURE 5>

The results of both classic archaeobotanical studies and FIBS analysis (Functional Attribute studies; see e.g. Bogaard 2004; for more details see OSM Text chapter 'Results of on-site data: Evaluation of the weed spectra') show coincidentally that the richest, most humiferous soils in the surroundings of the settlements were 
used for fields. The often high soil fertility values of the weeds point in the direction of some kind of manuring or to a naturally high soil fertility. Recently the analyses of ${ }^{15} \mathrm{~N}$ isotopes in charred cereal grains from LN contexts have shown that some sort of manuring of the fields must have existed over longer periods (Bogaard, 2012; Bogaard et al., 2013; Styring et al., 2015 [in press]). The regular presence of annuals gives clear indications of highly disturbed soil conditions on the fields. This suggests a labour-intensive management of plots, which must have existed for at least several years, interrupted by only short fallow periods of no more than one to two years. Perennials capable of vegetative propagation by dividuals are also indicative of highly disturbed plots because they can regrow from small parts (see also Kreuz, 2012, chapter 7).

Intensive field tillage appears to have been in existence as early as the earliest phases of the LN, and it becomes even more pronounced from the middle of the fourth millennium cal. BC onwards, when annuals are recorded in increasing quantities. Without a high degree of disturbance, annual weed species would not have survived and would have rapidly become overgrown by competitive, mostly perennial weeds or woodland clearing taxa (see Figure 5).

There are also clear indications that stubble fields and fields left fallow were grazed, which had the side effect of manuring them (the same was noticed already in the early Neolithic LBK (LBK phase I to phase II; Kreuz, 2012). The regular 
presence of winter annuals points to winter cropping of at least some cereals (such as naked wheat or emmer), especially from Horgen times (around $3400 \mathrm{cal}$. BC) onwards. The results of the FIBS evaluation show that cereals were predominantly planted as winter crops (80\% of the cases; e.g. Bogaard et al., 2013). Regular admixtures of small proportions of a second cereal in stocks suggest that some kind of crop rotation was practised, because it is an effective way of keeping pests and diseases at bay as well as to keep soil nutrient contents more balanced (Jacomet et al., 1989, p. 166 ff.).

In wetland settlement layers, animal dung, mostly of ruminants (sheep/goat and cattle) is very often encountered (a very good example is shown on Figure 6). Investigations of plant macro- and micro-remains (mainly pollen) in ruminant dung gave valuable indications of the surfaces on which the animals grazed (see e.g. Kühn et al., 2013; for more details see OSM text, chapter 'Results of on-site data', subchapter 'Evidence based on ruminant dung').

$<$ INSERT FIGURE 6>

In several of the dung pieces of small ruminant investigated in different settlements covering the fifth and fourth millennia cal. BC there are clear 
indications that animals grazed on burnt surfaces of land, as evidenced by high amounts of micro-charcoal (Figure 7a and 7b; Kühn and Wick, 2010).

The seeds, vegetative plant parts and pollen in these pieces of dung point mostly to woodland as grazing ground, and not to the grazing of fields or ruderal/fallow places which were burnt before cereals were sown.

This suggests that LN people burnt parts of the woodland deliberately, probably to obtain more pastures (and also foraging and hunting grounds, see OSM text chapter' Results of on-site-data', subchapters 'Evidence based on open-land-taxa' and 'Evidence based on gathering and hunting') - as is well known from ethnographic sources from climatically similar regions (e.g. Smith, 2011). Remains of dung with plant spectra that would indicate the presence of stubble fields or fallow land do not contain high amounts of micro-charcoal (as shown by the lowermost sample on Figure 7b).

$<$ INSERT FIGURE 7, A AND B>

Furthermore, evidence based on dendrotypology (dendroarchaeology) gives many indications of different types of woodland management, including coppicing and coppiced stands (see e.g. Billamboz, 2014; for more details see OSM chapter 
'Results of on-site data', subchapter 'Evidence based on dendrotypology'). Gathering and hunting played an important role too and may have included targeted or specific landscape management practices, e.g. the tending of hedges or fruit trees. All these types of landscape management were intertwined and cannot be seen in isolation.

\section{Off-site data}

Like those affecting on-site data, the methodological problems of off-site data are manifold: they pertain to data collection techniques (e.g. is micro-charcoal counted or not?; or time resolution of the data), problems of species determination, the explanatory power of species correlated to lake/mire catchment areas, the question of actualistic comparisons, and the possible patchiness of prehistoric landscapes. Generally, as off-site data is extracted from natural environments, the differentiation between natural and anthropogenic impacts on the characteristics observed constitutes a major issue (Sugita, 2007a; Sugita, 2007b; Lechterbeck, 2013). Off-site information on human impact and landscape management is based on observations documenting, for example, rapid changes in woodland species proportions, increases in the percentage of open land in general, peaks of charcoal and an increasing importance of single species or their combination with species which prosper in disturbed or open environments, such as Plantago lanceolata. 
To date, the quality and quantity of off-site data available is unevenly distributed over the prealpine area. The best investigated areas are the regions of Lake Constance and the Hegau (Rösch, et al., 2008; Rösch, et al., 2014; Lechterbeck et al., 2014), while data of the same quality (especially time resolution) from western or southern Switzerland is barely available.

During land-use phases of the fourth and early third millennia cal. BC, many highresolution pollen diagrams of the western part of Lake Constance (Figure 8) show a strong decrease in Fagus in several phases (e.g. Rösch 2013; Rösch et al., 2014; Lechterbeck, 2013; Lechterbeck et al., 2014; ongoing research by. L. Wick; Figure 9).

In parallel, secondary forest elements such as Corylus and Betula and microcharcoal increase. This is interpreted as a replacement of the Fagus-dominated woodland by semi-open or shrubby vegetation, probably also coppiced forests, coinciding with the beginning of the LN. The fluctuating micro-charcoal curves with high peaks are interpreted as indicating woodland burning, especially in the fifth and first half of the fourth millennium, when charred particles are much more frequent than those that are recorded both earlier and later. Therefore, the interpretation is that slash-and-burn cultivation was mainly practised in the earlier phases of the LN (most recently: Rösch, 2013; Rösch et al., 2014, see also OSM text chapter 'Results of off-site data'). In the slash-and-burn model, fields are 
thought to have been rotated in a yearly cycle with long fallow-phases (over ten years) in between.

$<$ INSERT FIGURE 8> $<$ INSERT FIGURE 9>

Recently the main line of interpretation that posits that high frequencies of microcharcoal in off-site data are caused by anthropogenic burning connected to agriculture has triggered a revival of the slash-and-burn-hypothesis for Neolithic farming communities (see compilation in Schier [2009]), although it is a very old conception of how to begin farming in a wooded landscape (e.g. Clark, 1952;

Modderman, 1971; older literature compiled by Troels-Smith, 1990; for a new synopsis see Isaakidou, 2011, p. 92 ff.).

To test the relevance of this interpretation, an experiment in a forested area of south-western Germany was designed (Rösch et al., 2002a; Ehrmann et al., 2014). The results show that slash-and-burn cultivation results in much higher yields than permanent cultivation (even with manuring). But these yields drop to near zero in the second year, forcing the constant relocation of fields. Clearing the forest, burning and preparing the fields leads to an average workload per hectare 
that is much higher than in permanent cultivation systems, and the demand for land is up to 16 times higher than for permanent cultivation. Rösch $(2013$, p. 114) points out that successful burning needs a very high amount of weak wood, i.e. a fallow phase of about 12 years is necessary to produce sufficient wood for another fire.

A further argument for-slash-and-burn cultivation is that there are (almost) no weeds in LN cereal stocks (Rösch et al., 2014, p. 131). This is in agreement with the experiments, where there were almost no weeds at all in the harvest.

The slash-and-burn hypothesis therefore combines a set of observations of LN onsite and off-site data: high charcoal peaks in pollen cores, a dense woodland to deal with at the beginning of the sequence, and finally high settlement mobility with sites occupied for just a few years up to slightly more than a decade (Ebersbach, 2010). The authors mentioned consider that it was the shifting cultivation pattern that could have forced people to move their settlements so frequently. This is seen as representing a contrast to the Early (LBK) and Middle Neolithic settlement patterns; at that time, according to the most commonly accepted hypothesis, settlements were permanent for periods of several hundred years (see e.g. Strien, 2005). As settlement duration and dynamics differ between the Early-Middle and the Late Neolithic, farming techniques must have differed too. Therefore, 
permanent agriculture in Bogaard's (2004) and Kreuz's (2012) view, is accepted for the LBK period, whereas similar results are rejected for the LN.

In a recent article, M. Rösch (2013, p. 115) admits that burning was perhaps independent from agriculture and carried out for other purposes such as hunting or animal husbandry. This is based on observations of an abundance of charcoal in LN coprolites of sheep and goat, but an absence of such charcoal in the Bronze Age (Rösch refers to unpublished data of L. Wick; see below). In an article of 2008 (Rösch et al., 2008, but also 2013, p. 115) Rösch considers that on-site data points to an intensification of agriculture in the later phases of the LN, in the Horgen culture (from around $3400 \mathrm{cal}$. BC onwards). However, off-site data still indicate that slash-and-burn agriculture and chopping down forests were being practised. He argues that it is not clear whether different agricultural regimes were being practised at the same time or whether the former slash-and-burn system was modified and improved, or both. One such modification could have been the fertilisation of permanent fields on the best soils and the preparation of such fields for cultivation by burning wood brought in from a coppiced forest on less fertile soils.

In Final Neolithic Bell Beaker times (around 2300 cal BC) - when settlements are located somewhat further away from the lakes - the slighter evidence of burning is 
seen in connection with the increased importance of animal herding and more extended pastures (Lechterbeck et al., 2014).

\section{Discussion: Which land-use/landscape management is the more likely?}

In the following section, the evidence and methodological aspects of the slash-andburn hypothesis are discussed in detail and compared with other results from all kinds of data that could help us understand LN agricultural techniques and the wider economic and environmental context.

Is a comparison between Early/Middle Neolithic and Late Neolithic micro-charcoal values possible?

From the onset of the LN onwards (in the western part of Lake Constance around 4000 cal. BC) the micro-charcoal values in off-site pollen diagrams are up to five times higher than those of earlier phases (see Figure 9). But can we really compare Early and Middle Neolithic charcoal values with LN values?

In the off-site pollen diagrams from the western part of Lake Constance, microcharcoal curves begin long before the LN; in fact micro-charcoal is present in the Mesolithic, although in lesser quantities than in the LN (e.g. in the diagrams of Durchenbergried and Hornstaad: Rösch, 1990; Rösch, 1992). This is also becoming 
apparent in ongoing work on Mainau (Figure 9), Schleinsee, Degersee and Buchensee (unpublished data by L. Wick). Micro-charcoal is also constantly present in the Early and Middle Neolithic periods, with even some high peaks during the Middle Neolithic in the Mainau diagram (Figure 9). Then, from around 3900 cal. BC onwards until 2500 cal. BC, very high charcoal peaks become visible. This is unsurprising, as the pollen diagrams mentioned are close to LN settlement areas, whereas they are rather more distant from the Early and Middle Neolithic settlement zones. Known Early and Middle Neolithic settlements were located at some distance from the lake rich morainic areas, around $20 \mathrm{~km}$ to the west, in the region of Hegau (LBK Flomborn phase settlement, from 5300 cal. BC onwards, at Hilzingen: Stika, 1991; Middle Neolithic Rössen culture settlement at SingenOffwiesen: Dieckmann et al., 1998; Lechterbeck et al., 2014). It is, however, possible that the Middle Neolithic charcoal peak in the Mainau diagram (around 4600 cal. BC; Figure 9) mirrors settlements nearby whose archaeological traces have so far eluded us (like in the region of Zurich, Erny-Rodmann, 1995; Ebersbach et al., 2012). As cereal type pollen is also present, we can exclude that these traces were left by late hunter-gatherers.

In order to establish whether there was a real difference between micro-charcoal amounts in the Early/Middle Neolithic on the one hand and the LN on the other, we would need to have at our disposal off-site pollen-cores in the immediate 
proximity of Early/Middle Neolithic settlements. There is, however not a single (!) pollen diagram near an Early Neolithic LBK settlement in which micro-charcoal has been systematically investigated. Micro-charcoal was not counted in the Luttersee diagram (near an LBK-settlement in the region of Göttingen, Germany: Beug, 1992); neither was it counted in the floodplain profiles of the LBKsettlement region in the Wetterau (Hesse, Germany: Stobbe, 1996), or at Sersheim (near Stuttgart, Germany: Smettan, 1986).

To conclude, a direct comparison of LN off-site micro-charcoal from the lakedwelling region with Early to Middle Neolithic micro-charcoal from the loessregions is not possible because there are no equivalent data. If we cannot exclude a simple correlation between micro-charcoal peaks and the proximity of a contemporaneous settlement, then it will not be possible to reconstruct different land-use systems based on micro-charcoal values.

\section{Are micro-charcoal values in off-site pollen diagrams related to cultivation?}

Rösch (2013) argues for the existence of a slash-and-burn cultivation regime mainly in the earlier phases of the LN (the so called 'Jungneolithikum', see Figure OSM 1). But he concedes that in the later phases of the $\mathrm{LN}$, from $3400 \mathrm{cal}$. BC onwards, a more permanent cultivation regime may have existed. However, in 
some profiles, the highest and most continuous micro-charcoal values occur after the 'Jungneolithikum', during the Horgen and Corded Ware phases (see Figure 9). This raises the question of why Horgen and Corded Ware people left so many traces in the micro-charcoal record if the landscape was already half-open bushland and cultivation had possibly become more permanent. And why does charcoal occur during all the periods analysed right up to the Late Bronze Age or even later? These questions remain unanswered. Furthermore, charcoal peaks which reflect the burning of woodland to create new fields should result in higher amounts of NAP after burning events, but a detailed analysis to establish whether such a correlation is really visible in the data has never been undertaken. In any case, it becomes obvious that the interpretation of micro-charcoal values is far from straightforward. The sources of charcoal could have been very diverse. A direct link between high micro-charcoal values and cereal growing and its cultivation techniques is merely one possibility among a number of possible interpretations. Another would involve the burning of stubble fields to reduce the weed flora and pests (e.g. Kreuz et al., 2014). Hearth fires or catastrophic fires which burnt the settlements down (the latter was quite frequent, as we know from on-site data) are a further possible source of charcoal. That the input from hearths is likely to be considerable can be demonstrated by a rough and conservative calculation: if fifty households burn just $5 \mathrm{~kg}$ of wood per day, then in the course of 
20 years more than 1800 tons of wood would be turned into ash and charcoal. Since the settlements were located on the shore and were flooded at least seasonally, there should be traces of such quantities of material, at least in off-site sediments close to the shore.

Occasional conflagrations would have increased the amount of charcoal. Be that as it may, if all the micro-charcoal was derived from hearth fires, we should at least see the same quantities in the Bronze Age, which is however not the case. Finally, natural fires could theoretically also be considered, but there are no pre-Neolithic micro-charcoal peaks which point in this direction in the region under consideration.

To conclude, the interpretation of micro-charcoal values in off-site high-resolution pollen diagrams is extremely ambiguous, and clear conclusions about the type of cultivation regimes applied in the LN cannot be drawn. It is however true that the highest average values are reached during the LN. This was obviously a period when burning played a more important role, and it is highly likely that the source of at least a (large?) part of the charcoal comes from 'burning the landscape', whatever the reason was (see below).

Can experiments prove shifting cultivation during the LN? 
Experiments are of great value for testing the plausibility of one or another hypothesis. However, experiments concerning land use are very difficult to set up; for instance the soil conditions are never the same today as they were thousands of years ago. Experiments are therefore not in themselves a proof - just because 'it works' - that prehistoric agricultural techniques were of one type or another.

The group around M. Rösch has tested experimentally the land-use system (slashand-burn) it had reconstructed on the basis of the high charcoal values in off-site pollen diagrams (see previous sections for citations). They concluded that slashand-burn agriculture is the best, if not the only, method to practise successful agriculture with Neolithic tools and methods in a forested area on non-optimal soils. However, their experimental design has several drawbacks. First of all, the experimental plots are situated on soils with a $\mathrm{pH}$-value that is comparatively lower than the usual values of the morainic soils in the hinterland of the lakeshore settlements. This reduces the availability of nitrogen and phosphorous. Rösch et al. (2002b, p. 30 ff.) state that the ash from burning, which raises the $\mathrm{pH}$ value, counteracts this. In addition, the plots were not thoroughly weeded - in opposition to what the weed composition indicates for Neolithic fields (see above). The results from unburnt plots showed that yields were very low or even non-existent, while they were high on burnt plots, where the fire had reduced competition by weeds, raised the $\mathrm{pH}$ value, and removed fine roots from trees and former forest 
vegetation (for yields, see next section). It is hardly surprising that unburnt plots give little yields when they are located on acidic soil and left unattended, but this is not comparable to the techniques used in permanent cultivation systems. The result is therefore an unavoidable consequence of the experimental design and cannot be transferred to prehistoric settings.

Finally, the experimental plots were relatively small and surrounded by dense woodland, a setting which is again not comparable to Neolithic environments, at least not after a few hundred years of human impact, in the periods after $3500 \mathrm{cal}$. BC.

Despite their flaws, these experiments are of great value, because they have shown that shifting cultivation may have been feasible during Neolithic times in temperate woodlands north of the Alps. The experiments have also produced interesting data on workload in relation to yields and on the amount of woodland necessary to maintain a shifting cultivation system for several hundred years. The ratio of field under cultivation to fallow land turned out to be about 1:36 and therefore only $3 \%$ of the area around the settlements could be used for crop growing - the other $97 \%$ being used to produce fertilizer in the form of charcoal (Rösch, 2013). Above all, the higher workload and the much higher demand for land when applying a shifting cultivation system may have caused a problem (as the experiments have also shown). Before burning, the trees had to be cut down, 
the wood dried and transported to be stored in heaps. All this is hard and timeconsuming work and would not have been undertaken without good reason the very high yields, see above).

There are other types of experiments which have shown that permanent cultivation may have worked in Neolithic times. Unfortunately they are located on soils over loess in the Rhineland, and are therefore rather distant from the lakedwelling area. Such an experiment was carried out by Cologne University in the Hambach forest (Lüning and Meurers-Balke, 1980). The results obtained there were later used by Bogaard (2002) for her interpretation of Early Neolithic land use.

To conclude, modern experiments inevitably have their shortcomings; in the best case they can provide insights into how cultivation may have worked. They are, however, not a proof of the existence of one or another cultivation regime in prehistoric times, and their results should not be used as a main line of argument for reconstructing former farming regimes.

What were the yields when applying different forms of cultivation regimes?

Estimates of how high the yields in LN times may have been differ greatly, and we are far from having answered this question (for an overview see Bogaard, 2004, 
table 2.1). Historical data from medieval Europe with very low yield values (450$900 \mathrm{~kg} / \mathrm{ha}$ ) are based on three-field systems which had suffered from permanent cultivation that lasted for centuries and had too little manure input (see Reynolds, 1997). Most authors therefore agree that these data are hardly comparable with Neolithic data. Kreuz (2012, pp. 123-124) assumes a minimal yield of $800 \mathrm{~kg} / \mathrm{ha}$ for cereals and legumes for the early Neolithic LBK if the ratio between sown and harvested crops is 1:10; this corresponds to modern yields considered as 'good' in the traditional agriculture of the central Anatolian highlands where the climate is harsh (Ertug-Yaras, 1997, p. 229). Ethnographic data from a mountainous area in Asturias (northern Spain) show higher yields: there, manured and intensively worked permanent plots produce rather high yields of over $1500 \mathrm{~kg} /$ ha over many years (up to 1800-1900 kg/ha were recorded; Bogaard, 2004, table 2.1; see also Charles et al., 2002). Intensive garden cultivation including irrigation and manuring with up to $40 \mathrm{t} / \mathrm{ha}$ can increase yields to up to $2500 \mathrm{~kg} / \mathrm{ha}$, and for barley even up to $3000 \mathrm{~kg} /$ ha (Ebersbach, 2002, 133 and villages 18A-C). The yields on the experimentally burnt plots at Schwäbisch Hall-Wackershofen and Forchtenberg in south-western Germany mentioned above were very high in the first year (2500-4000 kg/ha; only old strains of cereals considered; Ehrmann et al., 2014, p. 16), being close to the yields obtained by modern agriculture. In the following year, however, they dropped to near zero; the authors conclude that 
permanent cultivation with tillage but without fertilizer is not possible in southwestern Germany. This is in strong contrast to manured and intensively cultivated permanent plots like those in Asturias which continue to give quite high yields for many years. There are also several 'long-term-cereal growing' experiments like the Rothamstead experiment (see Bogaard, 2004, p. 23 f.) that gave reasonable yields over many years, even without manuring (see for more information see Baum et al., submitted).

To conclude: assumptions about the amount of agricultural land needed in Neolithic times can vary dramatically depending on which yield values and which agrarian techniques we use. Quite intensive cultivation methods ('garden-like' to use Bogaard's words, 'park-like' in the early Neolithic LBK according to Kreuz) coincide with small plots of less than half a hectare per person to meet the calorie requirements, while slash-and-burn techniques with a twenty-year-rotation system may need up to ten times more land in the vicinity of the villages and have to be kept undisturbed to allow for forest regrowth to fuel the next burning event. Yields mainly depend on the nutrients available for growing, and these can be kept to a sufficient level by different methods: regular shifting of fields to 'virgin' soils, burning, manuring, or good crop rotation systems including pulses. 
What can on-site data contribute to explain the high micro-charcoal values in off-site locations?

Because off-site micro-charcoal values are clearly difficult to interpret and experiments have drawbacks we must consider other evidence for reconstructing plausible landscape management systems in LN times. On-site data confirm the offsite observations that burning parts of the (wood-) land was an important element of Neolithic land management systems. Micro-charcoal in faeces of sheep and goat in combination with other plant remains point mostly to woodland as grazing grounds (Figure 7). Domestic animals grazed areas of woodland that had previously been burnt, but without any indications that fields existed in the same areas at the same time. Burning may therefore have been a method of creating pastures. We thus have good evidence from on-site data that the main source of high micro-charcoal values in off-site pollen diagrams can be attributed to attempts by LN people to open up the landscape for better grazing, possibly also to create hunting and gathering grounds. Such techniques are known from ethnographic sources, e.g. among North American Forest Indians (e.g. Smith, 2011).

A secondary vegetation rich in shrubs developed on such burnt surfaces - as well as in managed woodland - as clearly shown by the off-site pollen data, but also illustrated by the large amounts of gathered plants and the growing diversity of 
hunted open-land animals in the LN (see OSM text chapter 'Results of on-site data, subchapter 'Evidence based on gathering and hunting'). As Lechterbeck (2013, p. 134 , based on the literature cited there) has noted, burning supports the growth and flowering of hazel. Hazel is relatively fire resistant because of its robust rootstock from which shoots rapidly re-grow. Already present in the undergrowth of the forest, hazel could spread and flower more easily when larger trees were cleared away. However, an unhindered spread of bushes, but also of coppices, is only possible when grazing animals are kept away. As Bleicher and Herbig (2010) have shown, and as corroborated by many historical sources and modern observations, goats successfully prevent the regrowth of forests. It is mainly goats that are important for clearing land overgrown, for instance, by brambles (Rubus fruticosus), and goats may have primarily been kept for such a purpose. The high frequency of Rubus prickles found in sheep/goat dung supports this idea (see e.g. Kühn and Wick, 2010). In any case no secondary forest would grow on patches of previously burnt land if a certain number of goats, sheep and cows were grazing there. If a slash-and-burn system was practised, the rapid and undisturbed regrowth of the forest would have been necessary and hence grazing by small ruminants on burnt woodland patches should have been avoided. What then were the causes of the development of secondary woodland? 
We have very good indications from on-site data that at least parts of the domestic herds were kept away from the settlements, even at a large distance (see e.g. Kühn and Hadorn, 2004), and were probably accompanied by herdsmen and dogs to prevent the animals from grazing where inappropriate. In the LN Federsee basin the settlement of Alleshausen-Grundwiesen was probably a seasonally used camp for cattle and herdsmen (Bleicher, 2009, p. $128 \mathrm{ff}$.), combined with the (summer) cultivation of flax. Here the cultural layers consist almost entirely of cattle dung.

Is the high degree of settlement mobility caused by the slash-and-burn economy? One of the most intriguing traits of LN wetland settlements is their instability, short lifetime and repeated relocation. Recent studies have shown durations of occupation of less than twenty years, in some cases even less than ten years for entire settlements with several dozen houses (Ebersbach, 2010; Ebersbach 2013, 294; Schlichtherle et al., 2011). It is of course tempting to see a causal connection between the huge land requirements of slash-and-burn cultivation and the high degree of settlement mobility. Instability and mobility also occur at a level beyond settlements and within settlements. In the Federsee area several contemporaneous sites were relocated within five- or ten-year cycles at the same rhythm, as Bleicher (2009) has shown. 
Within settlements the life cycles of single houses can be much shorter than the duration of occupation of the settlement as a whole, with 'pioneer houses' often erected two or three years earlier than the majority of the houses, and groups of houses already abandoned after a few years (see e.g. Leuzinger, 2000; Doppler 2013). We therefore conclude that groups of people inhabiting one or several houses, but not comprising the inhabitants of a whole settlement, moved in and out of the settlement at different times; a settlement was not a stable unit in itself. If and how such behaviour is connected to agricultural activity or to other factors such as social tensions, alliances and personal networks, is unknown and open to debate. Some authors have suggested that the rapid depletion of forests -as shown by dendrotypology - caused the relocations, as suitable timber is one of the resources needed in huge quantities when establishing a settlement (see Billamboz, 2010; Billamboz, 2014). In addition, rises in lake levels or demographic growth may have been the reason for the instability and short life of LN settlements (Pétrequin, 2013). Although it is usually difficult or impossible to prove that a connection existed between two settlements directly following each other in time, the striking example of Hornstaad Hörnle 1A suggests that reasons other than following the movement of slash-and-burn fields were at the root of high settlement mobility: the settlement was founded in 3917 cal. BC and grew to around 50 houses before it burnt down in 3910 cal. BC. Immediately afterwards, in 
3909 cal. BC, parts of the settlement were rebuilt, and a new settlement Hornstaad Hörnle 3 - was established only a few hundred metres away (Billamboz, 2006).

It can be assumed that between two settlement phases a succession took place on former cultivated plots, but also on land used for other purposes (Bleicher and Herbig, 2010). It is more or less necessary for settlers to remove regrown vegetation including bushes in order to reclaim former plots for the next settlement phase of fifteen or so years, and fire would be the easiest way to do it. The 'pioneers' may have had the task of preparing the fields for the arrival of the rest of the settlers. Bleicher and Herbig (2010) also argue that the highly interconnected and mobile settlement structure led to almost identical open-land plant spectra in the various settlements, and that domestic animals may have played an important role in building up these meta-populations in the open surfaces. This can be corroborated by spectra from other parts of the lake-dwelling area, for example the region of Zurich. Furthermore, dendrotypology has documented the existence of intensive and lasting woodland management, with different patches of secondary forest kept free of grazing animals and other disturbances to provide the timber favoured for house posts after approximately twenty years. On sites like Saint-Blaise (on Lake Neuchâtel) the repeated use of 
possibly the same forest patches for successive settlement phases at the same site was visible in the growth history of timber (Gassmann, 2007).

In sum, continuous and strategic land and forest management within the same regions may have contributed to the gradual opening of the landscape; this can be seen in all archaeobiological data gathered for the LN, especially after 3000 cal. BC. At the same time there are also indications of additional seasonal movements of people and animals into alpine areas, as evidenced for example in dung pieces containing plants growing at higher altitudes in the Alps (Kühn and Hadorn, 2004). Such movements to higher altitudes - a kind of transhumance - are also indicated by $\mathrm{Sr}^{87} / \mathrm{Sr}^{86}$ isotope analysis of cattle bones (Doppler et al., 2015 [in press]). The use of mountainous areas by herdsmen is also corroborated by off-site pollen data, e.g. from the Vogelsberg, the Eifel region and the Black Forest (see discussion in Kreuz et al., 2014, p. 91 ff. and literature cited there) in which LN activities linked to opening up the forest, including the use of fire, are traceable.

In conclusion, cycles were an integral part of the LN economy. Different kinds of on-site data indicate that burning woodland during the LN played an important role. However we do not see a direct correlation between agricultural activities and burning in our empirical datasets nor do we have proof that high settlement mobility was caused by-slash-and burn agriculture. What is clearly visible, on the 
other hand, is that the landscape was being burnt to create pastures, hunting and gathering grounds. Connections between settlement dynamics, land-use management systems and the individual mobility of people and animals may have been much more complex and caused by many different factors. We are convinced that they can only be traced if all the available data, including settlement archaeology and questions pertaining to the social structures of prehistoric societies, are combined and tackled in a transdisciplinary approach.

The question of the number of weeds in cereal stocks: what is 'a few'?

One of the main arguments used by proponents of a shifting cultivation model is that 'even assuming ear harvest, the small proportion of weeds [...] is striking and resembles the purity of the harvest from the Forchtenberg slash-and-burn fields' (Rösch et al., 2014, p. 129). First of all, the number of weeds per stock at Hornstaad varies greatly - there are from 12 to 140 remains of annuals and from 2 to 49 remains of perennials (see OSM Table 5). The number of taxa is between 4 and 15 annuals and 1 to 8 perennials (see OSM Table 5).

Numbers might indeed be low, but usually there are at least some. The number of weed seeds found in stocks depends on the cleaning stage, but also on the volume of the samples analysed. If we analyse small samples of a maximum of $500 \mathrm{ml}-$ which was in fact almost always the norm (the Hornstaad samples were also very 
small) - conclusions about the number of weeds present on Neolithic fields are purely hypothetical. A much more thorough analysis of uncleaned stored crops remains to be undertaken.

LN stocks represent very short-term, single events at a given stage of cleaning. This may contrast with, for example, Early Neolithic cleaning residues in pits (Bogaard, 2011b; Kreuz, 2012), which could represent longer term accumulations of numerous single (but similar) events (Kreuz, 1990). Over time, a larger number of weeds (together with chaff) may have accumulated. The generally higher average quantity of weeds in LBK pits could reflect this.

The number of taxa in LBK pits, however, is fairly similar to that found in the most diverse Hornstaad stocks (see OSM 5). Therefore, Rösch et al.'s statement (2014, p. 130) that weed percentages at Hornstaad are lower compared to Vaihingen is not comprehensible. It would be more fruitful to compare the weed spectra from LBK pits to the weed spectra from mixed samples in lakeshore settlements, which may represent several years of accumulation. Such evaluations remain to be undertaken but are difficult to carry out because of the mixed character of the assemblages.

Differences in the weed and cereal spectra of the successive Neolithic periods 
We do not see major differences (or almost no differences at all) between the weed spectra of the Early Neolithic and those of the LN (see OSM Table 5). In both periods, annual weeds dominate in the stocks (but also in mixed samples; see Figure 5) and many of the weed taxa are the same (see OSM Table 5). The few visible differences may be explained by the 1000 years or more that elapsed between the two periods, a time when new taxa from outside Central Europe may have reached our region, and by differences in the surrounding landscape and vegetation. We cannot, on the basis of the weed evidence, agree with Rösch et al.'s argument (2014, p. 130) that land use systems of the later stages of the Final and Late Neolithic were totally different from the land use of the Early Neolithic. Thus we also do not understand why Rösch (see cited works) and also Schier (2009) accept intensive land use in the Early Neolithic and reject it for (mainly the earlier stages of) the LN. In our view it is not surprising that the few FIBS evaluations of LN weed spectra by Bogaard $(2004 ; 2011$ a) gave the same results as those of the Early Neolithic: they point to permanent fields, which were intensively worked and maybe even manured (Bogaard et al., 2013; Styring et al., 2015 [in press]).

Furthermore, there appears to be no great differences in terms of taxa composition when different periods of the LN are compared. In stocks of the earlier phases annual weeds are even more widespread than in stocks of the Horgen culture (late fourth millennium cal. BC). In the mixed assemblages, however, the number of 
annual weeds increases in the second half of the LN, which could indicate that winter cereal growing became more important and that the plots were more intensively maintained; perhaps pigs played some part here in working (and manuring) the fields as their numbers rise markedly with the onset of the Horgen culture (Figure OSM 2). Overall, we do not see substantial differences: permanent cultivation continued. This is also corroborated by the $\mathrm{N}$ isotope analyses of the 1200-year-long stratigraphic sequence recorded at Sipplingen on Lake Constance (Styring et al., 2015 [in press]).

The difference of the cereal spectra 'of the Late Neolithic from the phases before and after' (Rösch et al., 2014, p. 130) constitutes a further argument in favour of the shifting cultivation hypothesis. Here the authors refer to the dominance of tetraploid naked wheat in the first half of the fourth millennium cal. BC; but this type of naked wheat also appears in the second half of the fourth millennium in larger amounts (Figure OSM 3), and is still present in later periods (although never again in such large amounts). Moreover, the argument that there are more cereals in the earlier phases of the $\mathrm{LN}$ is not convincing given that a systematic comparison of density values, for example, has not been carried out. On the basis of the evidence from mixed assemblages (containing large amounts of chaff remains) we do not see such a difference. 
More fundamental and greater differences in the weed and cultivar spectra appear with the onset of the Bronze Age (BA). South of the Alps this is apparent as early as the earliest phases of the BA, as the new on-site investigations of Early BA sites on the fringes of Lake Garda show (Perego, 2015). North of the Alps such developments become apparent with the beginning of the Middle to Late BA. We are therefore in complete agreement with Rösch et al.'s (2014) statement that the 'extensive ard land-use systems of the Bronze Age were different in terms of agricultural practices' (see also Jacomet and Brombacher, 2009). Not surprisingly, a FIBS analysis of charred chaff and weed remains of Middle BA pits in central Switzerland showed that cereal growing was carried out at that time on larger, extensively worked fields (Zibulski, 2001; Bogaard, 2011a).

Differences between modern experimental fields and Neolithic weed spectra - how long does it take for Neolithic-type weed floras to develop?

The fact that the composition of the weed flora is different from today's fields cannot be taken as an argument to prove the existence of shifting cultivation (see above and OSM text chapter 'Results of on-site-data indicative of the farming regime and landscape management'). A comparison of the wild plant lists of experimental fields treated with slash-and-burn in Wackershofen and Forchtenberg (Rösch et al., 2002a) with Neolithic weed spectra (Figure 5 and OSM 
Table 5) clearly shows that they are completely different. It is therefore not possible to propose an interpretation of Neolithic weeds on the basis of the experimental wild plant spectrum. The closest similarity is provided by the spectra of the experimental 3-field-system at Wackershofen. This is in agreement with our expectations but suggests rather the opposite of shifting cultivation.

The results of experiments assessed in the course of the Hambach experiment (near Cologne, Germany) mentioned earlier showed that Neolithic-type weed floras need ten years or more to develop (Bogaard, 2002; Bogaard, 2004; Bogaard and Jones, 2007). Although these experiments had several drawbacks, at least they showed that there were weeds on the fields. With shifting cultivation there should have been no weeds at all (let us recall the statement cited above referring to the 'purity of the harvest from the Forchtenberg slash-and-burn fields' by Rösch et al., 2014), either in the stocks nor in the mixed samples from the cultural layers. As this is not the case, we reject the hypothesis of a LN shifting cultivation based on empirical on-site data.

\section{Soil fertility issues in the $L N$}

All on-site data point to fertile soils. The nature of the soils in the loess belt of Central Europe is a matter of debate (see e.g. Eckmeier et al., 2007). What is certain is that in very dry regions like parts of the Wetterau there were highly fertile 
czernozems that had developed naturally on a small scale (pers. comm. Prof. H. Thiemeyer, Frankfurt). It is not certain whether luvisols later developed out of these, or whether they had developed directly on loess in less dry regions. The latter is supposed by some researchers (Brönnimann and Rentzel [in prep.]). To summarize, soils in the loess landscapes were fertile and well suited to agriculture, but czernozem development is likely to have been regionally limited. Regarding soil fertility, therefore, the prealpine luvisoils that developed on the subsoil of the last glaciation were probably not all that different from luvisoils on loess. It has yet to be determined how different prealpine Neolithic luvisols on morainic ground were from luvisols in Early Neolithic loess landscapes. We therefore do not agree with Schier's (2009) view that a spread of Neolithic agriculture beyond the fertile loess areas was only made possible through slash-and-burn cultivation.

Really poor soils, mostly on siliceous bedrock, exist in several mountainous areas of Central Europe. In regions like the southern part of Westphalia (Rothaargebirge) (Pott, 1986), or the central Black Forest, or the Emmental in Switzerland, we know of cultivation regimes known as 'Haubergswirtschaft'. Such regimes included the cyclical use of patches of land cleared by burning. It was not possible to produce a cereal crop on these parcels of land (mostly rye was sown, a cereal that grows extremely well on poor soils but which was not introduced to our region before the Late Roman period); they were intended to provide 
firewood, charcoal, bark for tanning etc. and the burnt surface was used as pasture. Similar regimes are known in Scandinavia, e.g. in Finland (Lahtinen and RowleyConwy, 2013). In such regions, slash-and-burn may have been the only option to produce a crop. Whether slash-and-burn was also practised in the surroundings of some Neolithic sites of unknown character in the south-western French Alps remains to be clarified; there, einkorn, a cereal of which certain strains grow well on poor soils today (Bogaard et al., 2016), plays a quite important role (Martin, 2014).

Some new isotope data (Bogaard et al., 2013) even suggest that manuring was practised from the Early Neolithic onwards. Similar results were obtained by Kanstrup et al. (2014) for the fourth millennium cal. BC onwards in Denmark. In Hornstaad there are indications that the manuring of fields in which different cereals were grown was not the same, and there is also variation in the data obtained in different parts of the settlement (Bogaard et al., 2013; Styring et al., 2015 [in press]), suggesting that manuring rates varied spatially and according to the species grown in a given year. All in all it seems that the interdependence between animal herding and plant cultivation was strong (Ebersbach, 2002). To be efficient, manuring needs a certain minimal number of domestic animals on the one hand, and on the other hand manuring has important implications for the investment in land and territorial claims by farming groups (see Bogaard, 2012). A 
Tamil proverb puts this succinctly: 'No fodder, no cattle, no manure, no crop' (cited by Thomas, 2000, p. 4). The question of soil fertility and how to keep it high (by shifting fields or manuring, not forgetting crop rotation systems) is surely one of the most important research issues related to land-use management.

To conclude, empirical weed data point to permanent cultivation from the beginning of the LN onwards with no profound differences from what we know for earlier phases of the Neolithic. There are no convincing arguments, based on empirical data, that support the existence of shifting cultivation. Soil fertility was no doubt a crucial issue, but it can be kept at a high level by using different techniques, and recent isotope data indicate that manuring played an important part already in the Neolithic.

\section{Conclusions}

Although the on-site results presented in this article are very encouraging, archaeobiologists are still far from being in a position to reconstruct the LN economy and environment comprehensively. First of all, future research needs to reach a better understanding of wetland layer formation processes (ongoing SNF Project IPAS Basel, no. CR30I2_149679). Based on this, much more research on the functional attributes of weed taxa is needed. Analyses of ${ }^{15} \mathrm{~N}$ isotopes in cereal grains (and perhaps other cultivars) will be crucial to understand manuring 
techniques - which in turn are connected to animal keeping strategies. Much more dung analysis is also needed, and more systematic comparisons between on-site micro- and macro-remain data. Nevertheless the existing data already allows us to draw a quite plausible picture of how the LN economy may have worked and what impact it had on the landscape.

On-site weed data point to permanent, rather intensively tilled fields and maybe even the use of manure. However we cannot exclude that on a freshly cleared piece of land cultivation was practised for a short time - if fire was used. Some kind of infield out-field system may well have existed, with most fields cultivated permanently and intensively in the vicinity of the villages and some out-fields occasionally prepared on burnt forest land. Moreover, there was a very close and intense relationship between plant and animal husbandry.

Settlement archaeology and dendroarchaeology both show that relocations and cyclical patterns were an integral part of the LN economy. Settlements were shortlived and people moved around within settlement areas (or even between them) with their domestic animals. For clearing land they undoubtedly used fire as a landscape management tool, as shown by micro-charcoal in dung and off-site data. On-site data also confirms that gathering (see e.g. Antolin et al, 2015 [in press]) and hunting were highly important. Part of the gathering system consisted 
probably also of woodland management, including coppicing and perhaps pollarding. Such an intensive use of wild resources lets us suppose that people manipulated the landscape to obtain higher and more secure yields of wild fruits and good timber for building purposes. An opening of the landscape also favours successful hunting. And the necessity to provide good grazing grounds for domestic animals (especially cattle) was crucial. As our on-site data also show, this landscape management included the use of fire, creating in the process mosaics of micro-environments such as liminal areas, bush-rich landscapes, etc. This fits well with niche-construction theories (e.g. Smith, 2011). All in all, LN people had a successful survival strategy (see also Baum et al., submitted). It was clearly resilient, able to cope with changing weather conditions or short-term climatic fluctuations.

Using on-site data - in combination with an alternative interpretation of off-site data - the surface areas needed to feed humans and animals can be estimated in a more realistic way. On-site data are therefore an important basis for model-based simulations on a small scale (e.g. Baum, 2014; Baum et al., submitted, and ongoing research by Baum). These modelling attempts have shown that the amount of open or semi-open land is fundamentally different depending on which farming regime it relies on (Figure 10; Baum, 2014). On the basis of a combination of on- and offsite data we consider the model shown in Figure 10a as the most reliable. 
Modelling approaches have the potential to open-up wider archaeological perspectives on the practices and impacts of early agrarian societies (Whitehouse and Kirleis, 2014). Moreover, the results can be incorporated into land cover simulations on a larger scale, e.g. of the Early Anthopocene (Kaplan et al., 2009; Kaplan et al., 2011; Ruddiman, 2004; Ruddiman, 2013; Ruddiman et al., 2011; Ellis et al., 2013). For all this, it is crucial to bring together - in an integrative way - as many types of palaeoenvironmental proxies as possible in order to gain more plausible insights into the landscapes that existed thousands of years ago. We believe that this article contributes to this goal.

As a final offering, we propose to re-write the conclusions of Lechterbeck et al. (2014, p. 108): 'Some very elaborate land use models based on experimental data suggest that the expansion of secondary forest elements was caused by "slash and burn" or "swidden" cultivation (Rösch, 2013; Schier et al., 2013)'. A more appropriate formulation, based on a comprehensive knowledge of on-site data, would be: 'The expansion of secondary forest elements was caused by different landscape management practices which included the use of fire'.

\section{Acknowledgments}

This study was conducted partly within several projects of the SNF (Swiss National Foundation), mainly project no. K-13K0-117897 (The role of Animal Fodder in 
Neolithic and Bronze Age Subsistence Economy and its Palaeoecological Implications), and the currently running project no. CR30I2_149679 (Formation and Taphonomy of Archaeological Wetland Deposits: Two Transdisciplinary Case Studies and their Impact on Lakeshore Archaeology). Information was also provided by the ongoing SNF project CR12I2_143815/1 on $\mathrm{Sr}^{87} / \mathrm{Sr}^{86}$ isotope analyses (PI: J. Schibler). We also thank the canton und town of Zürich who have funded former investigations and especially the ongoing research on the recently excavated site of Zürich Parkhaus Opéra. The first author thanks Angela Kreuz (Landesamt für Denkmalpflege Wiesbaden, Germany) for her valuable comments on an earlier version of this article. We also thank Urs Leuzinger (Amt für Archäologie des Kantons Thurgau) for information on finds of ards and ardmarks, and Manfred Rösch who kindly provided unpublished data (Mainau diagram). Finally, we thank two anonymous reviewers whose comments enabled us to make the text much more concise, and Madeleine Hummler for help with our English wording.

\section{References}

Antolin F, Bleicher N, Brombacher C, et al. (2015 [in press]) Quantitative approximation to large-seeded wild fruit use in a late Neolithic lake 
dwelling. The case study of layer 13 of Parkhaus Opéra in Zürich (Central Switzerland). Quaternary International doi: 10.1016/j.quaint.2015.08.003.

Antolin F, Brombacher C, Kühn M, et al. (2016 [in press]) Archäobotanische Untersuchungen der Horgen-zeitlichen Siedlungen von Zürich Parkhaus Opéra. In: Bleicher N and Harb C (eds) Zürich Parkhaus Opéra: Wirtschaft und Umwelt. Monographien der Kantonsarchäologie Zürich: Zürich.

Baum T. (2014) Models of wetland settlement and associated land use in SouthWest Germany during the fourth millennium b.c. Vegetation History and Archaeobotany 23(1): 67-80.

Baum T, Nendel O, Jacomet S, Ebersbach R (in prep) Slash and burn or weed and manure? Modelling implications and limitations of Neolithic crop cultivation in pre-alpine wetland sites. Submitted to Vegetation History and Archaeobotany.

Beug H-J (1992) Vegetationsgeschichtliche Untersuchungen über die Besiedlung im unteren Eichsfeld, Landkreis Göttingen, vom frühen Neolithikum bis zum Mittelalter. Neue Ausgrabungen und Forschungen in Niedersachsen 20: 261339.

Billamboz A (2006) Dendroarchäologische Untersuchungen in den neolithischen Ufersiedlungen von Hornstaad-Hörnle. Siedlungsarchäologie im 
Alpenvorland IX. Forschungen und Berichte zur Vor- und Frühgeschichte in Baden-Württemberg 98: 297-414. Stuttgart: Konrad-Theiss Verlag.

Billamboz A (2010) Dendroarchéologie sur les bords du lac de Constance: De la forêt au village, que de bois devant la maison palafittique! In: Matuschik I, Strahm C, Eberschweiler B, et al. (eds) Vernetzungen. Aspekte siedlungsarchäologischer Forschung. Festschrift für Helmut Schlichtherle zum 60. Geburtstag. Freiburg i. Br.: Lavori Verlag, 81-94.

Billamboz A (2014) Regional patterns of settlement and woodland developments: Dendroarchaeology in the Neolithic pile-dwellings on Lake Constance (Germany). The Holocene 24(10): 1278-1287.

Bleicher N (2009) Altes Holz in neuem Licht. Archäologische und dendrochronologische Untersuchungen an spätneolithischen Feuchtbodensiedlungen in Oberschwaben. Berichte zu Ufer- und Moorsiedlungen Südwestdeutschlands V. Materialhefte zur Archäologie in Baden-Württemberg 83. Stuttgart: Konrad Theiss Verlag. Bleicher N and Herbig C (2010) Der Federsee: Landschaft und Dynamik im Neolithikum. In: Matuschik I, Strahm C, Eberschweiler B, et al. (eds) Vernetzungen. Aspekte siedlungsarchäologischer Forschung. Festschrift für Helmut Schlichtherle zum 60. Geburtstag. Freiburg i. Br.: Lavori Verlag, 95112. 
Bogaard A. (2002) Questioning the relevance of shifting cultivation to Neolithic farming in the loess belt of Europe: evidence from the Hambach Forest experiment. Vegetation History and Archaeobotany 11(1-2): 155-168.

Bogaard A. (2004) Neolithic Farming in Central Europe. An archaeobotanical study of crop husbandry practices, London: Routledge.

Bogaard A. (2011a) Farming practice and society in the central European Neolithic and Bronze Age: an archaeobotanical response to the secondary products revolution model. In: Hadjikoumis A, Robinson E and Viner S (eds) The Dynamics of Neolithisation in Europe. Studies in honour of Andrew Sherratt. Oxford: Oxbow Books, 266-283.

Bogaard A (2011b) Plant use and crop husbandry in an early Neolithic village: Vaihingen an der Enz, Baden-Württemberg. Frankfurter Archäologische Schriften 16. Bonn: Habelt.

Bogaard A (2012) Middening and Manuring in Nelithic Europe: Issues of Plausibility, Intensity and Archaeological Method. In: Jones R (ed) Manure Matters. Historical, Archaeological and Ethnographic Perspectives. Farnham, Surrey: Ashgate Publishing Ltd., 25-39.

Bogaard A, Fraser R, Heaton THE, et al. (2013) Crop manuring and intensive land management by Europe's first farmers. Proceedings of the National Academy of Sciences of the United States of America 110(31): 12589-12594. 
Bogaard A, Hodgson J, Nitsch E, et al. (2016) Combining functional weed ecology and crop stable isotope ratios to identify cultivation intensity: a comparison of cereal production regimes in Haute Provence, France and Asturias, Spain. Vegetation History and Archaeobotany 25: 57-73

Bogaard A and Jones G (2007) Neolithic Farming in Britain and central Europe: contrast or continuity? Proceedings of the British Academy 144: 357-375.

Boisaubert J-L, Mauvilly M, Murray C (2001) Apports et intégration des données de l'A1 à la connaissance du 5e millénaire av. J.-C. dans la région des Trois Lacs. Jahrbuch der Schweizerischen Gesellschaft für Ur- und Frühgeschichte 84: $125-131$.

Brombacher C and Jacomet S (1997) Ackerbau, Sammelwirtschaft und Umwelt: Ergebnisse archäobotanischer Untersuchungen. In: Schibler J, HüsterPlogmann H, Jacomet S, et al. (eds) Ökonomie und Ökologie neolithischer und bronzezeitlicher Ufersiedlungen am Zürichsee. Ergebnisse der Ausgrabungen Mozartstrasse, Kanalisationssanierungen Seefeld, AKAD/Pressehaus und Mythenschloss in Zürich. Monographien der Kantonsarchäologie Zürich 20, Zürich und Egg: Direktion der öffentlichen Bauten des Kantons Zürich, 220-279.

Brombacher C and Jacomet S (2003) Ackerbau, Sammelwirtschaft und Umwelt. In: Zwahlen H (ed) Die jungneolithische Siedlung Port-Stüdeli. Ufersiedlungen 
am Bielersee 7, Bern: Paul Haupt Verlag, 66-86.

Brönnimann D and Rentzel P (in prep.) Böden, Landschaftsentwicklung und archäologische Strukturen in den frühneolithischen Fundstellen Gächlingen. Ergebnisse der Geoarchäologie. In: Altorfer K and Chantal H (eds) Die frühneolithischen Fundstellen von Gächlingen, Kt. Schaffhausen. Schaffhausen.

Charles M, Bogaard A, Jones G, et al. (2002) Towards the archaeobotanical identification of intensive cereal cultivation: present-day ecological investigation in the mountains of Asturias, northwest Spain. Vegetation History and Archaeobotany 11(1-2): 133-142.

Clark, JGD (1952) Prehistoric Europe: the economic basis. London: Methuen.

Dieckmann B, Hoffstadt J, Maier U, et al. (1998) Zum Stand der Ausgrabungen auf den 'Offwiesen' in Singen, Kr. Konstanz. Archäologische Ausgrabungen in Baden-Württemberg 1997: 43-47.

Doppler T (2013) Archäozoologie als Zugang zur Sozialgeschichte in der Feuchtbodenarchäologie. Forschungsperspektiven am Fallbeispiel der neolithischen Seeufersiedlung Arbon Bleiche 3 (Schweiz). PhD thesis 2013, University of Basel, Faculty of Sciene, DOI: http://edoc.unibas.ch/26017/. Doppler T, Gerling C, Heyd V, et al. (2015 [in press]) Changing cattle herding strategies over time? $\delta^{13} \mathrm{C}$ in Neolithic and Bronze Age herbivore bone 
collagen from the lower Lake Zurich basin, Switzerland. Quaternary International doi:10.1016/j.quaint.2015.09.007

Ebersbach R (2002) Von Bauern und Rindern. Eine Ökosystemanalyse zur Bedeutung der Rinderhaltung in bäuerlichen Gesellschaften als Grundlage zur Modellbildung im Neolithikum. Basler Beiträge zur Ur- und Frühgeschichte 15, Basel: Schwabe Verlag.

Ebersbach R (2003) Paleoecological reconstruction and calculation of calorie requirements at lake Zurich, Switzerland. Landschaftsarchäologie und Geographische Informationssysteme: Prognosekarte, Besiedlungsdynamik und prähistorische Raumordnungen = The Archaeologiy of Landscpes and Geographic Information Systems: Predictive Maps, Settlement Dynamics and Space and Territory in Prehistory. Symposium 15.-19. Oktober 2001 Wünsdorf, Land Brandenburg. Archäoprognose I. Wünsdorf: Publikationen des Brandenburgischen Amtes für Denkmalpflege und Archäologischen Landesmuseums, 69-88.

Ebersbach R (2010) Vom Entstehen und Vergehen. Überlegungen zur Dynamik von Feuchtbodenhäusern und -siedlungen. In: Matuschik I, Strahm C, Eberschweiler B, et al. (eds) Vernetzungen. Aspekte siedlungsarchäologischer Forschung. Festschrift für Helmut Schlichtherle zum 60. Geburtstag. Freiburg i. Br.: Lavori Verlag, 41-50. 
Ebersbach R (2013) Houses, Households and Settlements: Architecture and Living Spaces. In: Menotti F and O'Sullivan A (eds) The Oxford Handbook of Wetland Archaeology. Oxford: Oxford University Press, 283-301.

Ebersbach R, Kühn M, Stopp B, et al. (2012) Die Nutzung neuer Lebensräume in der Schweiz und angrenzenden Gebieten im 5. Jtsd. v. Chr. - Siedlungs- und wirtschaftsarchäologische Aspekte. Jahrbuch Archäologie Schweiz 95: 7-34.

Eckmeier, E, Gerlach, R, Gehrt, E and Schmidt, MWI (2007) Pedogeneesis of Szernozems in Central Europe - a review. Geoderma 139: 288-299

Ehrmann O, Biester H, Bogenrieder A, et al. (2014) Fifteen years of the Forchtenberg experiment-results and implications for the understanding of Neolithic land use. Vegetation History and Archaeobotany 23(1): 5-18.

Ellis EC, Kaplan JO, Fuller DQ, et al. (2013) Used planet: A global history. Proceedings of the National Academy of Sciences 110(20): 7978-7985.

Erny-Rodmann C (1995) Von der Urlandschaft zur Kulturlandschaft. Pollenanalytische Untersuchungen an drei Uferprofilen aus dem Zürcher 'Seefeld' zu anthropogenen Vegetationsveränderungen seit dem Mesolithikum, PhD Thesis, Basel University.

Ertug-Yaras F (1997) An ethnoarchaeological study of subsistence and plant gathering in central Anatolia. PhD thesis, Washington University, St.Louis: UMI Dissertation Services. 
Gassmann A (2007) L'exploitation de quelques chênaies durant le Lüscherz et l'Auvernier-Cordé ancien: quand les habitats du village littoral de SaintBlaise/Bains des Dames (Neuchâtel, Suisse) allaient aux bois. In: Besse M (ed), Sociétés Néolithiques. Des faits archéologiques aux fonctionnements socio-économiques. Actes du 27 e colloque interrégional sur le Néolithique (Neuchâtel, 1 et 2 octobre 2005). Cahiers d'Archéologie Romande 108. Lausanne, 101-114.

Herbig C (2009) Recent archaeobotanical investigations into the range and abundance of Neolithic crop plants in settlements around Lake Constance and in Upper Swabia (south-west Germany) in relation to cultural influences. Journal of Archaeological Science 36: 1277-1285.

Hosch S and Jacomet S (2004) Ackerbau und Sammelwirtschaft. Ergebnisse der Untersuchung von Samen und Früchten. In: Jacomet S, Schibler J and Leuzinger U (eds) Die neolithische Seeufersiedlung Arbon Bleiche 3: Wirtschaft und Umwelt. Archäologie im Thurgau 12, Frauenfeld: Amt für Archäologie des Kantons Thurgau, 112-157.

Isaakidou V (2011) Farming regimes in Neolithic Europe: gardening with cows and other models. In: Hadjikoumis A, Robinson E and Viner S (eds) The Dynamics of Neolihisation in Europe. Studies in honour of Andrew Sherratt. Oxford: Oxbow Books, 90-112. 
Jacomet S (2006) Plant Economy of the Northern Alpine Lake Dwelling area 3500-2400 BC cal. Environmental Archaeology 11(1): 64-83.

Jacomet S (2007a) Plant Macrofossil Methods and Studies. Use in Environmental Archaeology. In: Elias SA (ed) Encyclopedia of Quaternary Science. Oxford: Elsevier, 2384-2412.

Jacomet S (2007b) Neolithic plant economies in the northern alpine foreland from 5500-3500 BC cal. In: Colledge S and Conolly J (eds) The Origins and Spread of Domestic Plants in Southwest Asia and Europe. Walnut Creek CA: Left Coast Press, 221-258.

Jacomet S and Brombacher C (2009) Geschichte der Flora in der Regio Basiliensis seit 7500 Jahren: Ergebnisse von Untersuchungen pflanzlicher Makroreste aus archäologischen Ausgrabungen. Mitteilungen der Naturforschenden Gesellschaften beider Basel 11: 27-106.

Jacomet S, Brombacher C and Dick M (1989) Archäobotanik am Zürichsee. Ackerbau, Sammelwirtschaft und Umwelt von neolitischen und bronzezeitlichen Seeufersiedlungen im Raum Zürich. Ergebnisse von Untersuchungen pflanzlicher Makroreste der Jahre 1979-1988. Zürcher Denkmalpflege, Monographien 7, Zürich: Orell Füssli.

Kanstrup M, Holst MK, Jensen PM, et al. (2014) Searching for long-term trends in prehistoric manuring practice. $\delta 15 \mathrm{~N}$ analyses of charred cereal grains from 
the 4th to the 1st millennium BC. Journal of Archaeological Science 51: 115125.

Kaplan JO, Krumhardt KM, Ellis EC, et al. (2011) Holocene carbon emissions as a result of anthropogenic land cover change. Holocene 21(5): 775-791.

Kaplan JO, Krumhardt KM and Zimmermann N (2009) The prehistoric and preindustrial deforestation of Europe. Quaternary Science Reviews 28: 3016-3034.

Kreuz A (1990) Searching for 'Single-Activity Refuse' in Linearbandkeramik Settlements. An Archaeobotanical Approach. In: Robinson DE (ed) Experimentation and Reconstruction in Environmental Archaeology. Oxford: Oxbow Books, 63-76.

Kreuz A (2012) Die Vertreibung aus dem Paradies? Archäobiologische Ergebnisse zum Frühneolithikum im westlichen Mitteleuropa. Berichte der RömischGermanischen Kommission 91(2012): 23-196.

Kreuz A, Märkle T, Marinova E, et al. (2014) The Late Neolithic Michelsberg culture - just ramparts and ditches? A supraregional comparison of agricultural and environmental data. Praehistorische Zeitschrift 89(1): 72-115.

Kühn M and Hadorn P (2004) Pflanzliche Makro- und Mikroreste aus Dung von Wiederkäuern. In: Jacomet S, Leuzinger U and Schibler J (eds) Die jungsteinzeitliche Seeufersiedlung Arbon Bleiche 3. Umwelt und Wirtschaft. 
Archäologie im Thurgau 12, Frauenfeld: Amt für Archäologie des Kantons Thurgau, 327-350.

Kühn M, Maier U, Herbig C, et al. (2013) Methods for the examination of cattle, sheep and goat dung in prehistoric wetland settlements with examples of the sites Alleshausen-Täschenwiesen and Alleshausen-Grundwiesen (around 2900 BC) at Lake Federsee, south-west Germany. Environmental Archaeology 18(1): 43-57.

Kühn M and Wick L (2010) Pflanzenreste in Koprolithen von Schafen und Ziegen: Was frassen die kleinen Wiederkäuer von Pfäffikon-Burg? In: Eberli U (ed) Die horgenzeitliche Siedlung Pfäffikon-Burg. Monografien der Kantonsarchäologie Zürich 36. Zürich und Egg: Fotorotar, 256-261.

Lahtinen M and Rowley-Conwy P (2013) Early Farming in Finland: Was there Cultivation before the Iron Age (500 BC)? European Journal of Archaeology 16(4): 660-684.

Lechterbeck J (2013) Evaluation of economic activity trhough palynological data: Medelling agricultural pressure onlandscape (REVEALS and LOVE). In: Kerig T and Zimmermann A (eds) Economic archaeology. From structure to performance in European archaeology. Universitätsforschungen zur Prähistorischen Archäologie 237, Bonn: Rudolf Habelt GmbH, 129-141. 
Lechterbeck J, Kerig T, Kleinmann A, et al. (2014) How was Bell Beaker economy related to Corded Ware and Early Bronze Age lifestyles? Archaeological, botanical and palynological evidence from the Hegau, Western Lake Constance region. Environmental Archaeology 19(2): 95-113.

Leuzinger U (2000) Die jungsteinzeitliche Seeufersiedlung Arbon Bleiche 3. Befunde, Archäologie im Thurgau 9, Frauenfeld: Amt für Archäologie des Kantons Thurgau.

Lüning J and Meurers-Balke J (1980) Experimenteller Getreideanbau im Hambacher Forst, Gemeinde Elsdorf, Kr. Bergheim/Rheinland. Bonner Jahrbücher 180: 305-344.

Maier U (2001) Archäobotanische Untersuchungen in der neolithischen Ufersiedlung Hornstaad-Hörnle IA am Bodensee. In: Maier U and Vogt R (eds) Siedlungsarchäologie im Alpenvorland VI. Botanische und pedologische Untersuchungen zur Ufersiedlung Hornstaad-Hörnle IA. Forschungen und Berichte zur Vor- und Frühgeschichte in Baden-Württemberg 74. Stuttgart: Konrad Theiss Verlag, 9-384.

Martin L (2014) Premiers paysans des Alpes. Alimentations végétale et agriculture au Néolithique. PhD Thesis, Université Paris I (Panthéon-Sorbonne) and Basel University. Rennes et Tours: Presses universitaires de Rennes et Presses universitaires François-Rabelais de Tours, 220 p. 
Martin L (2015) Plant economy and territory exploitation in the Alps during the Neolithic (5000-4200 cal. bc): first results of archaeobotanical studies in the Valais (Switzerland). Vegetation History and Archaeobotany 24(1): 6373.

Menotti F and O'Sullivan A eds (2013) The Oxford Handbook of Wetland Archaeology, Oxford: Oxford University Press.

Modderman PJR (1971) Bandkeramiker und Wanderbauerntum. Archäologisches Korrespondenzblatt 1: 7-9.

Perego R (2015) Contribution to the development of the Bronze Age plant economy in the surroundings of the Alpes: An archaeobotanical case study of two Early Bronze Age sites in Northern Italy (Lake Garda region), PhD Thesis, Basel University.

Pétrequin P (2013) Lake-Dwellings in the Alpine Region. In: In: Menotti F and O’Sullivan A (eds) The Oxford Handbook of Wetland Archaeology. Oxford: Oxford University Press, 253-267

Pott R (1986) Der pollenanalytische Nachweis extensiver Waldbewirtschaftungen in den Haubergen des Siegerlandes. In: Behre K-E (ed) Anthropogenic Indicators in Pollen Diagramms. Rotterdam und Boston: A.A. Balkema, 125134. 
Rösch M (1990) Vegetationsgeschichtliche Untersuchungen im Durchenbergried. Siedlungsarchäologie im Alpenvorland II. Forschungen und Berichte zur Vorund Frühgeschichte in Baden-Württemberg 37. Stuttgart: Konrad Theiss Verlag, 9-64.

Rösch M (1992) Human impact as registered in pollen record: some results from the western Lake Constance region, Southern Germany. Vegetation History and Archaeobotany 1: 101-109.

Rösch M (2013) Land use and food production in Central Europe from the Neolithic to the Medieval period: change of landscape, soils and agricultural systems according to archaeobotanical data. In: Kerig T and Zimmermann A (eds) Economic Archaeology: From Structure to Performance in European Archaeology. Universitätsforschungen zur Prähistorischen Archäologie 237, Bonn: Habelt Verlag, 109-128.

Rösch M, Ehrmann O, Herrmann L, et al. (2002a) An experimental approach to Neolithic shifting cultivation. Vegetation History and Archaeobotany 11(12): $143-154$.

Rösch M, Ehrmann O, Herrmann L, et al. (2002b) Zu den Wurzeln von Landnutzung und Kulturlandschaft - Sieben Jahre Anbauversuche in Hohenlohe: eine Zwischenbilanz. Fundberichte aus Baden-Württemberg 26: 21-44. 
Rösch M, Ehrmann O, Kury B, et al. (2008) Spätneolithische Landnutzung im nördlichen Alpenvorland: Beobachtungen - Hypothesen - Experimente. In: Dörfler W and Müller J (eds) Umwelt - Wirtschaft - Siedlungen im dritten vorchristlichen Jahrtausend Mitteleuropas und Südskandinaviens. OffaBücher 84,Neumünster: Wachholtz Verlag, 301-315.

Rösch M, Kleinmann A, Lechterbeck J, et al. (2014) Botanical off-site and on-site data as indicators of different land use systems: a discussion with examples from Southwest Germany. Vegetation History and Archaeobotany 23(1): 121-133.

Ruddiman WF (2004) Early Anthropogenic Overprints on Holocene Climate. PAGES news 12(1): 18-19.

Ruddiman WF (2013) The Anthropocene. Annual Review of Earth and Planetary Sciences 41: 45-68.

Ruddiman WF, Crucifix MC and Oldfield FA (2011) Introduction to the earlyAnthropocene Special Issue. Holocene 21(5): 713-713.

Schibler J (2006) The economy and environment of the 4th and 3rd millennia BC in the northern Alpine foreland based on studies of animal bones. Environmental Archaeology 11(1): 49-64.

Schibler J (2016 [in press]) Zooarchaeological results from Neolithic and Bronze Age wetland and dryland sites in the Central Alpine Foreland: Economic, 
ecologic and taphonomic relevance. In: Albarella U (ed) Oxford Handbook of Zooarchaeology. Oxford: Oxford University Press: XX-XX.

Schier W (2009) Extensiver Brandfeldbau und die Ausbreitung der neolithischen Wirtschaftsweise in Mitteleuropa und Südskandinavien am Ende des 5. Jt. v. Chr. Prähistorische Zeitschrift 84: 15-43.

Schier W, Ehrmann O, Rösch M, et al. (2013) The economics of Neolithic swidden cultivation: results of an experimental long-term project in Forchtenberg (Baden-Württemberg, Germany). In: Kerig T and Zimmermann A (eds) Economic Archaeology: From Structure to Performance in European Archaeology. Universitätsforschungen zur Prähistorischen Archäologie 237, Bonn: Habelt Verlag, 97-108.

Schlichtherle H, Vogt R, Maier U, Herbig C, Schmidt E, Ismail-Meyer K, Kühn M, Wick L, Dufraisse A (2011) Die endneolithische Moorsiedlung Bad Buchau Torwiesen II am Federsee. Band 1: Naturwissenschaftliche Untersuchungen. Hemmenhofener Skripte 9, Freiburg im Breisgau: Janus-Verlag. Smettan HW (1986) Pollenanalytische Untersuchungen zur Vegetations- und Siedlungsgeschichte der Umgebung von Sersheim, Kr. Ludwigsburg. Fundberichte aus Baden-Württemberg 10: 367-421.

Smith BD (2011) General patterns of niche construction and the management of 'wild' plant and animal resources by small-scale pre-industrial societies. 

366(1566): 836-848.

Stika H-P (1991) Die paläoethnobotanische Untersuchung der linearbandkeramischen Siedlung Hilzingen, Kreis Konstanz. Fundberichte aus Baden-Württemberg 16: 63-104.

Stobbe A (1996) Die holozäne Vegetationsgeschichte der nördlichen Wetterau. Paläoökologische Untersuchungen unter besonderer Berücksichtigung anthropogener Einflüsse. Dissertationes Botanicae 260, Berlin / Stuttgart: J. Cramer.

Strien H-C (2005) Familientraditionen in der bandkeramischen Siedlung bei Vaihingen/Enz. In: Lüning J, Fridrich C and Zimmerman A (eds) Die Bandkeramik im 21. Jahrhundert: Symposium in der Abtei Brauweiler bei Köln vom 16.9.-19.9.2002. Internationale Archäologie. Arbeitsgemeinschaft, Symposium, Tagung, Kongress 7, Rahden: Marie Leidorf Verlag, 189-197. Styring A, Maier U, Stephan E, et al. (2015 [in press]) Cultivation of choice: new insights into farming practices at Neolithic lakeshore sites. Antiquity doi:10.15184/aqy.2015.192.

Sugita S (2007a) Theory of quantitative reconstruction of vegetation I: pollen from large sites REVEALS regional vegetation composition. Chemosphere 17(2): 229-241. 
Sugita S (2007b) Theory of quantitative reconstruction of vegetation II: all you need is LOVE. Holocene 17(2): 243-257.

Suter PJ, Schlichtherle H, Arnold B, et al. (2009) Pfahlbauten : UNESCO WelterbeKandidatur 'Prähistorische Pfahlbauten rund um die Alpen' = Palafittes : candidature au Patrimonie mondial de l'UNESCO 'Sites palafittiques préhistoriques autour des Alpes' = Palafitte : candidatura a patrimonio mondiale dell'UNESCO 'Siti palafitticoli preistorici dell'arco alpino' = Pile dwellings $=$ Kolišč , Bern: Palafittes, Archäologischer Dienst des Kantons Bern.

Thomas CK (2000) The role of draught cattle and buffaloes in sustainable agriculture in India. Draught Animal News 32: 4-11.

Troels-Smith J (1990) Experiments in forest clearance and slash-and-burn agriculture in Draved forest in the 1950's. In: Robinson DE (ed) Experimentation and reconstruction in environmental archaeology. 0xford: Oxbow Books, 75-76.

Whitehouse NJ and Kirleis W (2014) The world reshaped: practices and impacts of early agrarian societies. Journal of Archaeological Science 51(0): 1-11.

Zibulski P. (2001) Archäobotanische Untersuchungen der Makroreste (Samen, Früchte und Dreschreste). In: Gnepf Horisberger U and Hämmerle S (eds) Cham-Oberwil, Hof (Kanton Zug). Befunde und Funde aus der 
2

3

4

5

9

Glockenbecherkultur und der Bronzezeit. Antiqua 33, Basel: Verlag

Schweizerische Gesellschaft für Ur- und Frühgeschichte, 150-166, 285-295, 333-339. 
Figure 1. Map of the area considered in this article. From Euratlas http://www.euratlas.com, slightly modified by $\mathrm{S}$. Jacomet.

$254 \times 190 \mathrm{~mm}(72 \times 72$ DPI $)$ 
Fig. 2, Jacomet et al.

\section{- on-site-studies}

- Archaeobotany, Archaozoology, Dendrocharchaeology

- Part of the Archaeological Sciences

- Main interest: Palaeoeconomy
- off-site-studies

- Vegetation History / Land Cover Change Part of the Ecological Sciences: Palaeoecology

- Main interest: Palaeoenvironment

Figure 2. Scheme showing the relationships between the different types of palaeoenvironmental data considered in the text (on- and off-site data). By S. Jacomet. $254 \times 190 \mathrm{~mm}(72 \times 72 \mathrm{DPI})$ 
Fig. 6, Jacomet et al.

Figure 3. Map of Neolithic and Bronze Age sites of the northern alpine lake dwelling area for which archaeobotanical data exist. Neolithic sites date between 4300 and 2400 cal BC, Bronze Age sites between 1900 and $850 \mathrm{cal} \mathrm{BC}$. On most of the sites several settlement layers of different ages were investigated. For detailed legend and references see Tables OSM 1 and OSM 2.

$254 \times 190 \mathrm{~mm}(72 \times 72$ DPI $)$ 
Figure 4. Major regions of Switzerland and location of Neolithic and Bronze Age wetland and dryland sites with archaeozoological data. For detailed legend and citations see Tables OSM 3 and 4 (from Schibler, 2016, [in press]).

$169 \times 121 \mathrm{~mm}(300 \times 300 \mathrm{DPI})$ 
Figure 5. Numbers of annual (blue) and perennial (red) weeds in Early and Late Neolithic cereal and flax stores (from Maier, 2001; Brombacher and Jacomet 1997; Brombacher and Jacomet 2003; Kreuz 2012) compared to those of the experimental fields at Wackershofen and Forchtenberg (data from the latter after Rösch et al., 2002a). Abbreviations: LBK = LinearBandKeramik (Early Neolithic); LN = Late Neolithic; Ho = Hornstaad Hörnle I, AH (Archaeological Horizon) 2 (burnt layer); numbers in brackets mean number of stocks analysed; $\mathrm{C}=$ Cereals; $\mathrm{F}=$ Flax; $\mathrm{MOZ}=$ Zürich-Mozartstrasse; $\mathrm{PS}=$ Port-Stüdeli; $\mathrm{AB} 3=$ Arbon

Bleiche 3; stat. $=$ results of statictical analyses (Spearman Rank Correlation) $;$ in total 80 LN stocks

considered. LNE = Earlier Phases of Late Neolithic (ca 4300-3600 cal BC; LNL = Later phases of Late Neolithic $(3300-2500$ cal BC); ExpFo $==$ Experimental Fields in Forchtenberg; WiBu (1) winter sawn cereals, burned surface; SuBu = summer sawn cereals, burned surface; FaUnb = Fallow land, unburned;

$\mathrm{FaBu}=$ Fallow land, burned; Perm $=$ permanent cultivation; ExpWa3- $\mathrm{F}=$ Experimental Fields in Wackershofen, 3-field System; number in brackets = number of the relevee in Rösch et al., 2002a. For more details see Tables OSM 1 and OSM 5 $254 \times 190 \mathrm{~mm}(72 \times 72 \mathrm{DPI})$ 
Figure 6. Presence of ruminant dung in the settlement layer of Zurich Parkhaus Opéra layer 13 (Horgen culture, 3175-3157 cal BC). Figure by F. Antolin. The photograph shows a goat/sheep dung piece (photograph by G. Haldimann, CIPNA Basel University). For more details see Antolin et al., 2016 [in press]. $254 \times 190 \mathrm{~mm}$ (72 x 72 DPI) 


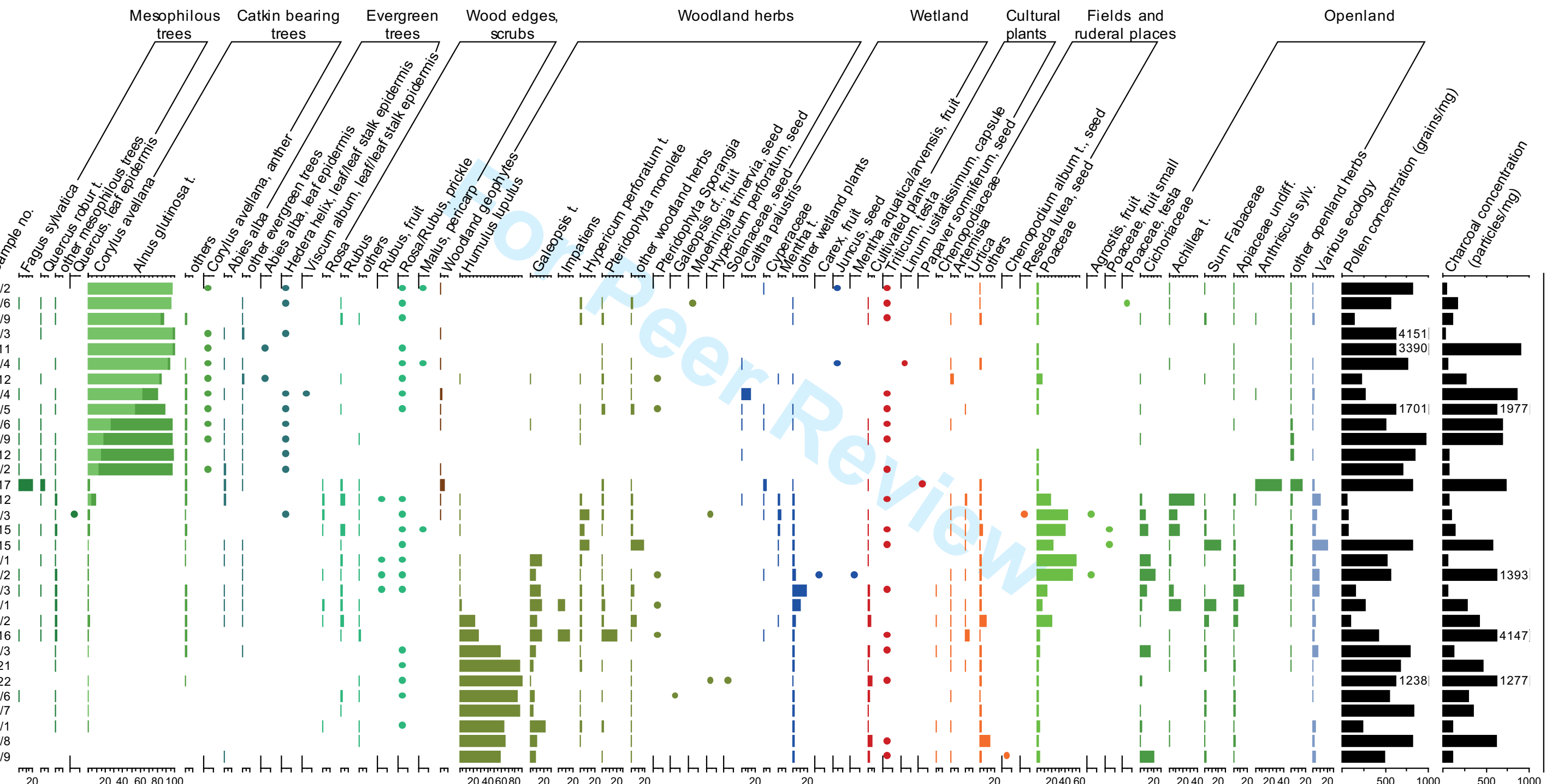


Fig. 5, Jacomet et al.

Figure 8. Location of the high-resolution pollen diagrams (black dots) in the western Lake Constance region (after Rösch et al., 2014, p. 122) (white squares represent archaeological sites with archaeobotanical investigations).

$254 \times 190 \mathrm{~mm}(72 \times 72$ DPI) 


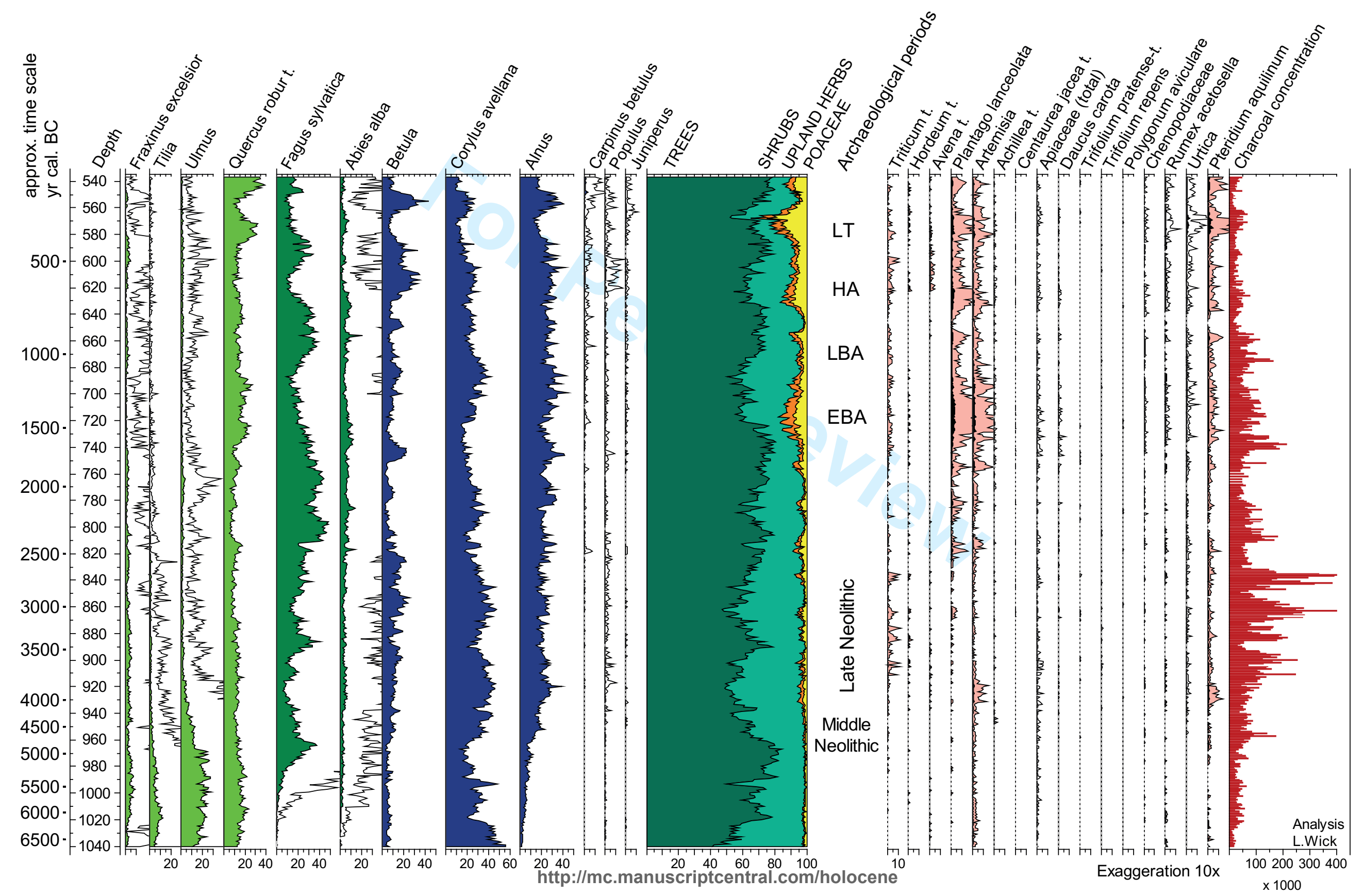


Fig. 3, Jacomet et al.

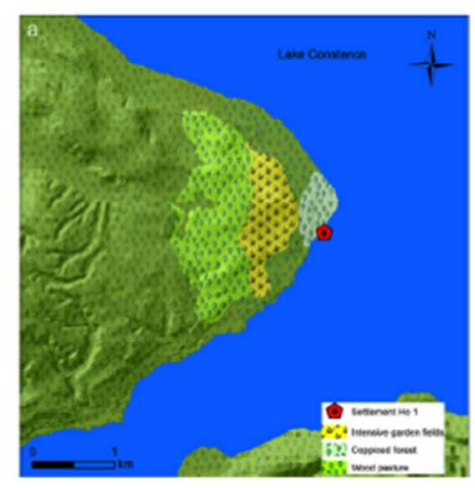

a) Intense cultivation

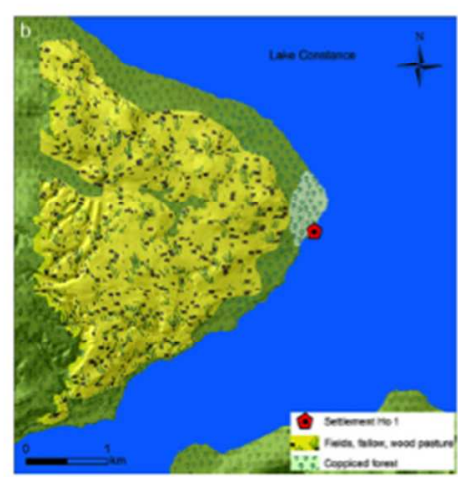

b) Shifting cultivation

Figure 10. Possible amounts of open and shrubby land around a Late Neolithic settlement (Hornstaad-Hörnle I, Lake Constance, 3918-3905 cal BC). Modelling attempt based on a) permanent fields with intensive cultivation (left) and b) the existence of slash-and-burn cultivation (from Baum, 2014). $254 \times 190 \mathrm{~mm}(72 \times 72 \mathrm{DPI})$ 
On-site data cast doubts on the hypothesis of shifting cultivation in the Late Neolithic (c. 4300-2400 cal. BC). Landscape management as an alternative paradigm

\section{Online Supplementary Materials (OSM): OSM text}

\section{Supplement to Introduction:}

Whether or not the wetland sites mirror economically specialised settlements or socially marginalised groups is a matter of debate see e.g. Whittle, 1996, p. 216 ff.; Pétrequin et al., 2005). In the hinterland near the lakes only a few coeval settlements are known, but recent survey programmes show peaks of settlements and activities related to high settlement densities on the lake shores (e.g. Mauvilly and Boisaubert, 2005; dendroarchaeological studies also indicate such dense occupation, e.g. Billamboz, 2014). On the basis of archaeobotanical on-site data we do not see - at first sight - any difference in plant husbandry between lakeshore sites and the few hinterland settlements when taphonomic filters are taken into account (see e.g. Jacomet, 2013); this, however, has to be evaluated in greater detail.

\section{State of research and interpretation tools}

\section{Off-site data}

Off-site pollen data can be used as a proxy for the intensity of land use (Figure 2, print text). When considering the area discussed in this article we must mention in particular the ten (and more) high-resolution pollen diagrams that exist; these mostly come from sediments from the central part of small lakes in the western part of the area around Lake Constance investigated from the 1980s onwards by the research group around M. Rösch (for an overview see fig. 5 and table 7, p. 108 in Lechterbeck et al., 2014). This is currently the best-investigated area with regards to pollen analysis in Europe. The profiles are independently dated by more than 200 radiocarbon dates, and the time models have been carefully revised (by applying a Bayesian approach). The main aim of these studies was to reconstruct not only the vegetation history but also the type of human use of the landscape since the Neolithic. The places investigated lie mainly in the region of Upper Swabia, the western part of Lake Constance (Rösch et al., 2014) and the Hegau 
which is located somewhat further to the west (Lechterbeck et al., 2014; fig. 5). In these bogs and (mostly small) lakes there was no evidence of direct human influence on deposition. The human impact of nearby settlements, however, has left traces in such sediments in the form of open-land pollen or micro-charcoal. As numerous investigations of the last decade have shown, it is rather complicated to reconstruct quantitatively from pollen data the degree to which the landscape was open or the type of use it was put to (see e.g. Sugita, 2007a; Sugita, 2007b; Broström et al., 2008; Hellmann et al., 2009; Gaillard et al., 2010; Trondman et al., 2014). The reason for this is that pollen data catch the amalgamate effects of a large number of partly unidentified processes on pollen rain. If there are no empirical actualistic data available as a basis for comparison, it seems impossible to reconstruct in detail specific single practices of unknown consequences from the sum of all the processes.

On-site data

The main aim of archaeobiological on-site investigations is to reconstruct the subsistence economy (Figure 2, print text). We define subsistence as 'all activities which are necessary to satisfy pure biological needs (not only food but also clothing and shelter) as well as essential social and spiritual requirements' (Jacomet and Schibler, 2010).

Generalities/Basics. Biological on-site data encompass the disciplines of archaeobotany and archaeozoology as well as dendrotypology (for definitions see Jacomet, 2007a, and Billamboz, 2014). Here we describe in greater detail the state of the art and the grounds on which interpretation are based because this is rarely found in the palaeoecological literature. We concentrate on wetland sites; indeed the sheer quantity of remains of wild and domesticated species and high resolution both in time and space on such sites can supply many empirical facts for the reconstruction of former land use.

The main difference between on- and off-site data is that the remains we investigate on human occupation sites (on-site data) are part of a sediment that is to a very large degree of anthropogenic origin. Human behaviour, the activities in a settlement in the past, belongs to the most important factors influencing the spectra of bioarchaeological remains in anthropogenic layers (so-called cultural transformation, after Schiffer, 1991; Schiffer, 2002; summarized in Jacomet, 2007a). 
Examining on-site data is essential for establishing how the remains entered a given context and its formation processes (for basics, see e.g. Davis, 1987; Kreuz, 1990; Kreuz, 1995; Kreuz, 2012; Van der Veen, 2007; Jacomet, 2013). Remains from cultural layers represent a mixture of single events and accumulations of remains over longer periods of settlement activity, transformed by synchronous and later taphonomic processes.

We have to make sure that we do not take single events, which might be unrepresentative, as 'the average'. On the other hand, if we can reconstruct such single events, these can give extremely valuable information on specific activities or past plant assemblages (e.g. animal dung or uncleaned cereal stocks, see below). Detailed and representative intra-site investigations form the basis of any relevant synthesis (e.g. Jacomet and Brombacher, 2005; Antolin et al., 2015 [in press]).

Natural influences also play a role in layer formation (natural transformation sensu Schiffer, 1991; Schiffer, 2002): as lakeshore settlements were located in a highly dynamic environment - the lake shore - we can detect water influences or phases of drying out, or relocations (are remains in situ or not?), and there may also be signs of erosion or selective preservation (see e.g. Jacomet et al., 1989; Leuzinger, 2000; Ismail-Meyer et al. 2013, p. 331; Bleicher and Ruckstuhl, 2015). Bog settlements are less influenced by such natural factors, but there organic preservation is subject to other selection mechanisms (see e.g. Herbig, 2006). In general, the reasons why organic materials are well preserved in organic waterlogged layers are poorly understood (e.g. Bleicher and Schubert, 2015).

All these aspects show that the interpretation of on-site data is in no way straightforward and influenced by even more factors than off-site data. For interpretation we use several so-called 'middle range tools' (tools from contemporary situations such as the ecological values of weeds that help explain past situations; after Binford and Binford, 1968).

The numerous comprehensive archaeobiological investigations of the last decades have however made clear that the principle of 'uniformitarianism' (meaning 'the present is the key to the past') can often not be transferred to past situations when humans are involved.

Archaeobotany. Figure 3 in the print text shows the state of the archaeobotanical on-site research concerning the Neolithic lake dwellings in the vicinity of the Alps (for more details see Jacomet, 2006; Jacomet, 2007b; Jacomet, 2008; Jacomet, 2009; Herbig, 2009). In particular, plant macroremains like seeds, fruits, chaff or 
wood were investigated (here we do not treat on-site pollen data which are only available in small quantities).

Systematic research over the last forty years has yielded a large amount of macroremain data from over 100 settlement layers from all parts of the northern Alpine foreland (Figure 6 in the print text) as well as from other regions like Slovenia, see Tolar et al., 2011) and most of these data are stored in the ArboDat database (Kreuz and Schäfer, 2014).

A recent example of a comprehensively-sampled settlement layer is the Horgen cultural layer 13 of the Zürich-Parkhaus Opéra site (Bleicher and Harb, 2015), which is currently being examined (Figure OSM 4; Antolin et al., 2016 [in press]). In wetland settlement layers a much larger spectrum and a greater number of remains and taxa are present than in dryland sites (burnt layers may be an exception). It is mostly waterlogging that causes their preservation. For the methodology used in our investigations (sampling, recovery etc.) we refer to published works on this subject (e.g. Hosch and Zibulski, 2003; Jacomet and Brombacher, 2005; Vandorpe and Jacomet, 2007; Tolar et al., 2009; Antolin et al., 2015; Steiner et al., 2015).

In order to reconstruct environmental conditions we use the following 'middle range tools': besides ecological grouping, based on actualistic (modern or ethnographic) data (see Behre and Jacomet, 1991), we apply statistical methods like Spearman's rank correlation for finding correlations between, for example, wild plants and cultivated taxa (e.g. Hosch and Jacomet, 2004). The so-called 'closed assemblages', such as uncleaned cereal stocks which still contain the weeds that grew on the fields, constitute an important source of information. Their spectra can be evaluated in the way mentioned above. More recently, they were used in functional attribute studies aimed at reconstructing crop growing conditions and land management practices (Functional interpretation of Botanical Surveys or FIBS; Jones 2002; Bogaard 2004 and 2011; Bogaard et al., 2016); for explanations see below, chapter 'Results of on-site data: Evaluation of the weed spectra based on their life forms, other functional attributes and ecological demands'). Also very recently, isotope research (like ${ }^{14} \mathrm{~N} /{ }^{5} \mathrm{~N}$ ) was carried out on the cereal grains found in such assemblages, which suggested that manuring took place (Bogaard, 2012; Bogaard and Outram, 2013; Bogaard et al., 2013).

Archaeozoology. The state of the art concerning archaeozoology is presented by Schibler (e.g. Schibler, 2006 and Schibler, 2016, [in press] and Figure 4, print text). 
Data on hand-collected large bones (mostly mammals) from over 100 settlements are available. Archaeozoological (bone) data are also stored in a database (OSSOBOOK; Schibler, 1998; Kaltenthaler et al., 2015). Several overviews and evaluations, including basics of methodology, are published (see Schibler, 2006; Schibler, 2016 [in press] and citations there).

The state of research concerning small bones (mostly of birds, fishes and amphibians) or mussels, snails or insects, which are extracted from soil samples (often the same as those used for botanical macroremains) is at present less satisfactory but information on such kinds of remains, indicative, for example, of fishing techniques has nonetheless greatly improved over the last fifteen years (e.g. Hüster Plogmann, 2004; Lemdahl, 2004; Schmidt, 2011).

Dendrotypology. Dendrotypology is a dendroarchaeological approach that was developed from the 1980s onwards in parallel to pure dendrochronological dating (for a recent summary of the methodology and results from the western Lake Constance region see Billamboz, 2014). Dendrotypology rests on the classification of timber (based on the tree rings) according to tree age, growth patterns and the degree of stem conversion, which form the basis for creating dendro-groups. These provide an insight into the structure and dynamics of the forest stands that were exploited (from clearing activities and coppicing practices to forest degradation). In our investigation area such analyses have mainly been developed since the 1980s by A. Billamboz in the western Lake Constance region (Billamboz, 2014) and in Upper Swabia (primarily in the Federsee region; Bleicher, 2009); the situation is less satisfactory in the rest of Switzerland but is however improving (Suter and Francuz, 2010; Bleicher et al., 2013).

Other interpretation tools. As further interpretative tools we also use the results of experimental archaeology (such as experimental fields: Bogaard, 2002; Schier et al., 2013; Ehrmann et al., 2014) and ethnographic data (e.g. Charles et al., 2002; Smith, 2011a and b). In the latter case we must ensure that examples from similar climatic regions are used. Ethnographic data cited in the literature on Native North American forest communities and their abilities to shape a wooded landscape in temperate climate zones is most promising (e.g. Smith, 2009; Smith, 2011a; more indications of burning in the overview by Scherjon et al., 2015).

\section{Results of on site-data: Basic aspects of animal and plant husbandry}


During the Late Neolithic (hereafter LN), domestic animals and cultivated plants played an important role in the economy. Beside cattle, pigs and sheep as well as goats there were dogs too. In the LN, all these domestic animals continue to be important, in variable proportions (Schibler, 2006; Schibler, 2016 [in press]), with increasing herd sizes observed towards the end of the LN (Ebersbach, 2002; Schibler, 2006; see Figure 4, print text).

For overviews on the LN plant economy see Herbig, 2009; Jacomet, 2006; Jacomet, 2007b; Jacomet, 2008; Jacomet, 2009; Jacomet, 2014). The main cereals were different wheat taxa. Tetraploid naked wheat (Triticum turgidum s.l. ${ }^{1}$ ) and emmer (Triticum dicoccum) were the most important taxa, whereas einkorn (including two-grained Triticum monococcum) is quite rare and only locally important (e.g. Karg and Märkle, 2002). There were always considerable quantities of six-rowed barley (Hordeum vulgare). The other main cultivars were flax (Linum usitatissimum) and opium poppy (Papaver somniferum); pea (Pisum sativum) appears rarely in larger amounts. However, pea may be underrepresented; as the ongoing investigations on the Horgen culture layer 13 of Zürich Parkhaus-Opéra show: there are many fragments of subfossil pea pods, which may have been overlooked in earlier investigations (Antolin et al., 2016 [in press]). Although the quantification of plant remains represents a methodological challenge and the results are hypothetical, model calculations give us an idea that carbohydrate-rich sources were highly important to meet the daily demand for calories (Gross et al. 1990; Schibler and Jacomet, 2010; on the importance of gathered fruits, see below).

The reasons behind the change of the importance of cultivars in the course of the LN (Figure OSM 3) are not yet clear. A changing environment may have played a role, but also - and perhaps primarily - various cultural influences from the East or the West (see e.g. Jacomet, 2007b; Kreuz et al., 2014).

\section{Results of on-site data indicative of the farming regime and landscape management, incl. difficulties in reconstructing the Late Neolithic weed flora}

\footnotetext{
1 The nomenclature of scientific plant names for cultivars follows the traditional classification, after Zohary, Hopf and Weiss (2012).
} 
For several reasons it is difficult to define what a weed was in LN times. As weeds are crucial for land-use reconstruction, the reasons for this are explained here:

\section{Mostly mixed assemblages}

The settlement layers of the LN lakeshore settlements are mixed assemblages containing the refuse from all kinds of different activities. Among others, there are hundreds of thousands of (mainly) chaff remains of cereals, but also capsule fragments of flax, pod fragments of pea or even capsule fragments of poppy, to a very large extent preserved in a subfossil state (for a new and up-to-date example see Antolin et al., 2016 [in press]). There is also a large variety of open-land taxa in the same samples; many of them can be attributed to the 'crop weeds' ecological group by actualistic grouping (see compilation in Brombacher and Jacomet, 1997, p. $258 \mathrm{ff}$.). Such a combination of cultivar remains and weed taxa reflects the typical refuse found in agrarian settlements, well comparable with, for example, refuse in Early Neolithic Linearbandkeramik (LBK) pits, although the latter is present in charred form only (see e.g. Kreuz, 2012).

\section{Cleaning stages in mixed assemblages not clearly identifiable}

For mixed refuse layers in lake-dwelling sites it is difficult to define the cleaning stages. If we compare the combination of remain types and taxa with ethnographic data (e.g. Hillman, 1984; Jones, 1987; Jones, 1990) we see that remains of winnowing and perhaps also sieving are present in the cultural layers, including the weeds (for an attempt, see Jacomet et al., 1989, p. 169). We therefore conclude that annual weed taxa which are still known as crop weeds today were also crop weeds in LN times. This is corroborated by statistical approaches (Spearman rank correlation; see Hosch and Jacomet, 2004, fig. 101, p. 130) conducted for the site of Arbon-Bleiche 3 (around 3380 cal. BC). There, some typical annual weeds (partly the same as those already considered to be weeds on the basis of actualistic approaches) but also some perennials showed a high degree of correlation with cultivars (Figure 5 in the print text; OSM Table 5).

Unknown (or hypothetical) processes before the harvest (tillage, weeding, harvesting methodology)

Tillage practice must have been different from what we know from ethnographic sources (for a thorough description of examples of the latter, see Kreuz, 2012). 
There are no undisputable finds of ploughs (ards), the few known examples being far from straightforward to interpret (see Brombacher and Jacomet, 1997, p. 270); only hoe-like instruments are regularly found (see e.g. Leuzinger, 2002). Whether the ardmarks found in the eastern Alps (canton of Grisons, south-eastern Switzerland) can be dated to the Neolithic remains to be clarified (there are no ${ }^{14} \mathrm{C}$ data directly from the ard furrows; Rageth, 1992; Rageth and Defuns, 1992).

We do not know if weeding was practised. We can only assume it was carried out, based on assumptions and comparisons with, for example, present-day organic farming. As for harvesting techniques, we can take the growth heights of the weed taxa as an indicator, assuming that most of the weeds were harvested with the cereals. If weed seeds appear in stocks it is highly likely that they were harvested with the cereals; this is well known from ethnographic sources. Therefore, in archaeobotany, the height of the weeds is usually taken as an indication of the height of the harvest. If we can find large quantities of very low growing weeds (e.g. Aphanes arvensis), it is highly probable that cereals (for example) were cut very close to the ground. If we can only find high growing weeds, the culms were cut at some distance from the ground, and low growing weeds could not be harvested. In LN stocks, low growing weeds are generally present, so we must assume that harvest height was usually quite close to the ground.

\section{Which proportion of the weeds is represented in storage contexts?}

Undoubtedly the best basis for reconstructing the weed flora in LN times is the spectrum of wild plants appearing in storage contexts representing single events (the so-called closed assemblages). There are many different kinds of such storage contexts represented in lakeshore settlements, from ears stored in an uncleaned state to very well cleaned stocks in which only grains are present. A systematic evaluation of the cleaning stages of these stocks, based on the ethnographic data mentioned above, is unfortunately missing. Moreover, we cannot always exclude secondary mixing of materials during a conflagration when houses collapsed. Nevertheless, uncleaned or only party cleaned stocks are known from several settlements (see Figure 5 in the print text and OSM Table 5; e.g. Maier, 2001; Brombacher and Jacomet, 2003). In these, seeds of annual weeds in today's sense are regularly present, although in very different amounts (from zero to 15 taxa, from zero to more than 100 remains). There are however also a series of other taxa present in the stocks; these taxa are considered today to be ruderals, grassland plants, plants of woodland clearings etc.; in Neolithic times they must 
have been weeds too (see Figure 5 in the print text and OSM Table 5: 1-8 taxa and 0-50 remains; see tables in Brombacher and Jacomet, 1997, pp. 258-261; OSM Table 5).

Beside annuals perennials were also regularly present. The same - incidentally holds true for the LBK fields of the loess landscapes (Kreuz and Schäfer, 2011), and is shown on Figure 5 in the print text and in OSM Table 5. The spectrum of wild plants known from storage contexts representing single events is eminently comparable with 'weedy' wild plant spectra in mixed samples (see Figure 5 in the print text and OSM Table 5).

One so far not mentioned reason for the difficulties to compare modern weed communities with Neolithic ones is that not all of today's weed species (the anthropochores) were present in Central Europe at the time (see e.g. Willerding, 1986; Jacomet and Brombacher, 2009; Kreuz, 2012) and therefore many opportunistic 'weedy' taxa, which today are more typical of forest fringes etc., had also spread onto the fields.

\section{Results of on-site data: Evaluation of the weed spectra based on their life forms, other functional attributes and ecological demands}

For an overview of 'traditional' evaluations based on ecological groups, life forms and Ellenberg indicator values (Ellenberg, 1991) we refer to Brombacher and Jacomet (1997, p. 256 ff.), Maier (2001) and Hosch and Jacomet (2004, p. 128 ff.). More recently, a novel type of evaluation method for weeds was introduced, the FIBS-approach (Functional Interpretation of Botanical Surveys) (see e.g. Jones (2002), Bogaard (2004), Bogaard (2011) and Bogaard et al. (2016)). 'This alternative approach uses functional attributes, which measure the ecological characteristics of weed species, and is not dependent on the co-occurrence of particular species or the reliability of field observations to indicate species preferences. Functional attributes permit the 'translation' of present-day ecological data to archaeobotanically attested species and, through an understanding of ecological processes, provide the means to disentangle the separate effects of different husbandry practices, so allowing the identification of novel combinations of practices in the past' (from Jones, 2002). FIBS was applied to assemblages from two sites only: the burnt cereal (mainly tetraploid naked wheat) stock layer of the settlement of Hornstaad-Hörnle IA (3910 cal. BC) and a similar layer containing a store of emmer from the settlement of ZurichMythenschloss dating to the period of the Corded Ware culture (around $2700 \mathrm{cal}$. 
BC; Brombacher and Jacomet, 1997).

The most important results are briefly presented in the print text.

Hints on grazing the fallows

In the region of Zurich, one of the best investigated lakeshore areas, the weed spectrum shows an increase in the presence of plants growing on present-day grassland in the course of the LN (Figure OSM 5). This points to grazing the fallows or the stubble fields, which had the side-effect of manuring them (the same was noticed already in the early Neolithic LBK (LBK phase I to phase II; Kreuz, 2012). This also means that some parts of the landscape remained open for longer periods and suggests that there was a permanent and steady pressure on such places from both humans and animals. Here, but perhaps also in the floodplains, the first grassland plant communities may have developed during the third millennium cal. BC, in parallel with larger herd sizes (Figure OSM 2). This grassland is however not yet directly comparable with modern sown, manured and irrigated grassland.

\section{Results of on-site data indicating opening the landscape for pastures and hunting/gathering grounds}

Evidence based on denrotypology (types of woodland management)

By analysing large masses of timber used for building from the lakeshore villages it has become increasingly clear how dynamic the settlement pattern during the LN usually was: settlement phases were generally short (mostly five to seventeen years; for an overview see Bleicher, 2009, pp. 144-152). Longer settlement durations are documented only exceptionally. Often, the settlements move around within a certain region. Bleicher (2009) has reconstructed ten-year cycles of woodland management ('Freistellungsreaktionen und Stockwaldphasen') in two settlement areas in the surroundings of lake Federsee in Upper Swabia. There are, however, also locations to which people always came back, and therefore these regions were settled continuously for over 1000 years with only a few decades of interruption (like the Zurich region or Sipplingen on Lake Constance)

In some time periods young wood from coppices of managed woodland with short rotations of 10-20 years was used for building purposes. Abrupt growth changes in young oak tree ring series reflect successive coppice rotations (as seen for instance in the hinterland of Sipplingen on Lake Constance). On the other hand, in 
some periods (after longer breaks in settlement activity) natural forest stands with old-grown trees were felled, as at the beginnings of the Pfyn and Horgen cultural sequences in the western part of the region around Lake Constance (see Figure OSM 1 for chronology). There are clear indications that the settlements at the lake's shore were part of a larger system involving the hinterland where settlement occupation must have existed too (although very little is known of such occupation). In the final phases of the exploitation cycles there might be signs of land overuse and woodland degradation, especially towards the end of the Neolithic (e.g. Corded Ware phases in the western part of Lake Constance, although not visible in the $\mathrm{N}$ isotope record; see Styring et al., 2015).

For more details we refer to the recent compilation by Billamboz (2014) for the western part of Lake Constance, the supra-regional overview of Bleicher (2009, pp. 144-152) and to Suter and Francuz (2010) for the state of the art in western Switzerland. Ongoing analyses in the Zurich region show similar trends (Bleicher et al., 2013).

To conclude, there were evidently sophisticated cycles of woodland use in existence. A mosaic-like landscape in areas used for timber, but also as a source of leafy hay, pasture and wild fruits (see below) can be reconstructed (for an ethnographic example see Figure OSM 6).

\section{Evidence based on ruminant dung}

In wetland settlement layers, animal dung, mostly of ruminants (sheep/goat and cattle) is very often encountered (a very good example is shown on Figure 6 in the print text). It therefore seems clear that ruminants were kept inside the settlements, at least some of the time, for example for milking. It also shows that there was at least some dung available, but its use cannot be reconstructed directly. Investigations of plant macro- and micro-remains (mainly pollen) in ruminant dung gave valuable indications on the surfaces on which the animals grazed (see Rasmussen, 1989; Rasmussen, 1993; own investigations include Akeret and Jacomet, 1997; Akeret et al., 1999; Akeret and Rentzel, 2001; Haas, 2004; Kühn and Hadorn, 2004; Kühn and Wick, 2010; Marinova et al., 2013; Kühn et al., 2013). So far mainly dung of small ruminants, goat and sheep, has been investigated (it is in fact indistinguishable). Two examples are shown on Figures $7 \mathrm{a}$ and $7 \mathrm{~b}$ in the print text which are explained here more in detail: Figures $7 \mathrm{a}$ and $7 \mathrm{~b}$ include only the major taxa (i.e. quantitatively and/or ecologically significant), among them all the taxa with macrofossil finds. Pollen, 
spores, stomata, and fern sporangia are shown as percentages, related to the total sum of pollen and Pteridophyta spores. Pollen and micro-charcoal concentrations are given as grains or particles per mg of wet material. In order to facilitate the comparison of the micro- and macrofossil remains, the macroremains (dots, indicating presence/absence) are combined with the respective pollen taxa (bars) in the diagrams. The pollen taxa are summarized into groups representing different habitats (woodland, open land etc.) or fodder types (e.g. evergreen trees). The samples are arranged according to their pollen assemblages; the pollen assemblage groups (PAGs) represent different fodder types or natural habitats, respectively.

Figure 7a (print text): Pollen and macroremain diagram of Egolzwil 3 (Late Neolithic, 4260 cal. BC). 32 pellets were investigated for both, macroremains and pollen resp. microcharcoal.

Plant macroremains: Trees/shrubs are represented by regular finds of Rosa/Rubus prickles, leaf epidermis of Hedera helix and anthers of Corylus avellana. Fruits of Rubus, leaf epidermis of Abies alba, Viscum album and Quercus were found in lower frequencies. Herbs are represented by single finds of seeds/fruits or epidermis of a larger number of taxa, growing today on open land, ruderal and/or wet habitats (along ditches or in marshy areas). Cultivars are mainly represented by high quantities of Triticum testa. Remains of other cultivars were found in only small amounts.

Microremains: The pollen concentrations are generally high. Nearly all dung samples contained high amounts of micro-charcoal. The pollen spectra were divided into three pollen assemblage groups (PAG): PAG EGW-1 (13 samples; No. $1 / 2$ to 2/2) shows a dominance of Corylus and/or Alnus, accompanied by woodland geophytes flowering in early spring. PAG EGW-2 (10 samples, No. 1/17 to $4 / 2$ ) shows high percentages of Poaceae pollen in combination with taxa from woodland edges and open woodland like Rosa, Rubus, Galeopsis, and Hypericum perforatum type. PAG EGW-3 (9 samples, No. 3/16 to 4/9) is characterised by taxa growing in fresh and/or rather open woodland habitats, such as Humulus lupulus, Impatiens, Galeopsis, and Pteridophyta. Cereal pollen was found in most of the samples.

Figure 7b (print text): Pfäffikon Burg (Late Neolithic, 3100 cal. BC). 52 pellets were investigated for both, macroremains and pollen resp. microcharcoal. 
Plant macroremains: Phanerophytes are represented by continuously occurring prickles of Rosa/Rubus, fruits of Rubus as well as regular finds of leaf epidermis of Abies alba and Hedera helix. Other trees/shrubs are rare (not shown on the diagram). Herbs of open land and/or fresh habitats are represented only by a rather small number of taxa, occurring in low frequencies. Remains of cultivars however are frequent, especially Triticum testa and flax remains. Sporangia of ferns were also found regularly.

Microremains: The pollen concentrations are generally high. Nearly all the samples show high quantities of micro-charcoals. The pollen spectra were assigned to five PAGs, pointing to a great variety of fodder sources in the landscape: PFB-1 (9 samples, No. 369/11 to 363/31) is dominated by Salix and Corylus avellana, with herbaceous taxa indicating grazing in open woodland and wetland, such as Pteridophyta and Cyperaceae. Pollen values of deciduous trees are generally low. PFB-2 (15 samples, No. 363/23 to 409/6) is characterised by very high percentages of Poaceae, accompanied by shrubs and herbs representing woodland edges, coppices and open land areas; other non-arboreal pollen (NAP) are rare. In PFB-3 (10 samples, No. 391/3 to 409/07) rather high percentages of mesophilous deciduous trees are combined with Abies alba pollen and stomata, and various amounts of Corylus, Alnus, and Betula. Among the NAP, Pteridophyta, Allium ursinum t., Ranunculus acris t., Anthriscus sylvestris, and Cyperaceae show higher values. PFB-4 (11 samples, No. 409M/2 to 363/4) shows a strong dominance of either Pteridophyta spores or shrub pollen (Rosa, Rubus) representing open woodland habitats. Ranunculus acris t. and Anthriscus sylvestris belong to the most frequent herb taxa. PFB-5 (7 samples, No. 363/5 to 363/16) is very poor in tree pollen and dominated by plants growing on fields and ruderal places, such as Artemisia, Papaver rhoeas t., and Triticum t. The lowermost sample 363/16 with the highest amount of Cerealia-type pollen contains only a low percentage of charcoal.

Evidence based on open-land-taxa (grassland, woodland edges etc.) In general, we can see an increase in diversity but also the ubiquitous presence of open-land taxa in the course of the LN (see examples in Brombacher and Jacomet, 1997). Not only has the weed flora become more diverse (see above) but also other open-land communities have become more widespread. Domestic animals play once again an important role in this context. In the dung pieces mentioned above, there is much evidence for winter- and summer grazing and foddering of 
the ruminants in the vicinity of the settlement (see previous chapter for references). This is corroborated by the insect data (e.g. Lemdahl, 2004; Schmidt, 2011). There must have been quite extensive, heavily pastured surfaces close to the settlements. An attempt to model the grazing pressure based on the minimum number of individuals (MNI) of domestic animals at the settlement of ArbonBleiche 3 (around 3380 cal. BC) sows that 5-10 (minimum 2, maximum 13) km² around the settlement were needed to provide enough fodder for the herd (Jacomet et al., 2004, p. 399; for modelling attempts in the Zurich region see Ebersbach, 2003). There was, however, no grassland in today's sense in the LN. First grassland plant communities used for pastures and haymaking resembling modern grassland communities did not exist before the Late Bronze Age or even the Late Iron Age in Central Europe (see e.g. Körber-Grohne, 1990; Körber-Grohne, 1993; Willerding, 1999; Kreuz, 2005, p. 174 ff.; Jacomet and Brombacher, 2009, and fig. 5 there).

On what surfaces then did the animals browse? In the course of the LN we see an increase in the ubiquitous presence of some grassland taxa (macroremains; Figure OSM 5 shows 4 taxa as examples of the general trend.

It is mainly during the third millennium cal. $\mathrm{BC}$ that some kind of grassland-like plant communities became more important. This is corroborated by on-site pollen studies from the region of Zurich (Erny-Rodmann, 1995). However, whether these taxa really grew on grassland in today's sense, or were established, for instance, on grazed short-fallows or in open woodlands, is difficult to ascertain (another possibility may be beaver meadows in floodplains). Some of the taxa obviously grew on fields and fallows as the weed spectra show. In any case, this development goes hand in hand with increasing cattle herd sizes, which can be reconstructed on the basis of data from bone concentrations in occupation layers (Figure OSM 2; (Schibler et al., 1997: Synthesis) and is most probably a result of a rising grazing pressure that reached its maximum during the Corded Ware phases from $2800 \mathrm{cal}$. $\mathrm{BC}$ onwards. An intensification of woodland management practices like coppicing also played a role (see above). The appearance in the macroremain record of thorny plant species like juniper (Juniperus) or holly (Ilex), which became more widespread under high pasture pressure towards the later phases of the LN, is in good agreement with these observations (Brombacher and Jacomet, 1997, p. 277, table D359; corroborated by ongoing analyses in the Zurich region).

Off-site pollen data from the Mainau site (western Lake Constance) show rising micro-charcoal values in these periods (Figure 9 in the print text); this can be 
interpreted as a need to expand grazing areas by burning. The latter would support our contention that fire played a crucial role in shaping a more open landscape in the course of the LN.

\section{Evidence based on gathering and hunting}

In well-investigated LN settlement layers we can find over 100 species of wild plants, and most of them were useful in one way or another (see e.g. Jacomet et al., 1989; Antolin et al., 2015 [in press]). Not only did food for humans have to be provided by gathering, but also fodder (and pasture) for animals, and wood for constructions and firewood (for the latter see e.g. Dufraisse, 2008), as well as bast fibres etc. (as an example see Jacomet et al., 2004: Synthesis). Human food in the form of fruits rich in starch and fat (like hazelnuts, acorns and beechnuts) and vitamins (like rose hips, raspberries, wild strawberries, crab apples) appears in huge quantities in LN settlement layers. The waterlogged preservation of the layers is one of the reasons why gathered fruits are so well represented in lakeshore settlements (Jacomet, 2013; Colledge and Conolly, 2014). There is plenty of evidence that such fruits were indeed eaten because human faeces rich in such fruits are documented (see e.g. Maier, 2001). Some are also found in crusts inside pots: they were cooked.

It is however hard to quantify what proportion of the calories was provided by hunted and gathered food. On the basis of a well-sampled, recently-investigated cultural layer from Zürich Parkhaus-Opéra (layer 13; the dendrochronological dating indicates that the village was occupied for just over twenty years from 3176 to 3153 cal. BC; Bleicher and Harb, 2015 [in press]), we think that gathered foods in the nutrition could have provided up to $20 \%$ of the calories (Figure OSM 7; Antolin et al., 2015 [in press]). Accumulations of gathered food, e.g. hazelnut shells, were also present in the rubbish heaps of Zürich Parkhaus-Opéra (layer 13). This and many examples from other LN wetland settlements show that hazelnuts were always important in the nutrition. At Hornstaad-Hörnle I the settlement including the whole of that year's harvest burnt down in 3910 cal. BC (Maier, 2001); in the layer directly above this burnt layer there is a layer full of hazelnut shells, which suggests that hazelnuts also served as an important staple in times of need. In 
many settlements there are stocks with gathered plants (e.g. Gachnang-Niederwil or Hornstaad-Hörnle 1A; van Zeist and Boekschoten-van Helsdingen, 1991; Maier, 2001). We can even put forward the hypothesis that fruit-bearing shrubs and trees (and probably also valuable annuals; Schlichtherle, 1981) were tended to achieve higher productivity. It would otherwise not have been possible to collect their fruits in large amounts, as represented by tens of thousands of remains (for details see Antolin et al., 2015 [in press]). In addition to providing calories gathered plants also had the important role of providing vitamins and microelements (see Kreuz, 2012).

In order to create landscapes suitable for a good yield in gathered wild plants we consider opening and keeping the landscapes open by burning to be a good strategy. This hypothesis is well supported by ethnographic sources. Burning was widespread to create good gathering grounds, e.g. among Native North American forest communities which in some ways were intermediate between farmers and hunter-gatherers (see Smith's 2001 'low level food production'; or 'niche construction', e.g. Kendal et al., 2011; Smith, 2011a). For more examples from different parts of the world we refer to Scherjon et al. (2015). It must however be borne in mind that burning the landscape is a characteristic of hunter-gatherer groups whereas the LN communities were clearly farmers.

Burning may also have played an significant part in creating better hunting and browsing grounds since in several phases of the LN, hunting was important for the provision of food (Schibler, 2016 [in press]). This may hold for whole settlements or only for parts of them as investigations in Arbon-Bleiche 3, for example, have shown for the period around 3380 cal. BC (Deschler-Erb and Marti-Grädel, 2004). Good hunting grounds in the surroundings of the settlements must indeed have been of crucial importance. Larger areas of open land and a well-structured landscape are also the reason why animals like hare or red fox become increasingly important in the course of the LN (mean percentages of bones rise from almost zero to well above 2-3\% or even more; see figs. 10 and 11 in Jacomet and Schibler 2006). 


\section{Results of off-site data concerning opening the landscape and landscape management}

The woodland in the western part of Lake Constance was dominated by Fagus sylvatica and other broad-leaved trees like Quercus, Tilia, Ulmus or Acer (e.g. Rösch 2013; Rösch et al., 2014; Lechterbeck, 2013; Lechterbeck et al., 2014). During landuse phases of the fourth and early third millennium cal. BC, several phases in which Fagus decreased strongly are visible in the many high-resolution pollen diagrams from there. In parallel there is an increase in secondary forest elements such as Corylus and Betula. This is interpreted as a replacement of the Fagusdominated woodland by semi-open/shrubby vegetation, probably also coppiced forests, at the beginning of the LN. At the same time an increase of micro-charcoal (fluctuating curves) indicates woodland burning. During the strongest land-use phases of the LN, the natural woodland was in some places almost completely replaced by shrubs and coppiced forest; there are cases where the Fagus pollen curve declines from more than $30 \%$ to less than $10 \%$, and a decrease in Tilia and Ulmus is also visible. The Quercus curve does not show such fluctuations, possibly because some oak trees were tended for a good yield in acorns.

Human impact is clearly visible in regions where settlements are located nearby (Lechterbeck et al., 2014, p. 109, mentions the Hornstaad and Mainau profiles). NAP and cereals also occur in higher values (Figure 9 in the print text). When settlements are located further away such impact is less visible (described as short episodes of forest disturbances with compensation by secondary forest elements namely hazel and birch). Although agriculture is indicated by cereal pollen, a large increase of NAP and especially Plantago lanceolata is not recorded (as in the Luttersee profile near an Early Neolithic LBK settlement near Göttingen or in the later Corded Ware and Bell Beaker phases in the western Lake Constance region). Cereal pollen is usually rare. All this is interpreted as follows: extensive open land such as grazed forests, pastures, meadows or fallow land with strong pollen emissions of Poaceae, Plantago lanceolata and other wind-pollinated herbs did not exist.

An attempt by Lechterbeck (2013) to apply the models developed by the POLLANDCAL network (Sugita, 2007a; Sugita, 2007b; Gaillard et al., 2010) to reconstruct quantitatively the land cover for the western Lake Constance region in the older phase of the LN (4200-3700 cal. BC) on the basis of the results from two small lakes, Buchensee and Steisslinger See (the latter in the Hegau, more than 20 
$\mathrm{km}$ to the west of Lake Constance) is not further considered here as the results concerning woodland/shrubby vegetation cover do not differ from the effects mentioned above. In addition, only one model (the slash-and-burn model) was used to reconstruct the land use and the results are therefore unbalanced.

\section{References}

Akeret Ö, Haas JN, Leuzinger U, et al. (1999) Plant macrofossis and pollen in goat/sheep faeces from the Neolithic lake-shore settlement Arbon Bleiche 3, Switzerland. The Holocene 9(2): 175-182.

Akeret Ö and Jacomet S (1997) Analysis of plant macrofossils in goat/sheep faeces from the Neolithic lake shore settlement of Horgen Scheller - an indication of prehistoric transhumance? Vegetation History and Archaeobotany 6(4): 235-239.

Akeret Ö and Rentzel P (2001) Micromorphology and plant macrofossil analysis of cattle dung from the neolithic lake shore settlement of Arbon-Bleiche 3. Geoarchaeology 16(6): 687-700.

Antolin F, Bleicher N, Brombacher C, et al. (2015 [in press]) Quantitative approximation to large-seeded wild fruit use in a late Neolithic lake dwelling. The case study of layer 13 of Parkhaus Opéra in Zürich (Central Switzerland). Quaternary International doi: 10.1016/j.quaint.2015.08.003.

Antolin F, Brombacher C, Kühn M, et al. (2016 [in press])Archäobotanische Untersuchungen der Horgen-zeitlichen Siedlungen von Zürich Parkhaus Opéra. In: Bleicher N and Harb C (eds) Zürich Parkhaus Opéra: Wirtschaft und Umwelt. Zürich.

Antolin F, Steiner BL, Vach W, et al. (2015) What is a litre of sediment? Testing volume measurement techniques for wet sediment and their implications in archaeobotanical analyses at the Late Neolithic lake-dwelling site of Parkhaus Opera (Zürich, Switzerland). Journal of Archaeological Science 61: 36-44.

Behre K-E and Jacomet S (1991) The ecolocical interpretation of archaeobotanical data. In: van Zeist WA, Wasylikowa K and Behre K-E (eds) Progress in Old World Palaeoethnobotany. Rotterdam: Balkema, 81-108.

Billamboz A (2014) Regional patterns of settlement and woodland developments: Dendroarchaeology in the Neolithic pile-dwellings on Lake Constance (Germany). The Holocene 24(10): 1278-1287.

Binford LR and Binford SR (1968) New Perspectives in Archaeology, Chicago. 
Bleicher N (2009) Altes Holz in neuem Licht. Archäologische und dendrochronologische Untersuchungen an spätneolithischen Feuchtbodensiedlungen in Oberschwaben, Stuttgart: Konrad Theiss Verlag.

Bleicher N, Bolliger M and Gut U (2013) Ein erster dendrotypologischer Überblicksversuch über die Bauholzserien der Ufersiedlungen am Zürichsee. In: Bleicher N, Gassmann P, Martinelli N, et al. (eds) Dendro. Chronologie Typologie Ökologie. Festschrift für André Billamboz zum 65. Geburtstag. 1. Auflage ed. Janus-Verlag: Freiburg im Breisgau, 51-57.

Bleicher N and Harb C (2015 [in press]) Zürich-Parkhaus Opéra. Eine neolithische Feuchtbodensiedlung. Band 1. Befunde, Schichten und Dendroarchäologie. Mongraphien der Kantonsarchäologie Zürich, Zürich und Egg: Fotorotar.

Bleicher N and Ruckstuhl B (2015 [in press]) Die archäologischen Befunde. In: Bleicher N and Harb C (eds) Zürich-Parkhaus Opéra. Eine neolithische Feuchtbodensiedlung. Band 1. Befunde, Schichten und Dendroarchäologie. Mongraphien der Kantonsarchäologie Zürich, Zürich und Egg: Fotorotar.

Bleicher N and Schubert E (2015) Why are they still there? A model of accumulation and decay of organic prehistoric cultural deposits. Journal of Archaeological Science 61: 277-286.

Bogaard A. (2002) Questioning the relevance of shifting cultivation to Neolithic farming in the loess belt of Europe: evidence from the Hambach Forest experiment. Vegetation History and Archaeobotany 11(1-2): 155-168.

Bogaard A. (2004) Neolithic Farming in Central Europe. An archaeobotanical study of crop husbandry practices, London: Routledge.

Bogaard A. (2011) Farming practice and society in the central European Neolithic and Bronze Age: an archaeobotanical response to the secondary products revolution model. In: Hadjikoumis A, Robinson E and Viner S (eds) The Dynamics of Neolithisation in Europe. Studies in honour of Andrew Sherratt. Oxford: Oxbow Books, 266-283.

Bogaard A (2012) Middening and Manuring in Nelithic Europe: Issues of Plausibility, Intensity and Archaeological Method. In: Jones R (ed) Manure Matters. Historical, Archaeological and Ethnographic Perspectives. Farnham, Surrey: Ashgate Publishing Ltd., 25-39.

Bogaard A, Fraser R, Heaton THE, et al. (2013) Crop manuring and intensive land management by Europe's first farmers. Proceedings of the National Academy of Sciences of the United States of America 110(31): 12589-12594.

Bogaard A, Hodgson J, Nitsch E, et al. (2016) Combining functional weed ecology and crop stable isotope ratios to identify cultivation intensity: a comparison 
of cereal production regimes in Haute Provence, France and Asturias, Spain. Vegetation History and Archaeobotany 25: 57-73.

Bogaard A and Outram AK (2013) Palaeodiet and beyond: stable isotopes in bioarchaeology. World Archaeology 45(3): 333-337.

Brombacher C and Jacomet S (1997) Ackerbau, Sammelwirtschaft und Umwelt: Ergebnisse archäobotanischer Untersuchungen. In: Schibler J, HüsterPlogmann H, Jacomet S, et al. (eds) Ökonomie und Ökologie neolithischer und bronzezeitlicher Ufersiedlungen am Zürichsee. Ergebnisse der Ausgrabungen Mozartstrasse, Kanalisationssanierungen Seefeld, AKAD/Pressehaus und Mythenschloss in Zürich. Monographien der Kantonsarchäologie Zürich 20, Zürich und Egg: Direktion der öffentlichen Bauten des Kantons Zürich, 220279.

Brombacher C and Jacomet S (2003) Ackerbau, Sammelwirtschaft und Umwelt. In: Zwahlen H (ed) Die jungneolithische Siedlung Port-Stüdeli. Ufersiedlungen am Bielersee 7, Bern: Paul Haupt Verlag, 66-86.

Broström A, Nielsen AB, Gaillard M-J, et al. (2008) Pollen productivity estimates of key European plant taxa for quantitative reconstruction of past vegetation: a review. Vegetation History and Archaeoabotany 17(5): 461-478.

Colledge S and Conolly J (2014) Wild plant use in European Neolithic subsistence economies: a formal assessment of preservation bias in archaeobotanical assemblages and the implications for understanding changes in plant diet breadth. Quaternary Science Reviews 101(0): 193-206.

Davis SJM (1987) The Archaeology of Animals, London: B. T. Batsford.

Deschler-Erb S and Marti-Grädel E (2004) Viehhaltung und Jagd - Ergebnisse der Untersuchung der handaufgelesenen Tierknochen. In: Jacomet S, Leuzinger U and Schibler J (eds) Die jungsteinzeitliche Seeufersiedlung Arbon-Bleiche 3: Umwelt und Wirtschaft. Archäologie im Thurgau 12, Frauenfeld: Amt für Archäologie des Kantons Thurgau, 158-252.

Dick M. (1989) Wirtschaft und Umwelt cortaillod- und horgenzeitlicher Seeufersiedlungen in Zürich (Schweiz). Ergebnisse samenanalytischer Untersuchungen aus der prähistorischen Station Mozartstrasse. Dissertationes Botanicae 132, Berlin / Stuttgart: J. Cramer, 114 p.

Dufraisse A (2008) Firewood management and woodland exploitation during the late Neolithic at Lac de Chalain (Jura, France). Vegetation History and Archaeobotany 17: 199-210. 
Ebersbach R (2002) Von Bauern und Rindern. Eine Ökosystemanalyse zur Bedeutung der Rinderhaltung in bäuerlichen Gesellschaften als Grundlage zur Modellbildung im Neolithikum, Basel: Schwabe Verlag.

Ebersbach R (2003) Paleoecological reconstruction and calculation of calorie requirements at lake Zurich, Switzerland. Landschaftsarchäologie und Geographische Informationssysteme: Prognosekarte, Besiedlungsdynamik und prähistorische Raumordnungen = The Archaeologiy of Landscpes and Geographic Information Systems: Predictive Maps, Settlement Dynamics and Space and Territory in Prehistory. Symposium 15.-19. Oktober 2001 Wünsdorf, Land Brandenburg. Archäoprognose I. Wünsdorf: Publikationen des Brandenburgischen Amtes für Denkmalpflege und Archäologischen Landesmuseums, 69-88.

Ehrmann 0, Biester H, Bogenrieder A, et al. (2014) Fifteen years of the Forchtenberg experiment-results and implications for the understanding of Neolithic land use. Vegetation History and Archaeobotany 23(1): 5-18.

Ellenberg H. (1991) Zeigerwerte der Gefässpflanzen Mitteleuropas (3. Auflage), Göttingen.

Erny-Rodmann C (1995) Von der Urlandschaft zur Kulturlandschaft. Pollenanalytische Untersuchungen an drei Uferprofilen aus dem Zürcher 'Seefeld' zu anthropogenen Vegetationsveränderungen seit dem Mesolithikum, PhD Thesis, Basel University.

Gaillard MJ, Sugita S, Mazier F, et al. (2010) Holocene land-cover reconstructions for studies on land cover-climate feedbacks. Climate of the Past 6(4): 483499.

Gross E, Jacomet S and Schibler J. (1990) Stand und Ziele der wirtschaftsarchäologischen Forschung an neolithischen Ufer- und Inselsiedlungen im Unteren Zürichseeraum (Kt. Zürich, Schweiz). In: Schibler J, Sedlmeier J and Spycher H (eds) Festschrift für Hans R. Stampfli. Beiträge zur Archäozoologie, Archäologie, Anthropologie, Geologie und Paläontologie. Basel: Helbing \& Lichtenhahn, 77-100.

Haas JN. (2004) Mikroskopische Analyse von Schaf-/ Ziegenkoprolithen. In: Jacomet S, Leuzinger U and Schibler J (eds) Die neolithische Seeufersiedlung Arbon Bleiche 3. Umwelt und Wirtschaft. Archäologie im Thurgau 12, Frauenfeld: Amt für Archäologie des Kantons Thurgau, 351-357.

Hellmann S, Bunting MJ and Gaillard M-J (2009) Relevant source area of pollen in patchy cultural landscapes and signals of anthropogenic disturbance in the pollen record. Review of Palaeobotany and Palynology 153: 245-258. 
Herbig C (2006) Archaeobotanical investigations in a settlement of the Horgener culture (3300 BC) 'Torwiesen II' at Lake Federsee, southern Germany. Environmental Archaeology 11(1): 131-142.

Herbig C (2009) Recent archaeobotanical investigations into the range and abundance of Neolithic crop plants in settlements around Lake Constance and in Upper Swabia (south-west Germany) in relation to cultural influences. Journal of Archaeological Science 36: 1277-1285.

Hillman GC (1984) Interpretation of archaeological plant remains: the application of ethnographic models from Turkey. In: van Zeist WA and Casparie WA (eds) Plants and Ancient Man. Rotterdam: Balkema, 1-41.

Hosch S and Jacomet S (2004) Ackerbau und Sammelwirtschaft. Ergebnisse der Untersuchung von Samen und Früchten. In: Jacomet S, Schibler J and Leuzinger U (eds) Die neolithische Seeufersiedlung Arbon Bleiche 3: Wirtschaft und Umwelt. Archäologie im Thurgau 12, Frauenfeld: Amt für Archäologie des Kantons Thurgau, 112-157.

Hosch S and Zibulski P (2003) The influence of inconsistent wet-sieving procedures on the macroremains concentration in waterlogged sediments. Journal of Archaeological Science 30: 849-857.

Hüster Plogmann H (2004) Fischfang und Kleintierbeute - Ergebnisse der Untersuchung von Tierresten aus den Schlämmproben. In: Jacomet S, Leuzinger U and Schibler J (eds) Die jungsteinzeitliche Seeufersiedlung Arbon-Bleiche 3: Umwelt und Wirtschaft. Archäologie im Thurgau 12, Frauenfeld: Amt für Archäologie des Kantons Thurgau, 253-276.

Ismail-Meyer K, Rentzel P and Wiemann P. (2013) Neolithic lakeshore settlements in Switzerland: new insights on site formation processes from micromorphology. Geoarchaeology: An International Journal 28: 317-339.

Jacomet S (2006) Plant Economy of the Northern Alpine Lake Dwelling area 3500-2400 BC cal. Environmental Archaeology 11(1): 64-83.

Jacomet S (2007a) Plant Macrofossil Methods and Studies. Use in Environmental Archaeology. In: Elias SA (ed) Encyclopedia of Quaternary Science. Oxford: Elsevier, 2384-2412.

Jacomet S (2007b) Neolithic plant economies in the northern alpine foreland from 5500-3500 BC cal. In: Colledge S and Conolly J (eds) The Origins and Spread of Domestic Plants in Southwest Asia and Europe. Walnut Creek CA: Left Coast Press, 221-258.

Jacomet S (2008) Subsistenz und Landnutzung während des 3. Jahrtausends v. Chr. aufgrund von archäobotanischen Daten aus dem südwestlichen 
Mitteleuropa. In: Dörfler W and Müller J (eds) Umwelt - Wirtschaft Siedlungen im dritten vorchristlichen Jahrtausend Mitteleuropas und Südskandinaviens. Neumünster: Wachholtz Verlag, 355-377.

Jacomet S (2009) Plant economies and village life in Neolithic lake dwellings at the time of the Alpine Iceman. Vegetation History and Archaeobotany 18: 47-59. Jacomet S (2013) Archaeobotany: Analyses of Plant Remains from Waterlogged Archaeological Sites. In: Menotti F and O'Sullivan A (eds) The Oxford Handbook of Wetland Archaeology. Oxford: Oxford University Press, 497514.

Jacomet S (2014) Crop Diversity in Southwestern Central Europe from the Neolithic onwards In: Chevalier A, Marinova E and Pena-Chocarro L (eds) Plants and people: choices and diversity through time. Oxford: Oxbow Books, 82-95.

Jacomet S and Brombacher C (2005) Reconstructing intra-site patterns in Neolithic lakeshore settlements: The state of archaeobotanical research and future prospects. In: Della Casa P and Trachsel M (eds) WES'04 - Wetland Economies and Societies. Proceedings of the International Conference in Zurich, 10-13 March 2004. Zürich: Chronos, 69-94.

Jacomet S and Brombacher C (2009) Geschichte der Flora in der Regio Basiliensis seit 7500 Jahren: Ergebnisse von Untersuchungen pflanzlicher Makroreste aus archäologischen Ausgrabungen. Mitteilungen der Naturforschenden Gesellschaften beider Basel 11: 27-106.

Jacomet S, Brombacher C and Dick M (1989) Archäobotanik am Zürichsee. Ackerbau, Sammelwirtschaft und Umwelt von neolitischen und bronzezeitlichen Seeufersiedlungen im Raum Zürich. Ergebnisse von Untersuchungen pflanzlicher Makroreste der Jahre 1979-1988. Zürcher Denkmalpflege, Monographien 7, Zürich: Orell Füssli.

Jacomet S, Leuzinger U and Schibler J (2004) Synthesis. In: Jacomet S, Leuzinger U and Schibler J (eds) Die jungsteinzeitliche Seeufersiedlung Arbon - Bleiche 3. Umwelt und Wirtschaft. Archäologie im Thurgau 12, Frauenfeld: Amt für Archäologie des Kantons Thurgau, 381-416.

Jacomet S and Schibler J. (2006) Traction animale et données paléoenvironnementales au Néolithique dans le nord des Alpes. In: Pétrequin P, Arbogast R-M, Pétrequin A-M, et al. (eds) Premiers chariots, Premiers araires. La diffusion de la traction animale en Europe pendant les IVe et IIIe millénaires avant notre ère. Paris: CNRS EDITIONS, 141-156. 
Jacomet S and Schibler J (2010) Subsistenzwirtschaft aus archäo(bio)logischer In: Matuschik I, Strahm C, Eberschweiler B, et al. (eds) Vernetzungen. Aspekte siedlungsarchäologischer Forschungen. Festschrift für Helmut Schlichtherle zum 60. Geburtstag Freiburg im Breisgau: Lavori, 113-125.

Jones GEM (1987) A statistical approach to the archaeological identification of crop processing. Journal of Archaeological Science 14: 311-323.

Jones GEM (1990) The application of present-day cereal processing studies to charred archaeobotanical remains. Circaea 6(2): 91-96.

Jones GEM (2002) Weed ecology as a method for the archaeobotanical recognition of crop husbandry practices. Acta Palaeobotanica 42(2): 185-193.

Kaltenthaler D, Lohrer J, Kröger P, et al. (2015) OssoBook v5.2.4. München, Basel. (http://xbook.vetmeduni-muenchen.de/)

Kendal J, Tehrani JJ and Odling-Smee J (2011) Human niche construction in interdisciplinary focus Introduction. Philosophical Transactions of the Royal Society B-Biological Sciences 366(1566): 785-792.

Körber-Grohne U (1990) Gramineen und Grünlandvegetationen vom Neolithikum bis zum Mittelalter in Mitteleuropa. Bibliotheca Botanica 139, Stuttgart: E. Schweizerbart'sche Verlagsbuchhandlung.

Körber-Grohne U (1993) Urwiesen im Berg- und Hügelland aus archäobotanischer Sicht. In: Brombacher C, Jacomet S and Haas JN (eds) Festschrift Zoller. Beiträge zu Philosophie und Geschichte der Naturwissenschaften, Evolution und Systematik, Ökologie und Morphologie, Geobotanik, Pollenanalyse und Archäobotanik. Berlin / Stuttgart: J. Cramer, 453-468.

Kreuz A (1990) Searching for 'Single-Activity Refuse' in Linearbandkeramik Settlements. An Archaeobotanical Approach. In: Robinson DE (ed) Experimentation and Reconstruction in Environmental Archaeology. Oxford: Oxbow Books, 63-76.

Kreuz A (1995) On-site and off-site data - interpretative tools for a better understanding of Early Neolithic environments. In: Kroll H and Pasternak R (eds) Res archaeobotanicae. International Workgroup for Palaeoethnobotany, Proceedings of the 9th Symposium, Kiel 1992. Kiel: Oetker-Voges, 117-134.

Kreuz A (2005) Landwirtschaft im Umruch? Archäobotanische Forschungen zu den Jahrhunderten um Christi Geburt in Hessen und Mainfranken. Berichte der Römisch Germanischen Kommission 80: 97-292. 
Kreuz A (2012) Die Vertreibung aus dem Paradies? Archäobiologische Ergebnisse zum Frühneolithikum im westlichen Mitteleuropa. Bericht der RömischGermanischen Kommission 91(2010): 23-196.

Kreuz A, Märkle T, Marinova E, et al. (2014) The Late Neolithic Michelsberg culture - just ramparts and ditches? A supraregional comparison of agricultural and environmental data. Praehistorische Zeitschrift 89(1): 72-115.

Kreuz A and Schäfer E (2011) Weed finds as indicators for the cultivation regime of the early Neolithic Bandkeramik culture? Vegetation History and Archaeobotany 20(5): 333-348.

Kreuz A and Schäfer E (2014) Archäobotanisches Datenbankprogramm ArboDat 2013 Wiesbaden: Hessen Archäologie.

Kühn M and Hadorn P (2004) Pflanzliche Makro- und Mikroreste aus Dung von Wiederkäuern. In: Jacomet S, Leuzinger U and Schibler J (eds) Die jungsteinzeitliche Seeufersiedlung Arbon Bleiche 3. Umwelt und Wirtschaft. Archäologie im Thurgau 12, Frauenfeld: Amt für Archäologie des Kantons Thurgau, 327-350.

Kühn M, Maier U, Herbig C, et al. (2013) Methods for the examination of cattle, sheep and goat dung in prehistoric wetland settlements with examples of the sites Alleshausen-Täschenwiesen and Alleshausen-Grundwiesen (around 2900 BC) at Lake Federsee, south-west Germany. Environmental Archaeology 18(1): 43-57.

Kühn M and Wick L (2010) Pflanzenreste in Koprolithen von Schafen und Ziegen: Was frassen die kleinen Wiederkäuer von Pfäffikon-Burg? In: Eberli U (ed) Die horgenzeitliche Siedlung Pfäffikon-Burg. Monografien der Kantonsarchäologie Zürich 36. Zürich und Egg: Fotorotar, 256-261.

Lechterbeck J (2013) Evaluation of economic activity trhough palynological data: Medelling agricultural pressure onlandscape (REVEALS and LOVE). In: Kerig T and Zimmermann A (eds) Economic archaeology. From structure to performance in European archaeology. Bonn: Rudolf Habelt GmbH, 129-141.

Lechterbeck J, Kerig T, Kleinmann A, et al. (2014) How was Bell Beaker economy related to Corded Ware and Early Bronze Age lifestyles? Archaeological, botanical and palynological evidence from the Hegau, Western Lake Constance region. Environmental Archaeology 19(2): 95-113.

Lemdahl G (2004) Insect remains. In: Jacomet S, Leuzinger U and Schibler J (eds) Die jungsteinzeitliche Seeufersiedlung Arbon Bleiche 3. Umwelt und Wirtschaft. Archäologie im Thurgau 12, Frauenfeld: Amt für Archäologie des Kantons Thurgau, 365-371. 
Leuzinger U (2000) Die jungsteinzeitliche Seeufersiedlung Arbon Bleiche 3. Befunde, Archäologie im Thurgau 9, Frauenfeld: Amt für Archäologie des Kantons Thurgau.

Leuzinger U (2002) Holzartefakte. In: de Capitani A, Deschler-Erb S, Leuzinger U, et al. (eds) Die jungsteinzeitliche Siedlung Arbon Bleiche 3: Funde. Archäologie im Thurgau 11, Frauenfeld: Amt für Archäologie des Kantons Thurgau, 76114.

Maier U (2001) Archäobotanische Untersuchungen in der neolithischen Ufersiedlung Hornstaad-Hörnle IA am Bodensee. In: Maier U and Vogt $\mathrm{R}$ (eds) Siedlungsarchäologie im Alpenvorland VI. Botanische und pedologische Untersuchungen zur Ufersiedlung Hornstaad-Hörnle IA. Forschungen und Berichte zur Vor- und Frühgeschichte in Baden-Württemberg 74. Stuttgart: Konrad Theiss Verlag, 9-384.

Marinova E, Linseele V and Kühn M (2013) Bioarchaeological research on animal dung - possibilities and limitations (Editorial). Environmental Archaeology 18(1): 1-3.

Mauvilly M and Boisaubert J-L (2005) Entre terre et lacs dans les régions de Morat et d'Estavayer-le-Lac (FR) - quelle image après 30 ans de recherches assidues? In: Della Casa P and Trachsel M (eds) Wetland economies and societies. Zürich: Chronos Verlag, 179-184.

Pétrequin P, Magny M and Bailly M (2005) Habitat lacustre, densité de population et climat. L'exemple du Jura français. In: Della Casa P and Trachsel M (eds) WES'04. Wetland Economies and Societies. Proceedings of the International Conference Zurich, 10-13 March 2004. Zürich: Chronos, 143-168.

Rageth J (1992) Chur - Areal Ackermann, jungsteinzeitliche Siedlungsreste und Spuren eines Pflugackerbaus. Archäologie in Graubünden: 31-36.

Rageth J and Defuns A (1992) Castaneda - Pian del Remit, jungsteinzeitliche Siedlungsreste und Pflugspuren. Archäologie in Graubünden: 37-42.

Rasmussen P (1989) Leaf-foddering of livestock in the Neolithic: Archaeobotanical evidence from Weier, Switzerland. Journal of Danish Archaeology 8: 51-71.

Rasmussen P (1993) Analysis of goat/sheep faeces from Egolzwil 3, Switzerland: Evidence for branch and twig foddering of livestock in the Neolithic. Journal of Archaeological Science 20: 479-502.

Rösch M (2013) Land use and food production in Central Europe from the Neolithic to the Medieval period: change of landscape, soils and agricultural systems according to archaeobotanical data. In: Kerig T and Zimmermann A 
(eds) Economic Archaeology: From Structure to Performance in European Archaeology. Bonn: Habelt Verlag, 109-128.

Rösch M, Ehrmann O, Herrmann L, et al. (2002) An experimental approach to Neolithic shifting cultivation. Vegetation History and Archaeobotany 11(12): 143-154.

Rösch M, Kleinmann A, Lechterbeck J, et al. (2014) Botanical off-site and on-site data as indicators of different land use systems: a discussion with examples from Southwest Germany. Vegetation History and Archaeobotany 23(1): 121-133.

Scherjon, Fulco, Bakels C, MacDonald K, et al. (2015) Burning the Land. An Ethnographic Study of Off-Site Fire Use by Current and Historically Documented Foragers and Implications for the Interpretation of Past Fire Practices in the Landscape Current Anthropology 56: on-line, June 2015.

Schibler J. (1997) Haus- und Wildtiernutzung in den jungsteinzeitlichen Feuchtbodensiedlungen des Kantons Thurgau. Archäologie der Schweiz 20(2): 57-61.

Schibler J (1998) OSSOBOOK, a database system for archaeozoology. In: Anreiter P, Bartosiewicz L, Jerem E, et al. (eds) Man and the animal world. In memoriam Sandor Bököny. Budapest, 491-510.

Schibler J (2006) The economy and environment of the 4th and 3rd millennia BC in the northern Alpine foreland based on studies of animal bones. Environmental Archaeology 11(1): 49-64.

Schibler J (2016 [in press]) Zooarchaeological results from Neolithic and Bronze Age wetland and dryland sites in the Central Alpine Foreland: Economic, ecologic and taphonomic relevance. In: Albarella U (ed) Oxford Handbook of Zooarchaeology. Oxford: Oxford University Press.

Schibler J, Hüster-Plogmann H, Jacomet S, et al. (1997) Ökonomie und Ökologie neolithischer und bronzezeitlicher Ufersiedlungen am Zürichsee. Ergebnisse der Ausgrabungen Mozartstrasse, Kanalisationssanierungen Seefeld, AKAD/Pressehaus und Mythenschloss in Zürich. Monographien der Kantonsarchäologie Zürich 20, Zürich and Egg: Fotorotar.

Schibler J and Jacomet S (2010) Short climatic fluctuations and their impact on human economies and societies: the potential of the Neolithic lake shore settlements in the Alpine foreland. Environmental Archaeology 15(2): 173182.

Schier W, Ehrmann O, Rösch M, et al. (2013) The economics of Neolithic swidden cultivation: results of an experimental long-term project in Forchtenberg 
(Baden-Württemberg, Germany). In: Kerig T and Zimmermann A (eds) Economic Archaeology: From Structure to Performance in European Archaeology. Bonn: Habelt Verlag, 97-108.

Schiffer MB (1991) Formation Processes of the Archaeological Record, Albuquerque (NM): University of New Mexico Press.

Schiffer MB (2002) Behavioural Archaeology, New York: Percheron Press.

Schlichtherle H (1981) Cruciferen als Nutzpflanzen in neolithischen Ufersiedlungen Südwestdeutschlands und der Schweiz. Zeitschrift für Archäologie 15: 113-124.

Schmidt E (2011) Insektenkundliche Flächenuntersuchungen in der endneolithischen Feuchtbodensiedlung Torwiesen II. Die endneolithische Moorsiedlung Bad Buchau-Torwiesen II am Federsee. Band 1: Naturwissenschaftliche Untersuchungen. Hemmenhofener Skripte 9, Freibung im Breisgau: Janus-Verlag, 281-337.

Smith BD (2001) Low-Level Food Production. Journal of Archaeological Research 9(1): 1-43.

Smith BD (2009) Resource Resilience, Human Niche Construction, and the LongTerm Sustainability of Pre-Columbian Subsistence Economies in the Mississippi River Valley Corridor. Journal of Ethnobiology 29(2): 167-183.

Smith BD (2011a) General patterns of niche construction and the management of 'wild' plant and animal resources by small-scale pre-industrial societies. Philosophical Transactions of the Royal Society B-Biological Sciences 366(1566): 836-848.

Smith BD (2011b) The subsistence economies of indigenous North American societies. A Handbook. Washington: Smithsonian Institution Scholarly Press, 616.

Steiner BL, Antolin F and Jacomet S (2015) Testing of the consistency of the sieving (wash-over) process of waterlogged sediments by multiple operators. Journal of Archaeological Science: Reports 2: 310-320.

Styring A, Maier U, Stephan E, et al. (2015 [in press]) Cultivation of choice: new insights into farming practices at Neolithic lakeshore sites. Antiquity doi:10.15184/aqy.2015.192.

Sugita S (2007a) Theory of quantitative reconstruction of vegetation I: pollen from large sites REVEALS regional vegetation composition. Chemosphere 17(2): 229-241.

Sugita S (2007b) Theory of quantitative reconstruction of vegetation II: all you need is LOVE. Holocene 17(2): 243-257. 
Suter PJ. (2008) Das endneolithische Becher-Phänomen - alternative Vorstellungen. In: Dörfler W and Müller J (eds) Umwelt, Wirtschaft, Siedlungen im dritten vorchristlichen Jahrtausend Mitteleuropas und Südskandinaviens. Internationale Tagung in Kiel, 4.-6. November 2005. OffaBücher 84, Neumünster: Wachholtz Verlag, 335-354.

Suter PJ and Francuz J (2010) Dendrochronologie: Datierung - Dorfgeschichte Waldnutzung der Ufersiedlung Sutz-Lattrigen-Rütte am Bielersee. In: Matuschik I, Strahm C, Eberschweiler B, et al. (eds) Vernetzungen. Aspekte siedlungsarchäologischer Forschung. Festschrift für Helmut Schlichtherle zum 60. Geburtstag. Freiburg i. Br.: Lavori Verlag, 179-205.

Tolar T, Jacomet S, Veluscek A, et al. (2009) Recovery techniques of waterlogged archaeological sediments - a comparison of different treatment methods of samples from Neolithic Lake shore settlements. Vegetation History and Archaeobotany 19(1): 53-68.

Tolar T, Jacomet S, Velušček A, et al. (2011) Plant economy at a late Neolithic lake dwelling site in Slovenia at the time of the Alpine Iceman. Vegetation History and Archaeobotany 20(3): 207-222.

Trondman AK, Gaillard MJ, Mazier F, et al. (2014) Pollen-based quantitative reconstructions of Holocene regional vegetation cover (plant-functional types and land-cover types) in Europe suitable for climate modelling. Global Change Biology: n/a-n/a.

Van der Veen M. (2007) Formation processes of desiccated and carbonized plant remains - the identification of routine practice. Journal of Archaeological Science 34: 968-990.

van Zeist WA and Boekschoten-van Helsdingen AM. (1991) Samen und Früchte aus Niederwil. In: Waterbolk HT and van Zeist WA (eds) Niederwil. Eine Siedlung der Pfyner Kultur. Band III: Naturwissenschaftliche Untersuchungen. Bern / Stuttgart: Verlag Paul Haupt, 49-113.

Vandorpe P and Jacomet S (2007) Comparing different pre-treatment methods for strongly compacted organic sediments prior to wet-sieving: a case study on Roman waterlogged deposits. Environmental Archaeology 12(2): 207-214.

Whittle A (1996) Europe in the Neolithic. The Creation of New Worlds. Cambridge University Press: Cambridge.

Willerding U (1986) Zur Geschichte der Unkräuter Europas, Göttingen: Karl Wachholtz Verlag. 
Willerding U (1999) Heu. In: Beck H, Geuenich D and Steuer H (eds) Reallexikon der Germanischen Altertumskunde. Berlin und New York: Walter de Gruyter, 510-526.

Zohary D, Hopf M and Weiss E (2012) Domestication of plants in the Old World: the origin and spread of domesticated plants in south-west Asia, Europe, and the Mediterranean Basin, Oxford: Oxford University Press. 


\section{List of illustrations and legends} Figures and Tables in the OSM = Online Supplementary Materials

\section{OSM figures}

Figure OSM 1. Chronological table with the cultural groups mentioned in the text. Abbreviations. MK=Michelsberger Kultur; LBK=Linearbandkeramik; SOB = Südostbayerisches Mittelneolithikum; $\mathrm{Br}-\mathrm{O}=\mathrm{Brubach}$ Oberbergen (from Jacomet, 2007b). In the region considered here there are Early and Middle Neolithic cultural groups, and the transition Mesolithic-Neolithic can be roughly placed into the sixth millennium cal BC.

Figure OSM 2. Development of herd sizes in the course of the Late Neolithic, based on densities (concentrations) of hand-collected animal bones (numbers per layer volume and settlement duration). After Schibler, 1997.

Figure OSM 3. The changing importance of cultivated plants during the Late Neolithic, based on roughly quantified data, showing their approximate importance. Only settlements with some kind of representative sampling and more than around 500 cereal remains are shown. Numbers in bold indicate years cal BC. Figure by S. Jacomet, published in Suter, 2008, p. 345.

Figure OSM 4. House plans and surface sampling of the settlement Zürich Parkhaus Opéra layer 13 (Horgen culture, 3175-3157 cal BC). For more details of features see Bleicher and Ruckstuhl, 2015 [in press]. Figure after Antolin et al., 2015 [in press].

Figure OSM 5. Ubiquity of some grassland taxa and changes in the course of the Late Neolithic (based on waterlogged seeds). Figure S. Jacomet.

Figure OSM 6. Heavily utilised woodland (mainly for coppicing); Nemrut Dagi, Southern Turkey (photograph S. Jacomet, June 2009). 
Figure OSM 7. Example of the ubiquitous presence of gathered plants in Late Neolithic lakeshore layers: densities (remains per litre of sediment, displacement volume) of subfossil hazelnut shells in Zurich Parkhaus Opéra layer 13 (Horgen culture, 3175-3157 cal BC). Figure by F. Antolin.

\section{OSM Tables}

OSM Table 1. List of wetland sites investigated by archaeobotany. For their location (numbers) see Figure 3 in the print text.

OSM Table 2. Bibliographic references to OSM Table 1.

OSM Table 3. List of wetland sites investigated by archaeozoology (large, handcollected bones). For their location (numbers) see Figure 4 in the print-text.

OSM Table 4: Bibliographic references to OSM Table 3.

OSM Table 5. List of weedy taxa found in Neolithic stocks of cereals and flax, and wild plants growing on experimental fields (more explanations in the text). Archaeobotanical data are based on Maier, 2001; Brombacher and Jacomet 1997; Brombacher and Jacomet 2003; Kreuz 2012. Experimental data from Rösch et al. 2002. 


\section{Page 109 of 141}

HOLOCENE

Chrono Tab_neu_2004.xls

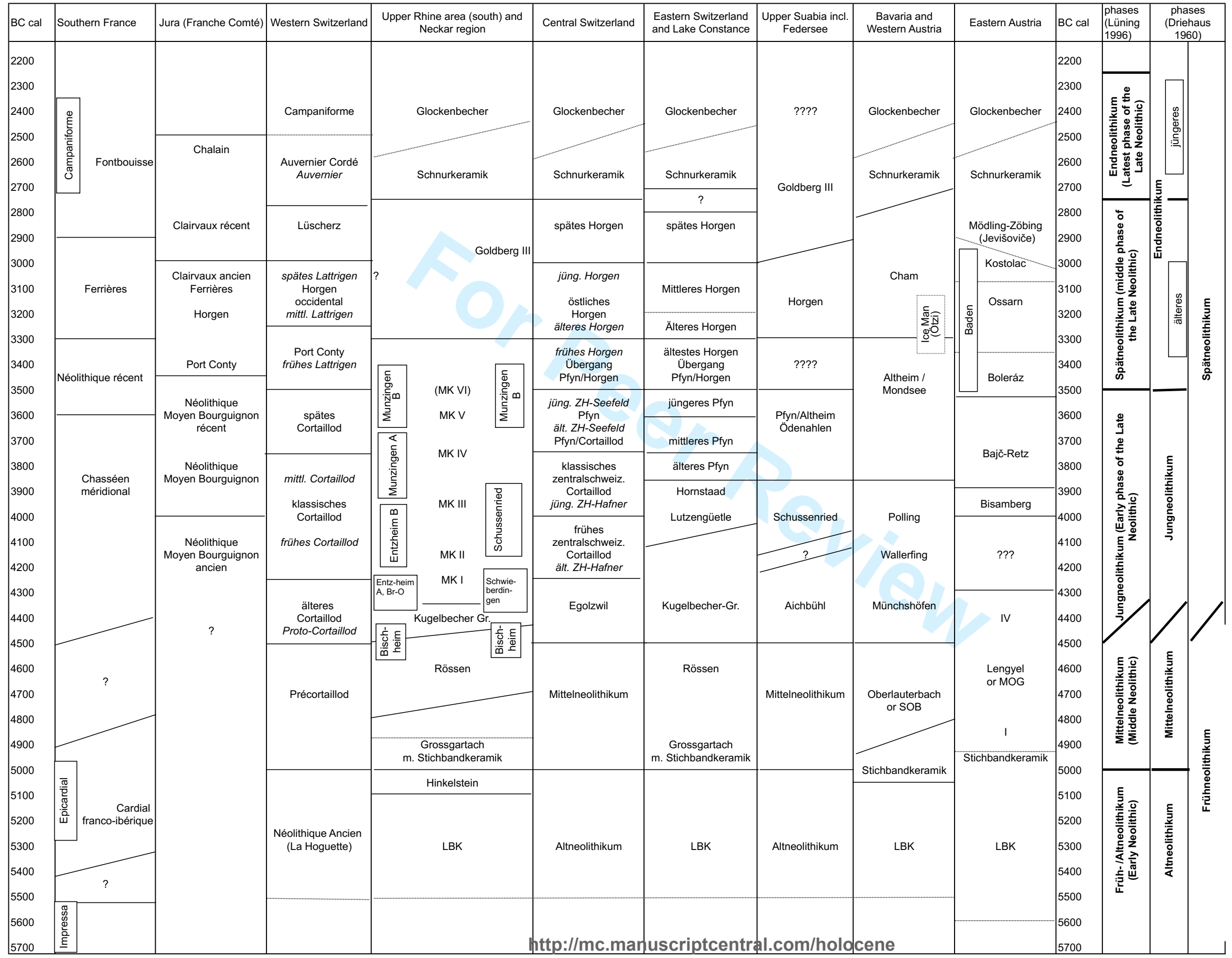




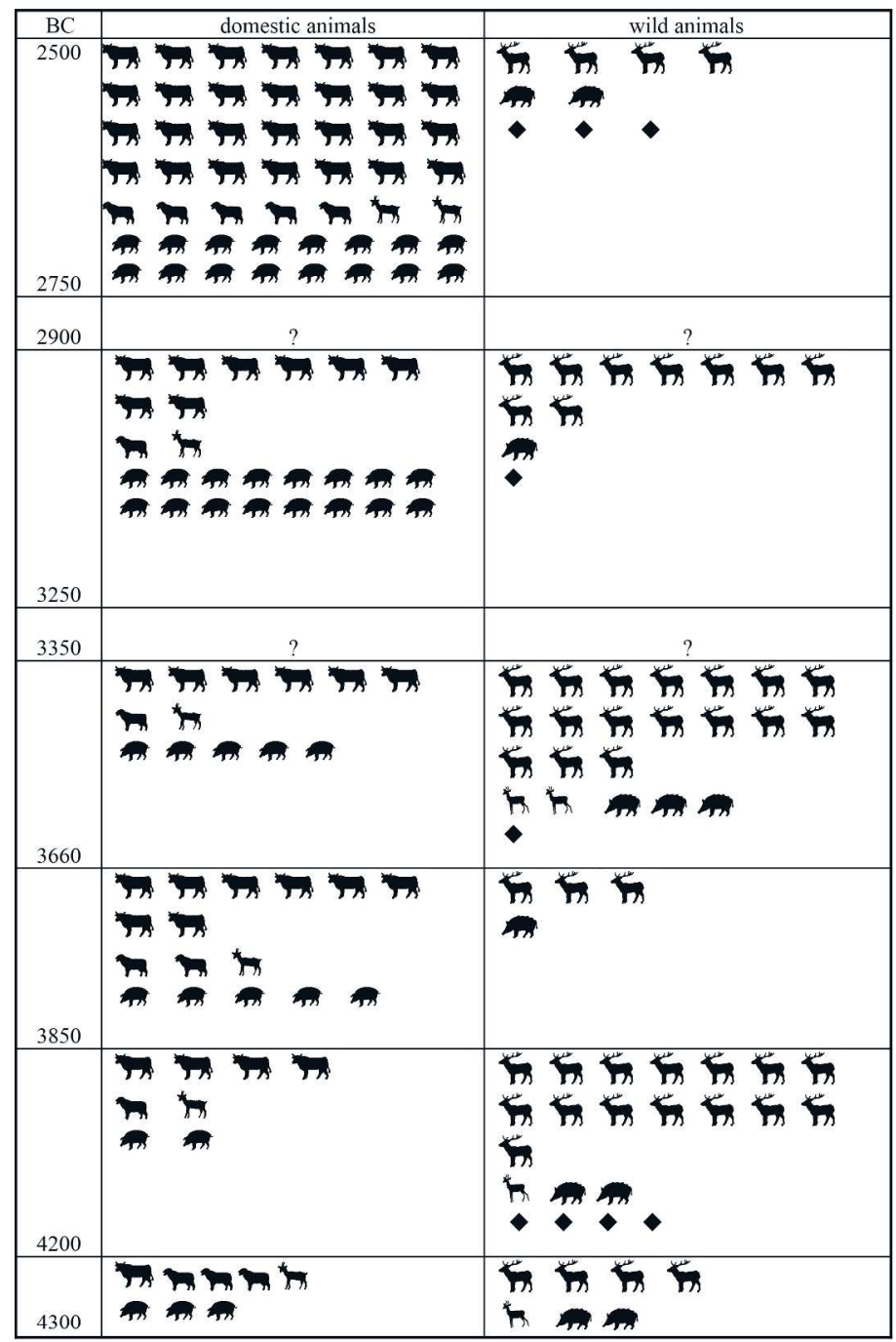

$201 \times 288 \mathrm{~mm}(300 \times 300$ DPI $)$ 
Fig. 10, Jacomet et al.

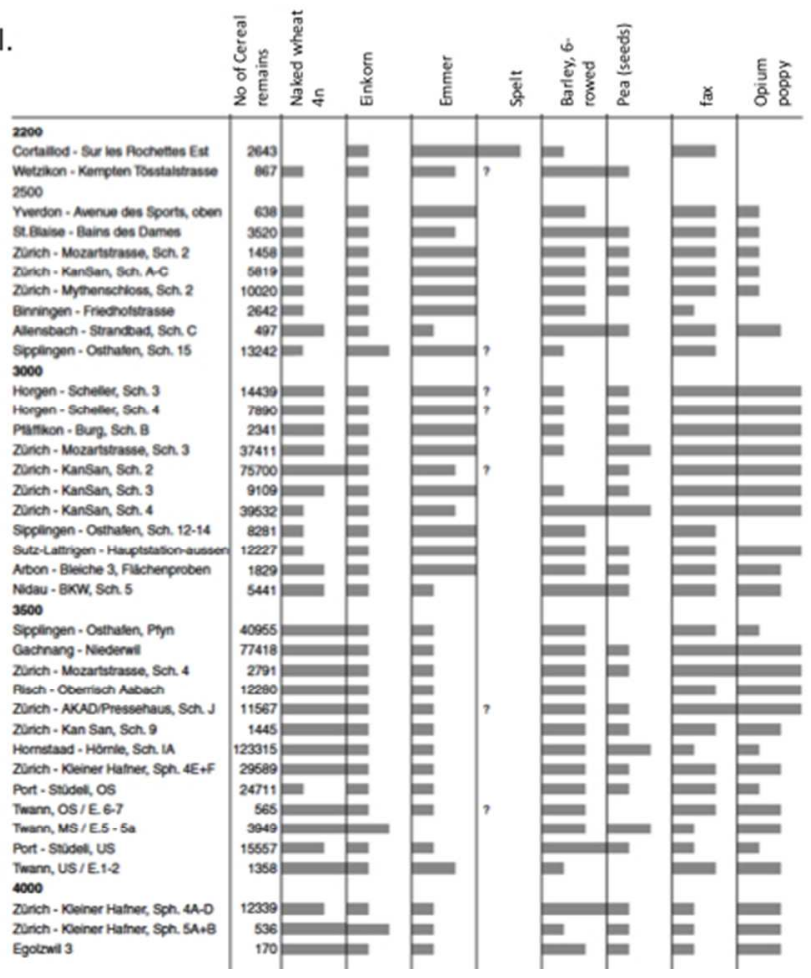

$254 \times 190 \mathrm{~mm}(72 \times 72$ DPI $)$ 


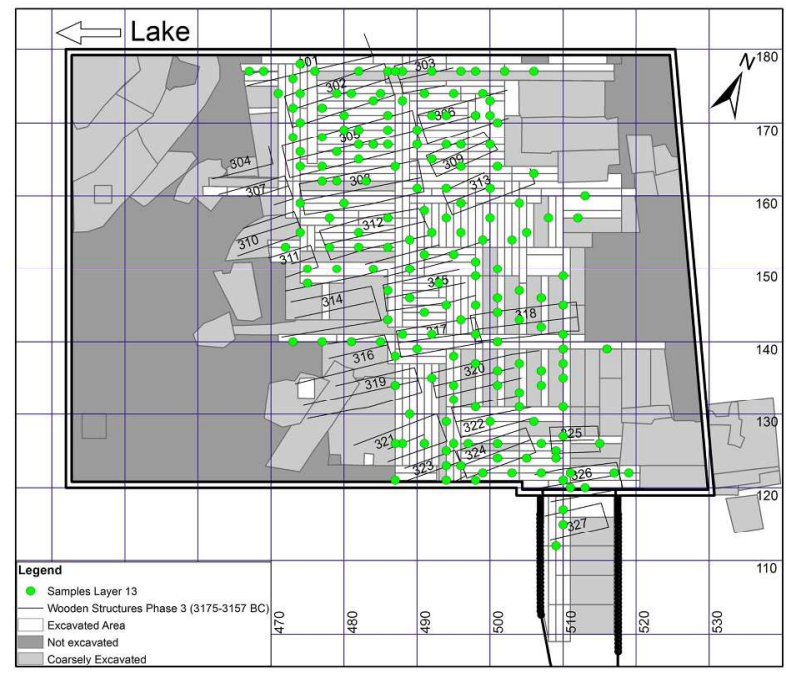

209x148mm (300 x 300 DPI) 
Fig. 12, Jacomet et al.

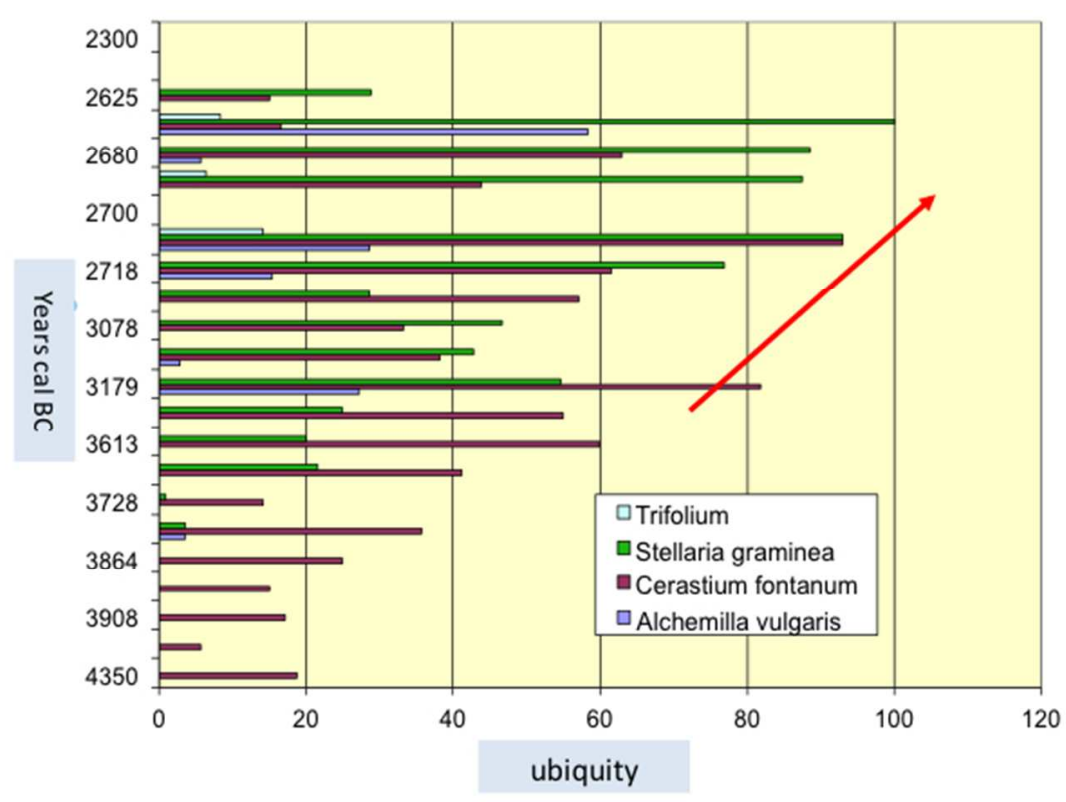

$254 \times 190 \mathrm{~mm}(72 \times 72 \mathrm{DPI})$ 


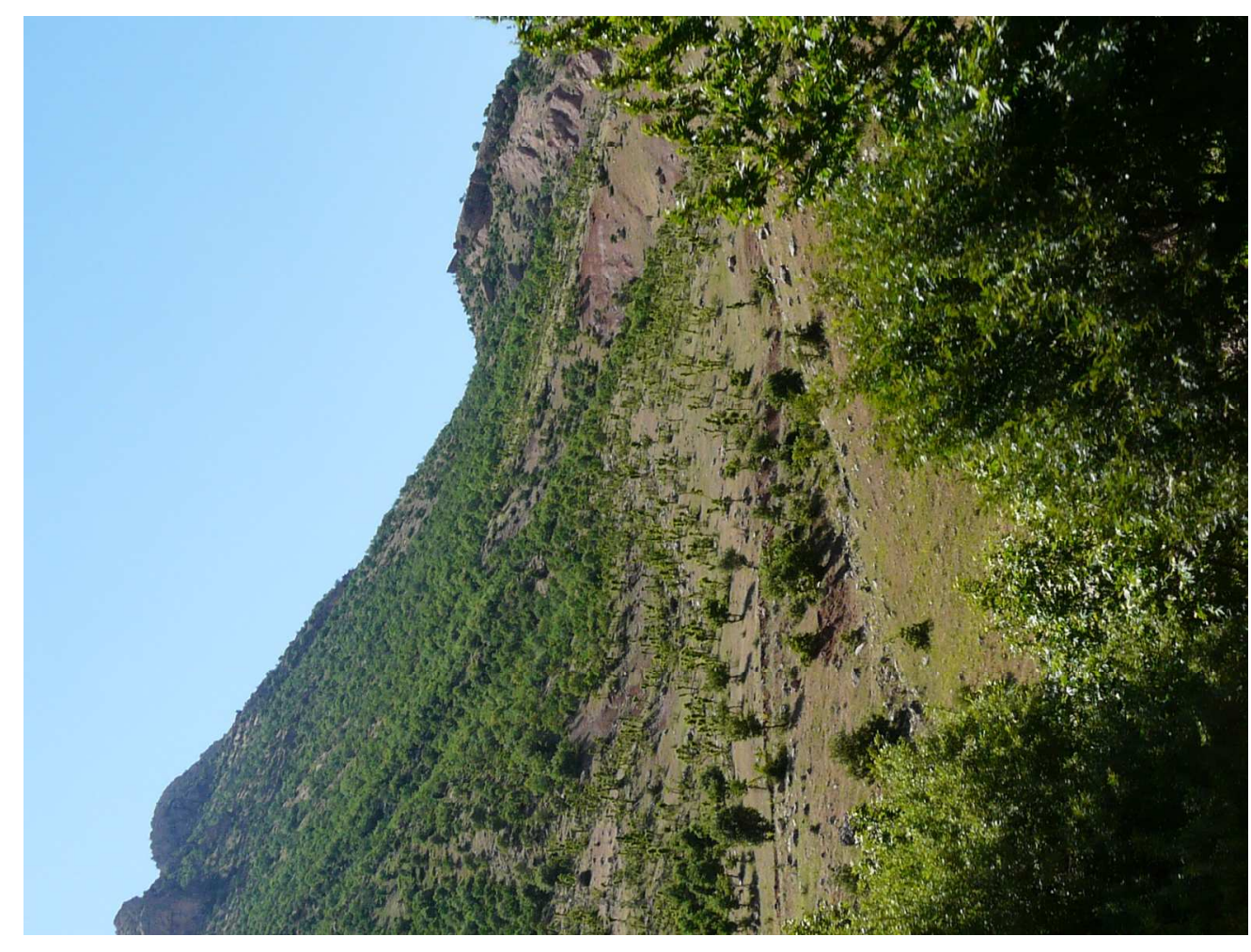

$722 \times 541 \mathrm{~mm}(72 \times 72$ DPI $)$ 


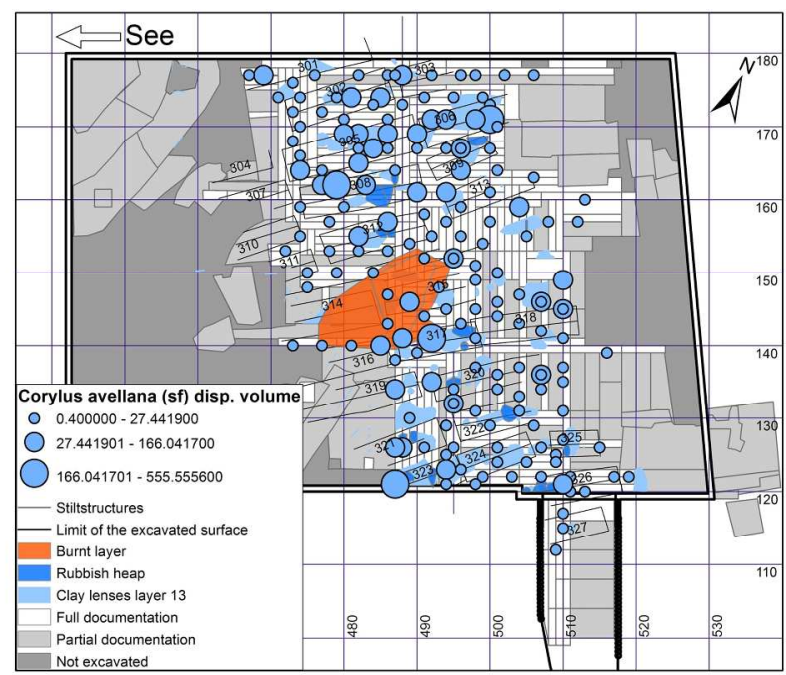

$209 \times 148 \mathrm{~mm}(300 \times 300$ DPI $)$ 


\begin{tabular}{|c|c|c|c|c|}
\hline $\begin{array}{ll}4 & \text { site / settlement (after numbers on map Fig. 3; within one site / } \\
5 & \text { region: after dating). Swiss sites not specified with country-code }\end{array}$ & 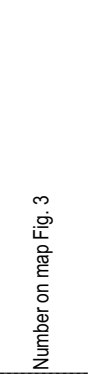 & 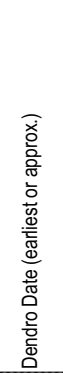 & culture (see Fig. OSM 1) & Publication of archaeobotanical data \\
\hline 10 $\frac{\text { Chalain (F) station 19, Schichten H-K }}{\text { Chalain (F) station 3, Schicht VIII }}$ & 1 & $\begin{array}{l}3050 \\
3198\end{array}$ & \begin{tabular}{|l|} 
Clairvaux Ancien \\
Horgen
\end{tabular} & \begin{tabular}{|l|l|} 
Schaal 2000 \\
Baudais et al 1997
\end{tabular} \\
\hline 11 Chalain (F) station 3, Schicht VIII & $\frac{1}{1}$ & $\begin{array}{l}3198 \\
3470\end{array}$ & \begin{tabular}{|l|l} 
Horgen \\
Port Conty
\end{tabular} & $\begin{array}{l}\text { Baudais et al. } 1997 \\
\text { Lundstrom-Baudais 1989a, b }\end{array}$ \\
\hline 12 Clairvaux (F) III, Schichten II und III (u und m) & 1 & 2975 & Clairvaux récent & Lundström-Baudais 1986 \\
\hline 12 Clairvaux (F) V Motte Aux Magnins & 1 & 3659 & Néolithique Moyen Bourguignon récent & Lundstrom-Baudais 1989c \\
\hline $13 \begin{array}{l}\text { Yverdon VD Avenue des Sports m (13/14-10, Schlichtherle-Profil) } \\
\text { Yverdon VD Avenue des Sports o (9a-2 Schlichtherle Profil) }\end{array}$ & $\frac{2}{2}$ & $\frac{2730}{22600}$ & \begin{tabular}{|l} 
Auvernier Cordé, früh \\
Auvernier Cordé
\end{tabular} & \begin{tabular}{|l|} 
Schlichtherle 1985; Wolf 1993 \\
Schlichtherle 1985: Wolf 1993
\end{tabular} \\
\hline 14 Yverdon VD Avenue des Sports u (Schi 16-14, Schlichtherle-Profil) & 2 & 2750 & Lüscherz récent & Schlichtherle 1985; Wolf 1993 \\
\hline 15 Concise VD Sous Colachoz AUC (Häuff.Klass.) & 3 & 2699 & Auvernier Cordé & Karg \& Märkle 2002 \\
\hline 18 Concise VD Sous Colachoz COT2 (Häuf.-Klass.) & 3 & 3567 & Cortaillod tardif & Karg \& Märkle 2002 \\
\hline Auvernier NE Brise-Lames & 4 & 2792 & Lüscherz & Baudais-Lundström 1978 \\
\hline 19 St.Blaise NE Bains des Dames (Auv. Cordé Anc.) & 6 & 2700 & Auvernier Cordé Ancien & Mermod 2007 \\
\hline 20 St.Blaise NE Bains des Dames (Auv. Cordé Moy.) & 6 & 2600 & Auvernier Cordé Moyen & Mermod 2007 \\
\hline St.Blaise NE Bains des Dames (Lüscherz) & 6 & 2900 & Lüscherz récent & Mermod 2007 \\
\hline 21 Twann BE mittl. Horgener KS & 7 & 3176 & Horgen occidental (Lattrigen, spätes) & Piening 1981 \\
\hline $22^{T}$ Twann BE MS (E3-4) & 7 & 3702 & Cortaillod tardif & Ammann et al. 1981 \\
\hline 22 Twann BE MS (E5 - 5a) & 7 & 3643 & Cortaillod tardif & Ammann et al. 1981 \\
\hline 23 Twann BE OS (6-7) & 7 & 3596 & Cortaillod tardif & Ammann et al. 1981 \\
\hline Twann BE OS (E8-9) & 7 & 3536 & Cortaillod tardif & Ammann et al. 1981 \\
\hline 24 Twann BE US, E1-2 & 7 & 3838 & Cortaillod classique & Ammann et al. 1981 \\
\hline 25 Lüscherz BE Kleine Station XV, Schn. 1-3 & 8 & 3410 & Horgen occidental (Lattrigen, frühes) & Brombacher 1997 \\
\hline 25 Sutz BE Lattrigen VI, Riedstation & 9 & 3410 & Horgen occidental (Lattrigen, frühes) & Brombacher 1997 \\
\hline 26 Sutz BE Lattrigen, Hauptstation VII, aussen & 9 & 3203 & Horgen occidental (Lattrigen, spätes) & Brombacher 1997 \\
\hline Port BE Stüdeli, OS & 10 & 3572 & Cortaillod, spätes & Brombacher \& Jacomet 2003 \\
\hline 27 Port BE Stüdeli, US & 10 & 3686 & Cortaillod, spätes & Brombacher \& Jacomet 2003 \\
\hline 28 Nidau BE Schlossmatte BKW Ib, Schicht 5 & 11 & 3406 & Horgen occidental (Lattrigen, frühes) & Brombacher 1997, 2000, sowie Hafner und Suter 2000 \\
\hline Seeberg BE Burgäschisee-Süd & 12 & 3760 & Cortaillod, klass. Zentralschweizerisches bzw. Zürich Hafner & Villaret-von Rochow 1967 \\
\hline 29 Egolzwil LU 3, Wuuwiler Moos & 13 & 4282 & Egolzwiler K. & Bollinger 1994a und $b$ \\
\hline 30 Risch ZG Oberrisch, Aabach, & 14 & 3710 & Pfyner K. bzw. Zürich-Seefeld & Jacomet, unpublished data \\
\hline Cham ZG Eslen & 15 & 4225 & Egolzwilffrühes zs. Cortaillod bzw. Zürich Hafner & Martinoli \& Jacomet 2002; Brombacher, in prep. \\
\hline Zug ZG Riedmatt & near 16 & 3100 & Horgener $\mathrm{K}$. & Jacomet \& Antolin 2010 (unpublished report) \\
\hline $3 \angle$ Oberrieden ZH Riet & near 18 & 3300 & Horgener $\mathrm{K}_{\text {., früh }}$ & Jacomet 2004 \\
\hline 33 Zug ZG Vorstadt 26, Rössliwiese & 17 & 3050 & Horgener $\mathrm{K}$. & Jacomet \& Wagner 1987 \\
\hline Horgen ZH Dampfschiffsteg & 18 & 3713 & Pfyner K. & Pawlik \& Schweingruber 1976 \\
\hline 34 Horgen ZH Scheller 3 & 18 & 3061 & Horgener $\mathrm{K}$. & Favre 2001, 2002 \\
\hline 35 Horgen ZH Scheller 4 & 18 & 3078 & Horgener $\mathrm{K}$. & Favre 2001, 2002 \\
\hline Zürich Mozartstrasse Schicht 2 & 19 & 2625 & Schnurkeramik & Jacomet, Brombacher, Dick 1989 \\
\hline 36 Zürich KanSan Schicht A & 19 & 2675 & Schnurkeramik & Brombacher \& Jacomet 1997 \\
\hline 37 Zürich Mythenschloss Schicht 2 & 19 & 2680 & Schnurkeramik & Jacomet, Brombacher, Dick 1989 \\
\hline Zürich KanSan Schicht B/C & 19 & 2685 & Schnurkeramik & Brombacher \& Jacomet 1997 \\
\hline 38 Zürich KanSan Schicht D & 19 & 2705 & Schnurkeramik & Brombacher \& Jacomet 1997 \\
\hline Zürich KanSan Kreuzstr. B,D (nur Getreide) & 19 & 2718 & Schnurkeramik & Brombacher \& Jacomet 1997 \\
\hline 39 Zürich KanSan SchichtE E (F?) & 19 & 2718 & Schnurkeramik & Brombacher \& Jacomet 1997 \\
\hline 40 Zürich AKAD/Pressehaus, Schicht C2 & 19 & 2719 & Schnurkeramik & Jacomet-Engel 1980; Brombacher \& Jacomet 1997 \\
\hline Zürich KanSan Schicht 2A & 19 & 2911 & Horgener K. & Brombacher \& Jacomet 1997 \\
\hline 41 Zürich PParkhaus Opéra Schicht 14 & 19 & 3090 & Horgener $\mathrm{K}$. & Antolin et al. 2015; Antolin et al. 2016 \\
\hline 42 Zürich KanSSan Schicht 2 & 19 & 3126 & Horgener $\mathrm{K}$. & Brombacher \& Jacomet 1997 \\
\hline 42 Zürich Mozartstrasse Schicht 3 & 19 & 3126 & Horgener $\mathrm{K}$. & Jacomet, Brombacher, Dick 1989 \\
\hline 43 Zürich Parkhaus Opéra Schicht 13 & 19 & 3165 & Horgener $\mathrm{K}$. & Antolin et al. 2015; Antolin et al. 2016 \\
\hline Zürich KanSan Schicht 3 & 19 & 3179 & Horgener K. & Brombacher \& Jacomet 1997 \\
\hline
\end{tabular}




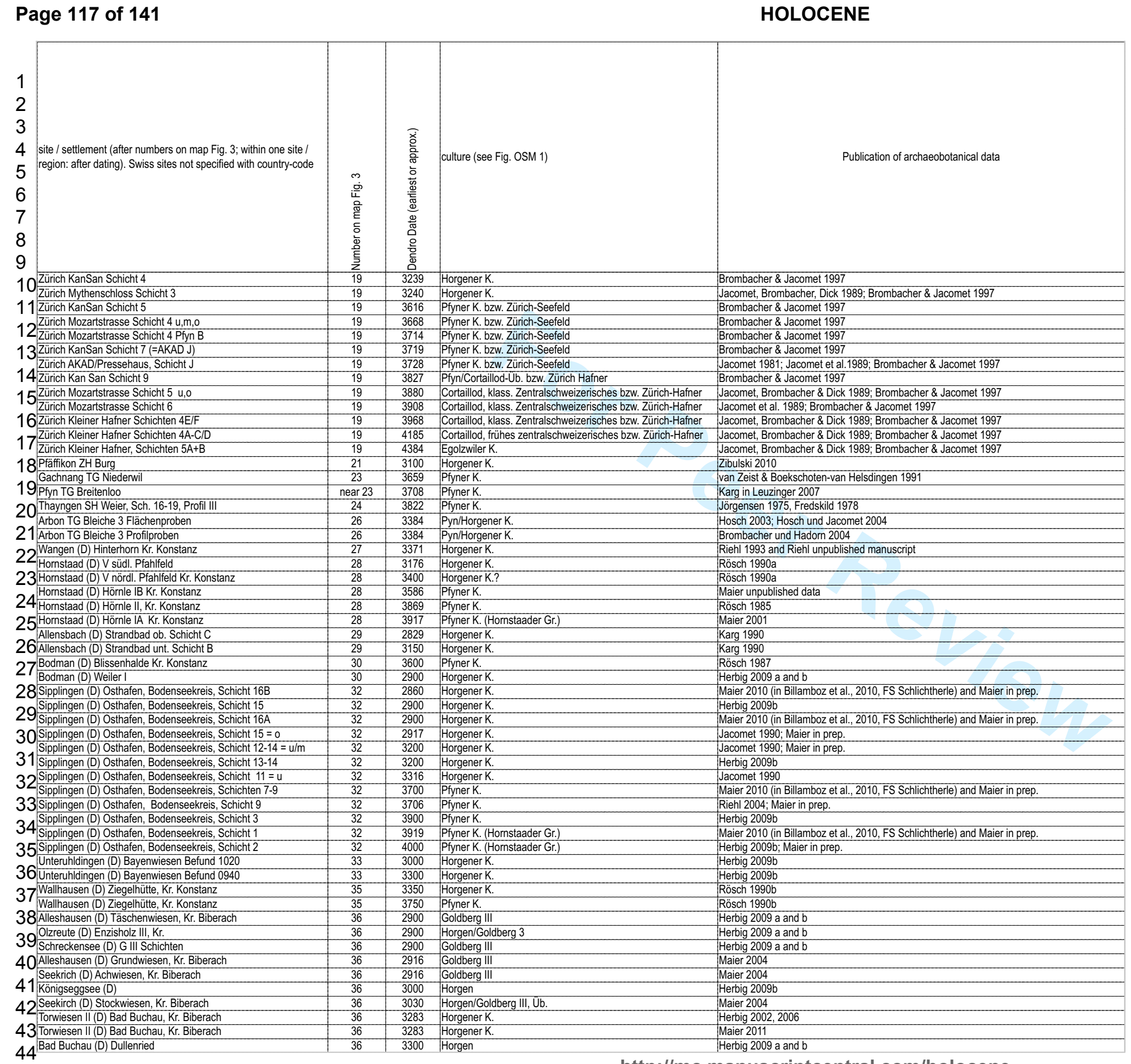

http://mc.manuscriptcentral.com/holocene 
HOLOCENE

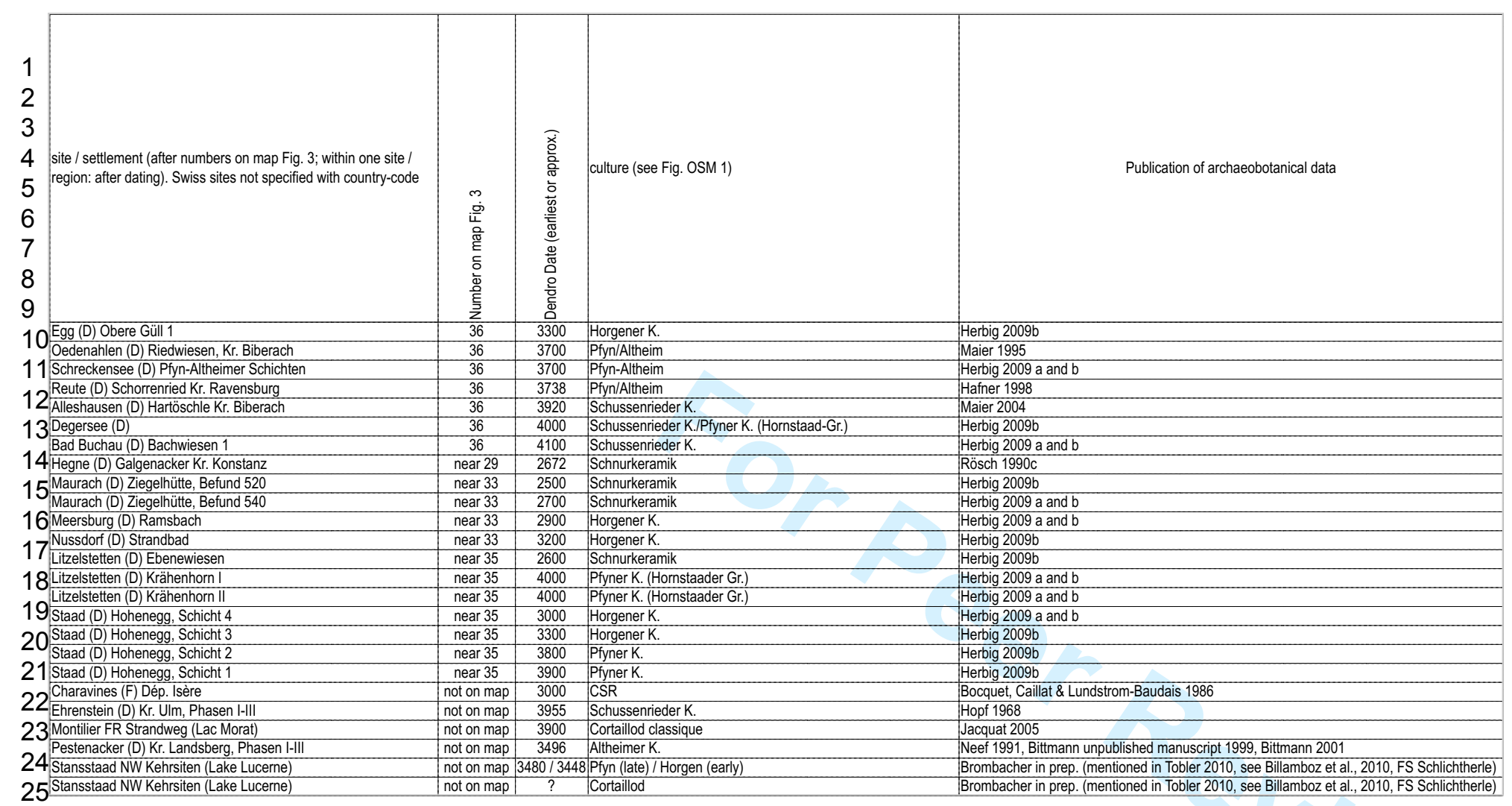


Table OSM 2

\section{References to Table OSM 1 (and Figure 3)}

Ammann B, Bollinger T, Jacomet S, et al. (1981) Die neolithischen Ufersiedlungen von Twann 14: Botanische Untersuchungen, Bern: Staatlicher Lehrmittelverlag.

Antolin F, Bleicher N, Brombacher C, et al. (2015) Quantitative approximation to largeseeded wild fruit use in a late Neolithic lake dwelling. The case study of layer 13 of Parkhaus Opéra in Zürich (Central Switzerland). Quaternary International. http://dx.doi.org/10.1016/j.quaint.2015.08.003

Baudais D, Grudler A and Lundström-Baudais K. (1997) Les paléosemeces du niveau VIII et leur répartition spatiale. In: Pétrequin P (ed) Les sites littoraux néolithiques des Clairvaux-les-Lacs et de Chalain (Jura) III: Chalain Station 3, 3200-2900 av. J.-C., Vol. 2. Paris: Editions de la Maison des Sciences de l'Homme, 723-732.

Baudais-Lundström K. (1978) Plant remains from a swiss neolithic lakeshore site: BriseLames, Auvernier. Berichte der Deutschen Botanischen Gesellschaft 91: 67-83.

Billamboz A, Maier U, Matuschik I, et al. (2010) Die jung- und endneolithischen Seeufersiedlungen von Sipplingen "Osthafen" am Bodensee: Besiedlungs- und Wirtschaftsdynamik im eng begrenzten Naturraum des Sipplinger Dreiecks. In: Matuschik I and Strahm C (eds) Vernetzungen. Aspekte siedlungsarchäologischer Forschung. Festschrift für Helmut Schlichtherle zum 60. Geburtstag. Freiburg i. Br.: Lavori Verlag, 253-286.

Bittmann F. (2001) Die jungneolithische Feuchtbodensiedlung Pestenacker, Lkr. Landsberg/Lech - Auswirkungen auf die Landschaft aus botanischer Sicht. DFG Graduiertenkolleg 462. "Paläoökosystemforschung und Geschichte". Beiträge zur Siedlungsarchäologie und zum Lanschaftswandel. Ergebnisse zweier Kolloquien in Regensburg 9. - 10. Oktober 2000, 2. - 3. November 2000. Regensburg: Universitätsverlag, 93-107.

Bocquet A, Caillat R and Lundstroem-Baudais K. (1986) Alimentation et techniques de cuisson dans le village néolithique de Charavines - Isère. In: Demoule JP and Guilaine J (eds) Le Néolithique de la France. Hommage à Gérard Bailloud. Paris: Picard, 319-329.

Bollinger T. (1994a) Samenanalytische Untersuchung der früh-jungsteinzeitlichen Seeufersiedlung Egolzwil 3, Stuttgart, Berlin.

Bollinger T. (1994b) Wirtschaft und Umwelt des jungsteinzeitlichen Wohnplatzes Egolzwil 3. Heimatkunde des Wiggertales 52: 137-224.

Brombacher C. (1997) Archaeobotanical investigations of Late Neolithic lakeshore settlements (Lake Biel, Switzerland). Vegetation History and Archaeobotany 6(3): 167-186.

Brombacher C. (2000) Archäobotanische Untersuchungen. In: Hafner A and Suter P (eds) -3400. Die Entwicklung der Bauerngesellschaften im 4. Jahrtausend v. Chr. am Bielersee aufgrund der Rettungsgrabungen von Nidau und Sutz-Lattrigen. Bern: Paul Haupt Verlag, 155-168.

Brombacher C and Hadorn P. (2004) Untersuchungen der Pollen und Makroresten aus den Profilsäulen. In: Jacomet S, Leuzinger U and Schibler J (eds) Die neolithische Seeufersiedlung Arbon Bleiche 3. Umwelt und Wirtschaft. Frauenfeld: Amt für Archäologie des Kantons Thurgau, 50-65.

Brombacher C and Jacomet S. (1997) Ackerbau, Sammelwirtschaft und Umwelt: Ergebnisse archäobotanischer Untersuchungen. In: Schibler J, Hüster-Plogmann H, Jacomet S, et al. (eds) Ökonomie und Ökologie neolithischer und bronzezeitlicher Ufersiedlungen am Zürichsee. Ergebnisse der Ausgrabungen Mozartstrasse, 
Kanalisationssanierungen Seefeld, AKAD/Pressehaus und Mythenschloss in Zürich. Zürich und Egg: Direktion der öffentlichen Bauten des Kantons Zürich, 220-279. Brombacher C and Jacomet S. (2003) Ackerbau, Sammelwirtschaft und Umwelt. In: Zwahlen H (ed) Die jungneolithische Siedlung Port-Stüdeli. Bern: Paul Haupt Verlag, 66-86.

Favre P. (2001) Analyse pflanzlicher Grossreste aus den spätneolithischen Ufersiedlungen von Horgen-Scheller, Kanton Zürich, Schweiz. Ein Beitrag zu Umwelt- und Wirtschaftsgeschichte des 31. Jh. v. Chr. im nördlichen Alpenvorland. PhD Thesis, University of Basel.

Favre P. (2002) Archäobotanik. In: Achour-Uster C, Eberli U, Ebersbach R, et al. (eds) Die Seeufersiedlungen in Horgen. Die neolithischen und bronzezeitlichen Fundstellen Dampfschiffsteg und Scheller. Zürich / Egg: Fotorotar, 150-180.

Fredskild B. (1978) Seeds and Fruits of the Neolithic Settlement Weier, Switzerland. Botanisk Tidsskrift 72: 189-201.

Hafner A. (1998) Archäobotanische Untersuchungen in Reute-Schorrenried. In: Mainberger M (ed) Das Moordorf von Reute. Archäologische Untersuchungen in der jungneolithischen Siedlung Reute Schoirrenried. Staufen i. Br.: Taraqua CAP, 385-418.

Hafner A and Suter P. (2000) -3400. Die Entwicklung der Bauerngesellschaften im 4. Jahrtausend v. Chr. am Bielersee. Bern: Paul Haupt Verlag.

Herbig C. (2002) Archäobotanische Untersuchungen in der spätneolithischen Moorsiedlung Torwiesen II im Federseemoor (Stadt Buchau, Kreis Biberach). Master Thesis, Seminar für Vor- und Frühgeschichte. Frankfurt am Main: Johann Wolfgang Goethe Universität.

Herbig C. (2006) Archaeobotanical investigations in a settlement of the Horgener culture (3300 BC) 'Torwiesen II' at Lake Federsee, southern Germany (Archaobotanische Untersuchungen in einer Siedlung der Horgener Kultur (3300 BC) 'Torwiesen II' am Federsee, Suddeutschland). Environmental Archaeology 11(1): 131-142.

Herbig C. (2009a) Archäobotanische Untersuchungen in neolithischen Feuchtbodensiedlungen am westlichen Bodensee und in Oberschwaben, Bonn: Verlag Dr. Rudolf Habelt.

Herbig C. (2009b) Recent archaeobotanical investigations into the range and abundance of Neolithic crop plants in settlements around Lake Constance and in Upper Swabia (south-west Germany) in relation to cultural influences. Journal of Archaeological Science 36: 1277-1285.

Hopf M. (1968) Früchte und Samen. In: Zürn H (ed) Das jungsteinzeitliche Dorf Ehrenstein (Kreis Ulm). Stuttgart, 7-77.

Hosch S. (2003) Ackerbau und Sammelwirtschaft in der neolithischen Seeufersiedlung Arbon Bleiche 3 (3384-3370 v.Chr.) Kanton Thurgau, Schweiz. PhD Thesis, Institute for Prehistory and Archaeological Science. Basel University.

Hosch S and Jacomet S. (2004) Ackerbau und Sammelwirtschaft. Ergebnisse der Untersuchung von Samen und Früchten. In: Jacomet S, Schibler J and Leuzinger U (eds) Die neolithische Seeufersiedlung Arbon Bleiche 3: Wirtschaft und Umwelt. Frauenfeld: Amt für Archäologie des Kantons Thurgau, 112-157.

Jacomet-Engel S. (1980) Botanische Makroreste aus den neolithischen Seeufersiedlungen des Areals Pressehaus Ringier in Zürich (Schweiz). Stratigraphische und vegetationskundliche Auswertung. Vierteljahrsschrift der Naturforschenden Gesellschaft Zürich 125: 73-175. 
Jacomet S. (1981) Neue Untersuchungen botanischer Grossreste an jungsteinzeitlichen Seeufersiedlungen im Gebiet der Stadt Zürich (Schweiz). Zeitschrift für Archäologie 15: 125-140.

Jacomet S. (1986) Kulturpflanzenfunde aus der neolithischen Seeufersiedlung Cham St.Andreas. Jahrbuch der Schweizerischen Gesellschaft für Ur- und Frühgeschichte 69: 55-62.

Jacomet S. (1987) Ackerbau, Sammelwirtschaft und Umwelt der Egolzwiler- und Cortaillod-Siedlungen auf dem Kleinen Hafner in Zürich. In: Suter P (ed) Zürich "Kleiner Hafner". Tauchgrabung 1981-1984. Zürich: Oell Füssli, 144-166.

Jacomet S. (1990) Veränderungen von Wirtschaft und Umwelt während des Spätneolithikums im westlichen Bodenseegebiet. Ergebnisse samenanalytischer Untersuchungen an einem Profilblock aus der Horgener Schichtabfolge von Sipplingen-Osthafen (Tauchsondierung Ruoff 1980). Siedlungsarchäologie im Alpenvorland II. Berichte zu den Ufer- und Moorsiedlungen Südwestdeutschlands. Stuttgart: Konrad Theiss Verlag, 295-324.

Jacomet S. (2004) Archäobotanische Grobuntersuchung verkohlter Getreideklumpen. in: Hügi, Ursula; Michel-Tobler, Christine: Oberrieden ZH-Riet - eine frühhorgenzeitliche Siedlung. Jahrbuch der Schweizerischen Gesellschaft für Urund Frühgeschichte 87: 21-23.

Jacomet S, Brombacher C and Dick M. (1989) Archäobotanik am Zürichsee. Ackerbau, Sammelwirtschaft und Umwelt von neolithischen und bronzezeitlichen Seeufersiedlungen im Raum Zürich. Ergebnisse von Untersuchungen pflanzlicher Makroreste der Jahre 1979-1988, Zürich: Orell Füssli Verlag.

Jacomet S, Leuzinger U and Schibler J. (2004) Die neolithische Seeufersiedlung Arbon Bleiche 3. Umwelt und Wirtschaft, Frauenfeld: Amt für Archäologie des Kantons Thurgau.

Jacomet S and Wagner C. (1987) Verkohlte Pflanzenreste aus der Horgener Kulturschicht von Zug-Vorstadt 26. Jahrbuch der Schweizerischen Gesellschaft für Ur- und Frühgeschichte 70: 175-180.

Jacomet-Engel S. (1980) Botanische Makroreste aus den neolithischen Seeufersiedlungen des Areals Pressehaus Ringier in Zürich (Schweiz). Stratigraphische und vegetationskundliche Auswertung. Vierteljahrsschrift der Naturforschenden Gesellschaft Zürich 125: 73-175.

Jacquat C. (2005) Analyse carpologique des sédiments. In: Mauvilly M and Boisaubert J-L (eds) Montilier/Dorf, fouille Strandweg 1992/1993, nouvelles données sur la Culture Cortaillod au bord du lac de Morat. Cahiers d'Archéologie Fribourgeoise 8:18-22.

Jörgensen G. (1975) Triticum aestivum s.l. from the Neolithic Site of Weier in Switzerland. Folia Quaternaria 46: 7-21.

Karg S. (1990) Pflanzliche Grossreste der jungsteinzeitlichen Ufersiedlungen von Allensbach-Strandbad. Wildpflanzen und Anbaufrüchte als stratigraphische, ökologische und wirtschaftliche Informationsquellen. In: Siedlungsarchäologie im Alpenvorland II. Berichte zu den Ufer- und Moorsiedlungen Südwestdeutschlands. Stuttgart: Konrad Theiss Verlag, 113-166.

Karg S and Märkle T. (2002) Continuity and changes in plant resources during the Neolithic period in western Switzerland. Vegetation History and Archaeobotany 11(1-2): 169-176.

Leuzinger U. (2007) Pfyn-Breitenloo - Die jungsteinzeitliche Pfahlbausiedlung. Archäologie im Thurgau 14. Frauenfeld: Amt für Archäologie des Kantons Thurgau. 
Lundström-Baudais K. (1986) Étude paléoethnobotanique de la station III de Clairvaux. In: Pétrequin P (ed) Les Sites Littoraux Néolithiques de Clairvaux-Les-Lacs (Jura) I. Problématique générale. L'exemple de la Station. Paris, 311-404.

Lundström-Baudais K. (1989a) Etude des paléosemences de la station. In: Pétrequin P (ed) Le Néolithique moyen. Paris: Éditions de la Maison des sciences de l'homme, 193-194.

Lundström-Baudais K. (1989b) L'intégration de la station VIII dans l'ensemble des études de paléosemences des sites de Clairvaux. In: Pétrequin P (ed) $L e$ Néolithique moyen. Paris: Éditions de la Maison des sciences de l'homme, 491492.

Lundström-Baudais K. (1989c) Les macrorestes végétaux du niveau V de la Motte-auxMagnins. In: Pétrequin P (ed) Les sites littoraux néolithiques de Clairvaux-les-Lacs (Jura) II: Le Néolithique moyen. Paris: Éditions de la Maison des Sciences de l'Homme, 417-439.

Maier U. (1995) Moorstratigraphische und paläobotanische Untersuchungen in der jungsteinzeitlichen Moorsiedlung Ödenahlen am Federsee. In: Unz, C (ed) Siedlungsarchäologie im Alpenvorland III. Die neolithische Moorsiedlung Ödenahlen. Stuttgart: Konrad Theiss Verlag, 143-253.

Maier U. (2001) Archäobotanische Untersuchungen in der neolithischen Ufersiedlung Hornstaad-Hörnle IA am Bodensee. In: Maier U and Vogt R (eds) Siedlungsarchäologie im Alpenvorland VI. Botanische und pedologische Untersuchungen zur Ufersiedlung Hornstaad-Hörnle IA. Stuttgart: Konrad Theiss Verlag, 9-384.

Maier U. (2004) Archäobotanische Untersuchungen in jung- und endneolithischen Moorsiedlungen am Federsee (mit einem Beitrag von Richard Vogt). In: Köninger J and Schlichtherle H (eds) Ökonomischer und ökologischer Wandel am vorgeschichtlichen Federsee. Archäologische und naturwissenschaftliche Untersuchungen. Hemmenhofener Skripte 5. Gaienhofen-Hemmenhofen: Landesdenkmalamt Baden-Württemberg, 71-159.

Maier U and Harwath A. (2011) Detecting intra-site patterns with systematic sampling strategies. Archaeobotanical grid sampling of the lakeshore settlement Bad Buchau-Torwiesen II, southwest Germany. Vegetation History and Archaeobotany 20(5): 349-365.

Maier U and Herbig C. (2011) Archäobotanische Flächenuntersuchungen in der endneolithischen Feuchtbodensiedlung Torwiesen II. . Die endneolithische Moorsiedlung Bad Buchau-Torwiesen II am Federsee. Band 1:

Naturwissenschaftliche Untersuchungen. Hemmenhofener Skripte 9. Freibung im Breisgau: Janus-Verlag.

Märkle T. (2000) Die Wildpflanzen der Cortaillod moyen-zeitlichen Besiedlung von Concise-sous-Colachoz, Kt. Waadt, Schweiz. Eine Analyse der botanischen Makroreste. Master Thesis. Institut für Ur- und Frühgeschichte. University of Tübingen.

Martinoli D and Jacomet S. (2002) Pflanzenfunde aus Cham-Eslen: Erste Ergebnisse zur Versorgung mit pflanzlichen Nahrungsmitteln. Tugium 18: 76-77.

Mermod 0. (2007) Saint-Blaise/Bains des Dames 4. Archäobotanik einer Endneolithischen Seeufersiedlung: Vegetation, Ackerbau, Ernährung. Archéologie Neuchâteloise numérique 2. Hauterive.

Michel-Tobler C. (2010) Stansstad-Kehrsiten - Neolithische Seeufersiedlungen hart am Alpenrand. In: Matuschik I, Strahm C, Eberschweiler B, et al. (eds) Vernetzungen. 
Aspekte siedlungsarchäologischer Forschungen. Festschrift für Helmut

Schlichtherle zum 60. Geburtstag Freiburg im Breisgau: Lavori, 287-296.

Neef R. (1991) Botanische Untersuchungen im jungneolithischen Pestenacker. Die ersten Ergebnisse. Berichte der Römisch Germanischen Kommission 71: 381-389.

Pawlik B and Schweingruber FH. (1976) Die archäologisch-vegetationskundliche Bedeutung der Hölzer und Samen in den Sedimenten der Seeufersiedlung Horgen Dampfschiffsteg. Jahrbuch der Schweizerischen Gesellschaft für Ur- und Frühgeschichte 59: 77-91.

Piening U. (1981) Die verkohlten Kulturpflanzenreste aus den Proben der Cortaillodund Horgener Kultur. In: Ammann B, Bollinger T, Jacomet S, et al. (eds) Die neolithischen Ufersiedlungen von Twann 14: Botanische Untersuchungen. Bern: Staatlicher Lehrmittelverlag, 69-88.

Riehl S. (1993) Botanische Grossreste aus einer neolithischen Profilabfolge. Die Horgenzeitliche seeufersiedlung Wangen / Bodensee. Master Thesis, Institut für Ur- und Frühgeschichte. University of Tübingen.

Riehl S. (2004) Jungneolithische Pflanzenproduktion und Nutzung des Naturraums am Überlinger See / Bodensee. Archäobotanische Untersuchungen an Kulturschichtsedimenten aus der Sueefersiedlung Sipplingen. In: Billamboz A, Riehl S, Schmidt E, et al. (eds) Siedlungen der Pfyner Kultur im Osten der Pfahlbaubucht von Sipplingen, Bodenseekreis. Band 2: Naturwissenschaftliche Untersuchungen. Hemmenhofener Skripte 4. Freiburg i. Br.: Janus Verlag, 9-76.

Rösch M. (1985) Die Pflanzenreste der neolithischen Ufersiedlung von HornstaadHörnle I am westlichen Bodensee, 1.Bericht. Berichte zu Ufer- und Moorsiedlungen Südwestdeutschlands 2. Materialefte zur Vor- u. Frühgeschichte in Baden-Württemberg 7: 164-199.

Rösch M. (1987) Zur Umwelt und Wirtschaft des Jungneolithikums am Bodensee Botanische Untersuchungen in Bodman-Blissenhalde. Archäologische Nachrichten aus Baden 38/39: 42-53.

Rösch M. (1990a) Botanische Untersuchungen an Pfahlverzügen der endneolithischen Ufersiedlung Hornstaad-Hörnle V am Bodensee. In: Siedlungsarchäologie im Alpenvorland II. Stuttgart: Konrad Theiss Verlag, 325-351.

Rösch M. (1990b) Botanische Untersuchungen in spätneolithischen Ufersiedlungen von Wallhausen und Dingelsdorf am Überlinger See (Kr. Konstanz). In: Siedlungsarchäologie im Alpenvorland II. Stuttgart: Kontrad Theiss Verlag, 227266.

Rösch M. (1990c) Hegne-Galgenacker am Gnadensee. Erste botanische Daten zur Schnurkeramik am Bodensee. In: Siedlungsarchäologie im Alpenvorland II. Stuttgart: Konrad Theiss Verlag, 199-225.

Schaal C. (2000) Etude carpologique d'un village néolithique: la station 19 de Chalain (Jura) au 30ème siècle av. J.-C. Master Thesis, Besançon: Université de Franche Comté.

Schlichtherle H. (1985) Samen und Früchte: Konzentrationsdiagramme pflanzlicher Grossreste aus einer neolithischen Seeuferstratigraphie, Freiburg i. Br.

van Zeist WA and Boekschoten-van Helsdingen AM. (1991) Samen und Früchte aus Niederwil. In: Waterbolk HT and van Zeist WA (eds) Niederwil. Eine Siedlung der Pfyner Kultur. Band III: Naturwissenschaftliche Untersuchungen. Bern / Stuttgart: Verlag Paul Haupt, 49-113.

Villaret - von Rochow M. (1967) Frucht- und Samenreste aus der neolithischen Station Seeberg, Burgäschisee-Süd. Seeberg Burgäschisee Süd, Teil 4: Chronologie und Umwelt. Bern: Verlag Stämpfli \& Cie, 21-63. 
Wolf C. (1993) Die Seeufersiedlung Yverdon, Avenue des Sports (Kanton Waadt). Cahiers d'Archéologie Romande (CAR) 59.

Zibulski P. (2010) Botanik. In: Eberli U (ed) Die horgenzeitliche Siedlung Pfäffikon-Burg. Zürich und Elgg: Baudirektion des Kantons Zürich, 236-255. 


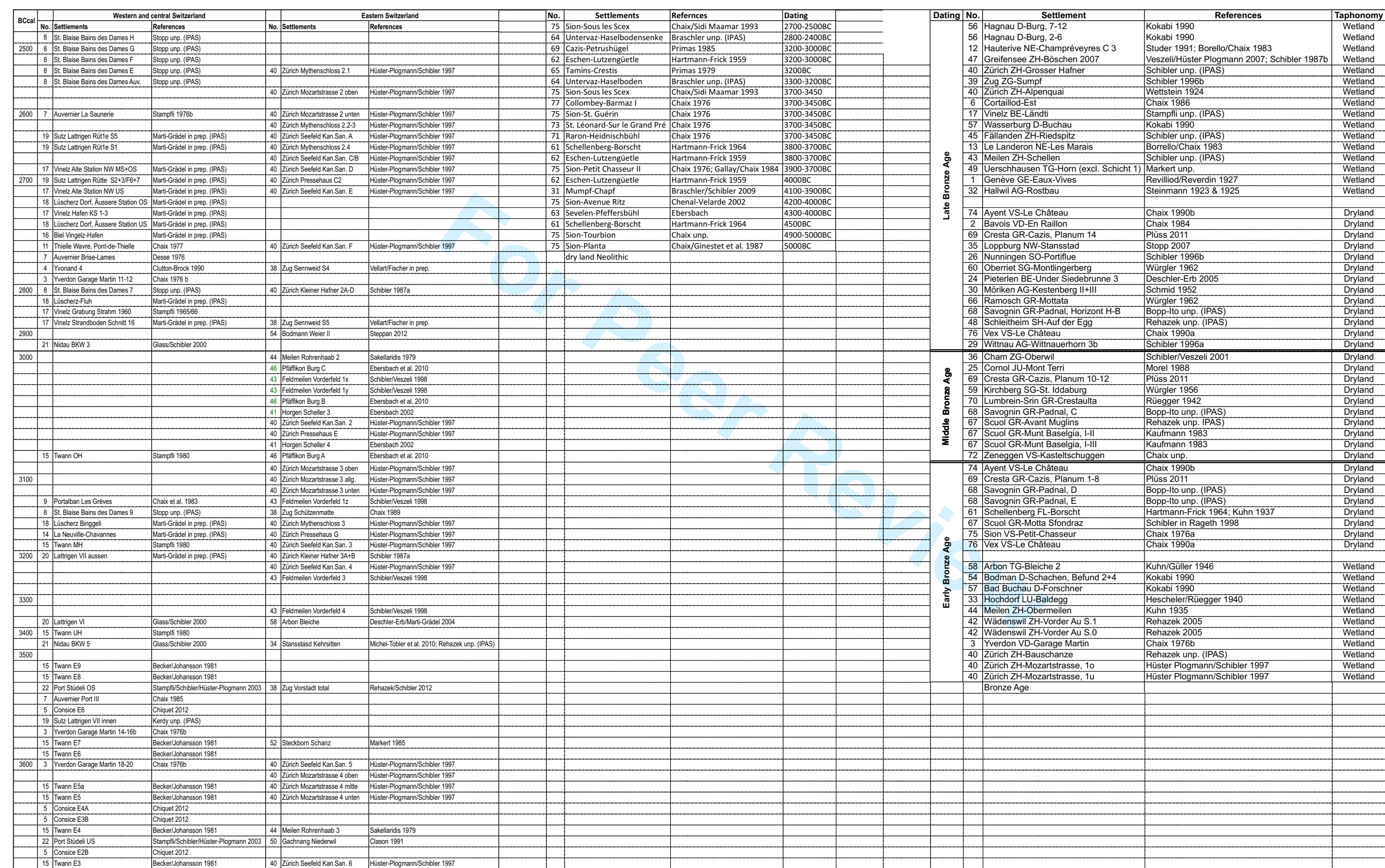




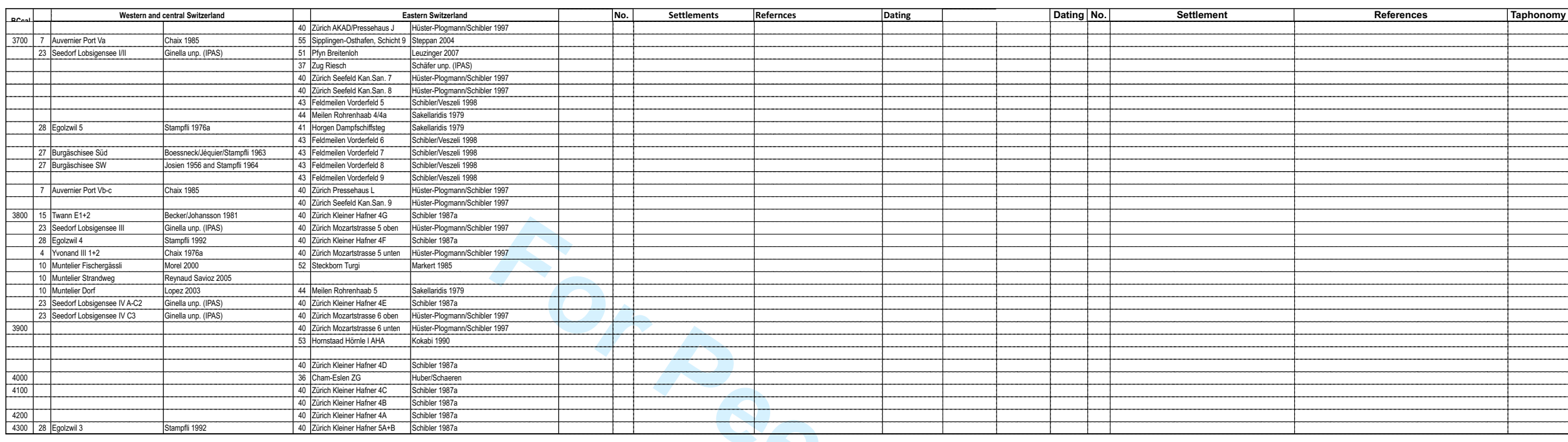




\section{References to OSM Table 3 (and Figure 4)}

Becker, C. and Johansson, F. (1981) Die Tierknochenfunde. Zweiter Bericht. Die neolithischen Ufersiedlungen von Twann. Vol. 11 Bern. Haupt Verlag.

Boessneck, J., Jéquier, J.-P. and Stampfli, H.R. (1963) Seeberg Burgäschisee-Süd, Teil 3: Die Tierreste. Acta Bernensia II. Bern: Stämpfli Verlag.

Bopp-Ito, M. (2010) Animal husbandry in the Bronze Age alpine settlement "Padnal", Switzerland. BoneCommons, Item \# 988 (accessed October 11, 2010)

Borello, M. A. and Chaix, L. (1983) Étude de la faune de Hauterive-Champréveyres (Neuchâtel): Bronze final (1979-1980). Extrait du Bulletin de la société neuchâteloise des sciences naturelles, 106, 159-169.

Braschler, S. (unpubl.) Forschungen zur Wirtschaftsgeschichte neolithischer Trockenbodensiedlungen der Schweiz. Unpubl. Master thesis, Universität Basel (IPNA).

Braschler, S. and Schibler, J. (2009) Archäozoologische Auswertung der neolithischen Tierknochen aus der Fundstelle Mumpf AG-Kapf. Jahrbuch Archäologie Schweiz 92, 3842.

Chaix, L. (1976a) La faune de la station d'Yvonand III. Jahrbuch Schweizerische Gesellschaft für Ur- und Frühgeschichte, 59, 61-65.

Chaix, L. (1976b) „La faune de la fouille Yverdon-Garage Martin“, in Kaenel, G. (ed.) La fouille du "Garage Martin-1973". Cahiers d'Archéologie Romande, vol. 6, pp. 181-228. Lausanne: Musée d'archéologie et d'histoire.

Chaix, L. (1976c) La faune néolithique du Valais (Suisse). Ses caractères et ses relations avec les faunes néolithiques des régions proches. Unpubl. PhD Thesis, University of Geneva. Genève.

Chaix, L. (1976d) La faune du dolmen MXI à Sion (Valais, Suisse). Problèmes d'interprétation, in J. P. Millotte, J.P., Thévenin, A. and Chertier, B. (eds.) Actes $d u 9 e$ congress de l'Union international des Sciences préhistoriques et protohistoriques, themes specialises, pp. 56-74. Nice: CNRS.

Chaix, L. (1977) La faune de la station de Pont-de-Thielle (néolithique récent). Archives scientifiques, 30(3), 433-464.

Chaix, L. (1986) « La faune », in Borello, M.A., Brochier, J-L., Chaix, L. and Hadorn, Ph. (eds.) Nature et environnement. Cortaillod-Est, un village du Bronze final 4. Archéologie neuchâteloise vol. 4, pp. 47-73. Neuchâtel: Office et musée cantonal d'archéologie.

Chaix, L. (1989) La faune du site de Schützenmatt. Jahrbuch Schweizerische Gesellschaft für Ur- und Frühgeschichte, 72, 43-48. 
Chaix, L. (1990a) La faune de Vex-le-Château (Valais, Suisse; du Néolithique moyen au Bronze final). Jahrbuch Schweizerische Gesellschaft für Ur- und Frühgeschichte, 73, 47 50 .

Chaix, L. (1990b) La faune d'Ayent-le-Château (Valais, Suisse; Bronze ancien et Bronze final). Jahrbuch Schweizerische Gesellschaft für Ur- und Frühgeschichte, 73, 44-46.

Chaix, L., Olive, C., Ramseyer, D. and Studer, J. (1983) La faune des secteurs 33 et 38 de la station néolithique Portalban/Les Grèves (civilisation de Horgen). Bulletin Société Fribourgoise Sciences Naturelles, 72 (1/2), 44-55.

Chaix, L. (1984) Les restes de vertébrés du site de Bavois-en-Raillon (Vaud, Suisse) (Bronze final) in: Vital, J. and Voruz, J. - L. (eds.) L'habitat protohistorique de Bavois-enRaillon (Vaud). Cahiers d'Archéologie Romande vol. 28, pp. 67-80. Lausanne: Musée d'archéologie et d'histoire.

Chaix, L. (1988) Les grands traits de l'évolution des faunes de mammifères (domestiques et sauvages) du Néolithique moyen II au final au Nord-Ouest des Alpes, in Pétrequion, P. (ed.) Du Néolithique moyen II au Néolithique final au Nord-Ouest des Alpes. Actes du 12e Colloque interrégional sur le Néolithique de l'Est de la France, Lons-leSaunier, 11-13 octobre 1985, pp. 205-215. Lons-le-Saunier : Musée d'archéologie.

Chaix, L., Ginestet, J.-P. and Olive, C. (1987) « Nouvelles données sur l'élevage au Néolithique ancien dans les Alpes du Nord » in Guilaine, J. (ed.) Premier Communautés Paysannes en Méditerranée occidentale. Colloque International du CNRS, Montpellier 2629 Avril 1983, pp. 189 - 192. Paris : CNRS.

Chaix, L. and Sidi Maamar, H. (1993) La chasse au Néolithique dans les Alpes du Nord (Valais, Italie du Nord, Haute-Savoie et Dauphiné): des données archéozoologiques aux modélisations archéologiques, in Exploitation des Animaux sauvage à travers le temps. XIIIe Recontres Internationales d'Archéologie et d'Histoire d'Antibes. Ive Colloque international de l'Homme et l'Animal, Société de Recherche Interdisciplinaire pp. 161181. Juan-les-Pins : APDCA

Chenal-Velarde, I. (2002) La faune du site néolithique de Sion-Avenue Ritz (Valais, Suisse). Historie d'un élevage villageois il y a 5000 ans. British archeological report, International Series 1081. Oxford: Archaeopress.

Chiquet, P. (2012) „La faune du Néolithique moyen: analyse des modes d'exploitation des ressources animales et contribution à l'interprétation de l'espace villageois“, in La station lacustre de Concise 4. Cahiers d'Archéologie Romande vol. 131. Lausanne: Musée d'archéologie et d'histoire.

Clason, A.T., (1991) Viehzucht, Jagd und Knochenindustrie der Pfyner Kultur. In: H.T. Waterbolk and W. van Zeist ed., Niederwil. Eine Siedlung der Pfyner Kultur. Bd. III: Naturwissenschaftliche Untersuchungen. Academia Helvetica 1 III, pp. 115-220. Bern and Suttgart: Verlag Paul Haupt. 
Clutton-Brock, J. (1990) Animal remains from the Neolithic Lake Village Site of Yvonand IV, Canton de Vaud, Switzerland. Archives Scientifiques 43(1), 1-97.

Desse, J. (1976) La faune du site archéologique Auvernier-Brise Lames, canton de Neuchâtel (Suisse). Thèse Poitiers 1976.

Deschler-Erb, Sabine und Marti-Grädel, Elisabeth (2004). „Viehhaltung und Jagd. Ergebnisse der Untersuchung der handaufgelesenen Tierknochen“, in: Jacomet, S., Leuzinger, U. and Schibler, J. (eds.) Die jungsteinzeitliche Seeufersiedlung Arbon / Bleiche 3: Umwelt und Wirtschaft. Archäologie im Thurgau vol. 12, pp. 158-252. Frauenfeld: Huber \& Co AG.

Deschler-Erb, S. (2005) “Archäozoologie” in Suter P.J. and Ramstein, M. (eds.), Fundberichte und Aufsätze / Chronique archéologique et textes. Archäologie im Kanton Bern vol 6, 108-109.

Ebersbach, R. (2002) „Archäozoologie“, in Achour-Uster, C., Eberli, U., Ebersbach, R. and Favre, P. (eds.), Die Seeufersiedlungen in Horgen. Die neolithischen und bronzezeitlichen Fundstellen Dampfschiffsteg und Scheller. Monografien der Kantonsarchäologie Zürich vol. 36, pp. 181-203. Zürich: Fotorotar.

Ebersbach, R. (2005) „Die Tierknochen aus den Epi-Rössener Schichten“, in Rigert, E., Ebneter, I., Ebersbach, R., Akeret, Ö. and Leuzinger, U. (eds.) Die Epi-Rössener Siedlung von Sevelen SG-Pfäfersbüel. Jahrbuch der Schweizerischen Gesellschaft für Ur- und Frühgeschichte vol. 88, $41-86$.

Ebersbach, R., Hüster-Plogmann, H., Stopp, B. and Schibler, J. (unter Mitarbeit von K. H. Steppan) „Archäozoologie“ in Eberli, U. (ed.) Die horgenzeitliche Siedlung Pfäffikon-Burg. Monographien der Kantonsarchäologie Zürich vol. 40, pp. 262-299. Zürich: Fotorotar.

Gallay, A. and Chaix, L. (1984) Le site préhistorique du Petit Chasseur (Sion, Valais). Le Dolmen M XI. Cahiers d'Archéologie Romande vol. 31. Lausanne: Musée d'archéologie et d'histoire.

Ginella, F. and Schibler, J. (in prep.) Die Grosstierknochen aus den neolithischen Schichten von Lobsigensee. Unpubl. Data IPAS.

Glass, M. and Schibler, J. (2000) „Archäozoologsiche Auswertung der Tierknochen“, Hafner, A. and Suter, P.J. (eds.) 3400 v.Chr. - Die Entwicklung der Bauerngesellschaften im 4. Jahrtausend v.Chr. am Bielersee aufgrund der Rettungsgrabungen von Nidau und SutzLattrigen. Ufersiedlungen am Bielersee - Band vol.6, pp. 139-154. Bern: Berner Lehrmittel- und Medienverlag.

Gutzwiller, P., Marti, R., Schibler, J. Sedlmeier, J. and Veszeli, M. (1996) Zufluchtsort in unsicherer Zeit. Die Portifluh als markanter Zeuge früher Besiedlung. Heimatbuch „Nunningen“, pp. 75-84. Breitenbach: Verlag Jeger-Moll.

Hartmann-Frick, H. (1959) Die Tierwelt des prähistorischen Siedlungsplatzes auf dem Eschner Lutzengüetle Fürstentum Liechtenstein (Neolithikum bis La Tène). Jahrbuch des Historischen Vereins für das Fürstentum Liechtenstein 59, 5 - 224. 
Hartmann-Frick, H. (1965) Die Fauna der befestigten Höhensiedlung auf dem Borscht Fürstentum Liechtenstein (Neolithikum bis La Tène). Jahrbuch des Historischen Vereins für das Fürstentum Liechtenstein 64, 189 - 253.

Hescheler, K. and Rüegger, J. (1940) Die Wirbeltierreste aus den Pfahlbauten des Baldeggersees nach den Grabungen von 1938 und 1939. Vierteljahrsschrift der Naturforschenden Gesellschaft in Zürich 85. 59-70.

Hüster-Plogmann, H., Schibler, J. (1997) “Archäozoologie”, in Schibler, J., Hüster Plogmann, H., Jacomet, S., Brombacher, C., Gross-Klee, E. and Rast-Eicher, A., Ökonomie und Ökologie neolithischer und bronzezeitlicher Ufersiedlungen am Zürichsee. Monographien der Kantonsarchäologie Zürich vol. 20. pp. 40-121. Zürich: Fotorotar.

Josien, Th. (1956) Étude de la faune des gisements néolithiques (niveau Cortaillod) du canton Berne (Suisse). Archives Suisses d'Anthropologie générale 21(1), 28-62.

Kaufmann, B. (1983) „Die Skelettreste von Scuol-Munt, Baselgia“, in Stauffer-Isenring, L. (ed.) Die Siedlungsreste von Scuol-Munt, Baselgia (Unterengadin, GR). Antiqua vol. 9, pp. 164-179. Basel: Schweizerische Gesellschaft für Ur- und Frühgeschichte.

Kerdy, M. (unpubl.) An archaeozoological and taphonomical analysis oft the animal bones accumulations of the Neolithic lake shore site "Sutz-Lattrigen VII Hauptstation innen, lake Bienne, Switzerland". Unpublished Master Thesis, University of Basel (IPAS)

Kokabi, M. (1990) Ergebnisse der osteologischen Untersuchungen an den Knochenfunden von Hornstaad im Vergleich zu anderen Feuchtbodenfundkomplexen Südwestdeutschlands. In: Siedlungsarchäologische Untersuchungen im Alpenvorland. 5. Kolloquium der Deutschen Forschungsgemeinschaft vom 29.-30. März 1990 in Gaienhofen Hemmenhofen. Bericht der Römisch-Germanischen Kommission, 71, 145-160.

Kuhn, E. (1935) Die Fauna des Pfahlbaues Obermeilen am Zürichsee. Vierteljahrsschrift der Naturforschenden Gesellschaft in Zürich, 80, 65-154.

Kuhn, E. (1937) Die Fauna der Wallsiedlung im Borscht (Endneolithikum-La Tène). Jahrbuch des Historischen Vereins für das Fürstentum Liechtenstein, 37, 4-42.

Kuhn, E. and Güller, A. (1946) Die Tierreste des bronzezeitlichen Pfahlbaues in der Bleiche von Arbon (Kt. Thurgau). Eclogae Geologicae Helvetiae, 39, Basel, 364-366, 946.

Leuzinger, U. (2007). Pfyn Breitenloo - die jungsteinzeitliche Pfahlbausiedlung. Archäologie im Thurgau, vol. 14. Frauenfeld: Amt für Archäologie Thurgau

Lopez, C. (2003). Archéozoologie de la station néolithique de Muntelier-Dorf (canton de Fribourg). Mémoire de licence, université Neuchâtel.

Markert, D. (1985a) Die Fauna der Grabung Steckborn-Schanz, in Winiger, J. and Hasenfratz, A. (eds.) Ufersiedlungen am Bodensee. Archäologische Untersuchungen im Kanton Thurgau 1981-1983. Antiqua vol. 10, Basel: Schweizerische Gesellschaft für Urund Frühgeschichte, pp. 150-153. 
Markert, D. (1985b) Die Fauna der Grabung Steckborn-Turgi, in Winiger, J. and Hasenfratz, A. (eds.) Ufersiedlungen am Bodensee. Archäologische Untersuchungen im Kanton Thurgau 1981-1983. Antiqua vol. 10, Basel: Schweizerische Gesellschaft für Urund Frühgeschichte, pp. 58 and 70

Michel-Tobler, Ch., Brombacher, Ch. and Rehazek, A. (2010). Stansstad-Kehrsiten Neolithische Seeufersiedlungen hart am Alpenrand, in Matuschik and Strahm, Ch. (eds.) Vernetzungen. Aspekte siedlungsarchäologischer Forschung. Festschrift für Helmut Schlichtherle zum 60. Geburtstag, pp. 287-296. Freiburg/Br.: Lavori Verlag

Morel, Ph. (1988) Kommentar zu den Tierknochen aus Schnitt 6 <Schichtpaket>. In: Müller, F. (ed.) Mont Terri 1984 und 1985 - Ein Grabungsbericht. Jahrbuch der Schweizerischen Gesellschaft für Ur- und Frühgeschichte Band 71, 28.

Morel, Ph. (2000) La faune: détermination ostéologique, in Ramseyer, D. (ed.) Munterlier / Fischergässli. Un habitat néolithique au bord du lac de Morat (3895 à 3820 avant J.-C.). Archéologie fribourgeoise, vol. 15. Fribourg: Sérvice archéologique cantonal.

Plüss, P. (2011) Die bronzezeitliche Siedlung Cresta bei Cazis (GR): Die Tierknochen. Collectio archæologica vol. 9, Zürich: Chronos Verlag.

Primas, M. (1979) Archäologische Untersuchungen in Tamins GR: Die spätneolithische Station „Crestis“. Jahrbuch der Schweizerischen Gesellschaft für Ur- und Frühgeschichte, $62,13-27$.

Primas, M. (1985) Cazis-Petrushügel in Graubünden. Neolithikum, Bronzezeit, Spätmittelalter. Zürcher Studien zur Archäologie 4, Zürich: Juris.

Rehazek, A. (2005) Archäozoologie (Frühe Bronzezeit und Schnurkeramik), in Conscience, A.- C. (ed.) Wädenswil-Vorder AU. Eine Seeufersiedlung am Übergang vom 17. zum 16. Jh. v. Chr. Im Rahmen der Frühbronzezeit am Zürichsee. Unter besondere Berücksichtigung der frühbronzezeitlichen Funde und Befunde von Meilen-Schellen. Zürcher Archäologie, Seeufersiedlungen, Heft 19, pp. 32-37. Zürich : Hochbauamt Kantonsarchäologie.

Rehazek, A. (unpubl.) Archaeozoological data of the Neolithic site of Cham-Eslen (canton Zoug). Unpublished manuscript IPAS, University of Basel.

Rehazek, A. and Schibler, J. (2012) Archäozoologische Untersuchung der Tierknochen aus der Siedlung des jüngeren Neolithikums von Zug-Vorstadt, Rettungsgrabung 1991, in Widmer, A. B. Die Siedlungsreste aus dem jüngeren Neolithikum von Zug-Vorstadt, Rettungsgrabung 1991. Jahrbuch Archäologie Schweiz 95, 62-67.

Reveillod, P. and Reverdin, L. (1927) Les ossementa d'animaux de la station lacustre des Eaux-Vives (Genève). Verhandlungen der Schweizerischen Naturforschenden Gesellschaft $108,240$. 
Reynaud Savioz, N. (2005). La faune. In: Mauvilly, M. and Boisaubert, J.-L. (eds.) Montilier/Dorf, fouilles Strandweg 1992/1993, nouvelles données sur la Culture Cortaillod au bord du lac de Morat, Cahiers d'Archéologie Fribourgeoise vol. 7, pp. 29-37. Fribourg: Service archéologique de l'Etat.

Rüeger, J. (1942) Die Tierreste aus der spätbronzezeitlichen Siedlung Crestaulta (Kanton Graubünden) nach den Graubunden 1935-1938. Revue Suisse de Zoologie, 49, 251-267.

Sakellaridis, M.E. (1979) The Economic Exploitation of the Swiss Area in the Mesolithic and Neolithic Periods. BAR International Series 67, Oxford: Archaeopress.

Schibler, J. (1987a) Osteoarchäologische Untersuchungen der neolithischen Knochenkomplexe, in Suter, P.J. Zürich "Kleiner Hafner". Tauchgrabungen 1981-1984. Berichte der Zürcher Denkmalpflege, Monographien vol. 3, pp. 167-179. Zürich: Orell Füssli.

Schibler, J. (1987b) Die Tierknochen aus der spätbronzezeitlichen Siedlung GreifenseeBöschen, Kt. Zürich, in: Eberschweiler, B., Riethmann, P. and Ruoff, U. (eds.) GreifenseeBöschen ZH: Ein spätbronzezeitliches Dorf. Ein Vorbericht. Jahrbuch der Schweizerischen Gesellschaft für Ur- und Frühgeschichte, vol. 70, p. 80. Frauenfeld: Huber \& Co.

Schibler, J. (1996a) Archäozoologische Auswertung der Tierknochen, in Berger, L., Brianza, M., Gutzwiller, P., Joos, M. and Rentzel, Ph. (eds.) Sondierungen auf dem Wittnauer Horn 1980-1982. Basler Beiträge zur Ur- und Frühgeschichte vol. 14, pp. 7173. Basel: Schwabe Verlag.

Schibler, J. (1996b) Die Tierknochen der Seeufersiedlungen von Zug-Sumpf und ihre Bedeutung im Rahmen der bronzezeitlichen Wirtschaft im nördlichen Alpenvorland, in Seifert, M., Jacomet, S., Schibler, J. (eds.) Die spätbronzezeitlichen Ufersiedlungen von ZugSumpf. 1, Die Dorfgeschichte, pp. 305-348. Zug: Kantonales Museum für Urgeschichte.

Rageth, J. (1998) Ein prähistorischer Kultplatz auf Scuol-Motta Sfondraz. Archäologischer Dienst Graubünden Denkmalpflege Graubünden. Jahresberichte 1998, 3446.

Schibler, J, and Veszeli, M. (1998) Neue, stratifizierte Ergebnisse aus neolithischen Seeufersiedlungen von Feldmeilen-Vorderfeld ZH und ihre Bedeutung für die Wirtschaftsarchäologie, in Römerstadt Augusta Raurica (ed.) Mille Fiori: Festschrift für Ludwig Berger, Forschungen in Augst vol. 25, pp. 313-322. Augst: Römermuseum Augst.

Schmid, E. (1952) Die Tierknochen vom Kestenberg, Grabung 1951. Ur-Schweiz 16, 4. 96.

Stampfli, H.R. (1964) Vergleichende Betrachtungen an Tierresten aus zwei neolithischen Ufersiedlungen am Burgäschisee. Mitteilungen der Naturforschenden Gesellschaft Bern, 21, 113-136.

Stampfli, H.R. (1966) Die Knochenfunde der Grabung Vinelz 1960. Jahrbuch des Bernisch Historischen Museums, 45/46, 319-320. 
Stampfli, H.R. (1976a) Die Tierknochen von Egolzwil 5, Osteo-archäologische Untersuchungen, in Wyss, R. (ed.) Das jungsteinzeitliche Jäger-Bauerndorf von Egolzwil5 im Wauwilermoos, pp. 125-140. Zürich: Schweizerisches Landesmuseum Zürich.

Stampfli, H.R. (1976b) Osteo-Archäologische Untersuchung des Tierknochenmaterials der spätneolithischen Ufersiedlung Auvernier-La Saunerie nach den Grabungen 1964 und 1965. Solothurn: Eigenverlag.

Stampfli, H.R. (1980) Tierknochenfunde. Dokumentation, in Furger, A.R. Die Siedlungsreste der Horgener Kultur. Die neolithischen Ufersiedlungen von Twann, vol. 7, pp. 141-160. Bern: Paul Haupt Verlag.

Stampfli, H.R. (1992) Die Tierknochen aus den jungsteinzeitlichen Siedlungen Egolzwil 3 und 4. Archäologische Schriften Luzern, vol. 1. Luzern: Kantonsarchäologie.

Stampfli, H.R., Hüster Plogmann, H., Schibler, J. (2003) Viehhaltung und Jagd, in H. Zwahlen, H. (ed.) Die jungneolithische Siedlung Port-Stüdeli. Ufersiedlungen am Bielersee, vol. 7, pp. 61-65. Bern: Staatlicher Lehrmittelverlag.

Steinmann, P. (1923) Über die Fauna der Pfahlbauten im Hallwilersee. Mitteilungen der Aargauischen Naturforschenden Gesellschaft, 16, 59-63.

Steinmann, P. (1925) Weitere Knochenreste vom bronzezeitlichen Rostbau bei Hallwil. Mitteilungen der aargauischen naturforschenden Gesellschaft, vol. 17, 184-186.

Steppan Karlkeinz (2004) Die Tierknochenfunde aus der Schicht 9 von SipplingenOsthafen, in Billamboz, A., Riehl, S., Schmidt, E. and Steppan, K. (eds.) Siedlungen der Pfyner Kultur im Osten der Pfahlbaubucht von Sipplingen, Bodenseekreis, vol. 2: Naturwissenschaftliche Untersuchungen. Hemmenhofener Skripte vol. 4., pp. 87-96. Gaienhofen-Hemmenhofen: Janus Verlag.

Steppan, K. (2012) Die Tierknochenfunde aus der Seeufersiedlung Bodmann-Weiler II, Kr. Konstanz. Ein Beitrag zu Viehwirtschaft und Jagd der Horgener Kultur am Überlinger See. Hemmenhofener Skripte, 7, 55-66.

Stopp, B. (2007) Tierknochen, Zahn- und Geweihfragmente, in Obrecht, J. and Gutzwiller, P. (eds.) Die Loppburg- eine befestige Höhensiedlung, Resultate der Ausgrabungen von 2001 in einer vermeintlich mittelalterlichen Burg, Antiqua, vol 42, pp. 119-122. Basel: Archäologie Schweiz.

Stopp, B. (unpubl.) Archaeozoological data from St. Blaise Bains des Dames. Unpublished Master Thesis, IPAS University of Basel 1989.

Studer, J. (1991) La faune de l'âge de bronze final du site d'Hauterive-Champréveyres (Neuchâtel, Suisse). Thèse de l'Université de Genève, Genève.

Vellart, I. and Fischer, M. (2006) Die Tierknochen der Rettungsgrabungen 1988 - 91, in Röder, B. and Huber, R. (eds.) Archäologie in Steinhausen „Sennweid“ (Kanton Zug). Ergebnisse der Untersuchungen von 1942 - 2000, Antiqua, vol. 41, pp. 292-203. Basel: Archäologie Schweiz. 
Veszeli, M. (2001) Restliche Tierknochen aus der Siedlung, in: Gnepf Horisberger, U. and Hämmerle, S. (eds.) Cham-Oberwil, Hof (Kanton Zug). Befunde und Funde aus der Glockenbecherkultur und der Bronzezeit, Antiqua, vol. 33, pp. 146-149. Basel:

Archäologie Schweiz.

Veszeli, M. and Hüster Plogmann, H. (2007) Die Tierknochen, in Eberschweiler, B., Riethmann, P. and Ruoff, U. (eds.) Das spätbronzezeitliche Dorf von Greifensee-Böschen, Dorfgeschichte, Hausstrukturen und Fundmaterial. Monographien der Kantonsarchäologie, vol. 38, pp. 232-234. Zürich und Egg: Fotorotar.

Wettstein, E. (1924) Die Tierreste aus dem Pfahlbau am Alpenquai in Zürich. Vierteljahrsschrift der Naturforschenden Gesellschaft Zürich, 69. 78-127.

Würgler, F. (1956) Beitrag zur Kenntnis der mittelalterlichen Fauna der Schweiz. Burgstellen: Iddaburg, Clanx, Hohensax, Starkenstein. Jahrbuch der St. Gallischen Naturwissenschaftlichen Gesellschaft, 75, 1-90.

Würgler, F. (1962) Veränderungen des Haustierbestandes während der Bronze- und Eisenzeit in den zwei schweizerischen „Melauner"-Stationen, Montlingerberg und Mottata Ramosch. Zeitschrift für Tierzüchtung und Züchtungsbiologie, 77, 1, 35-46. 


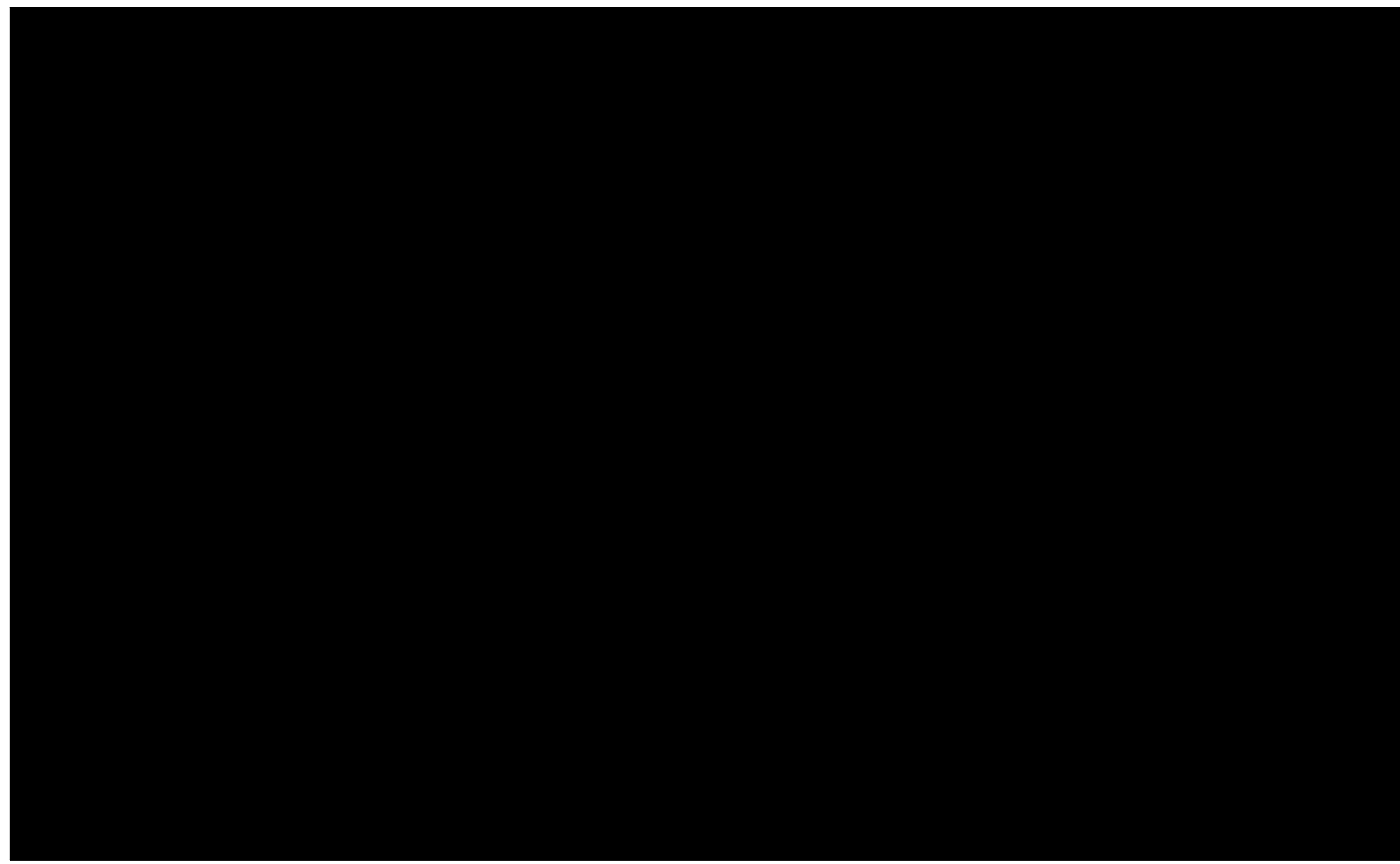




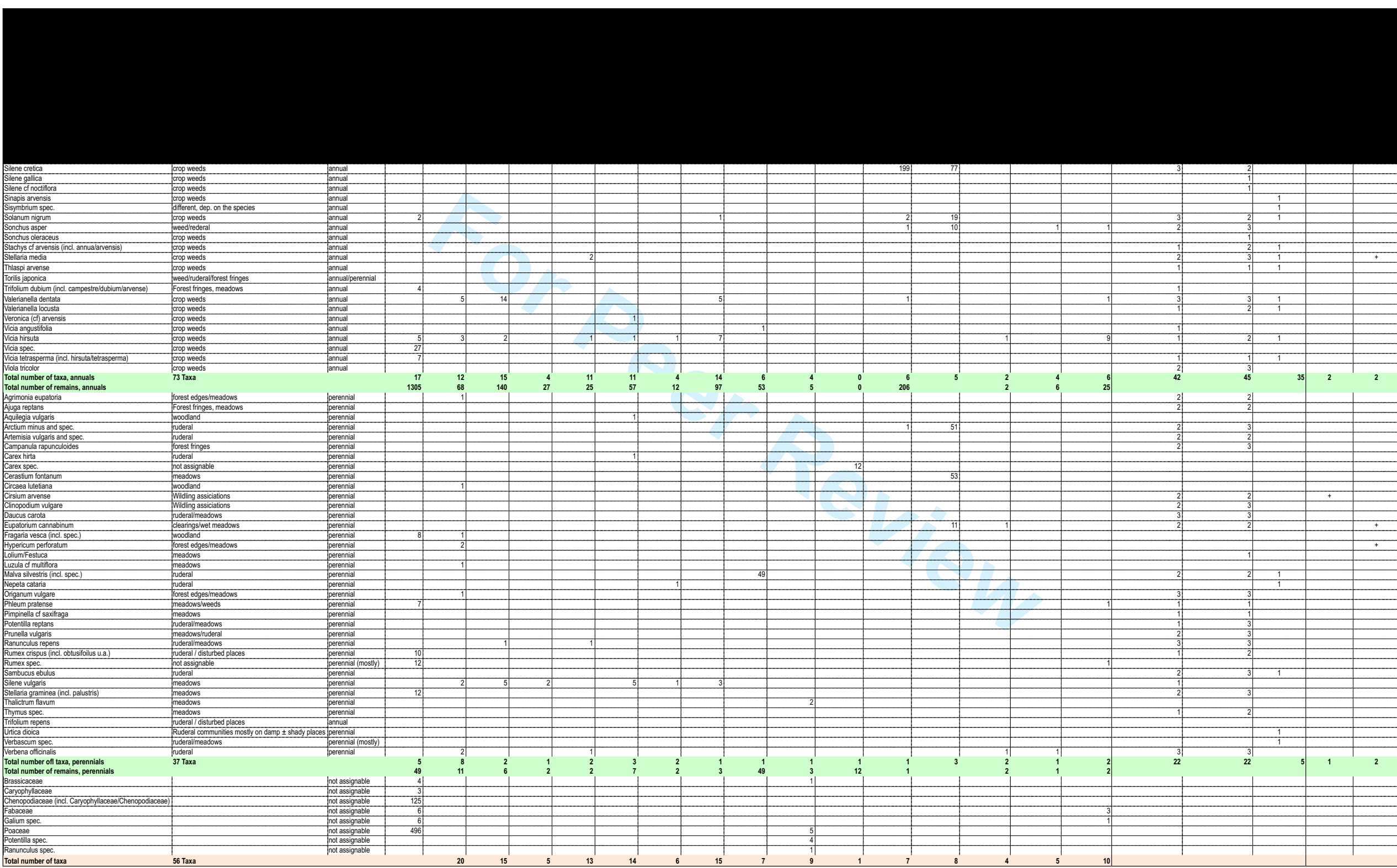




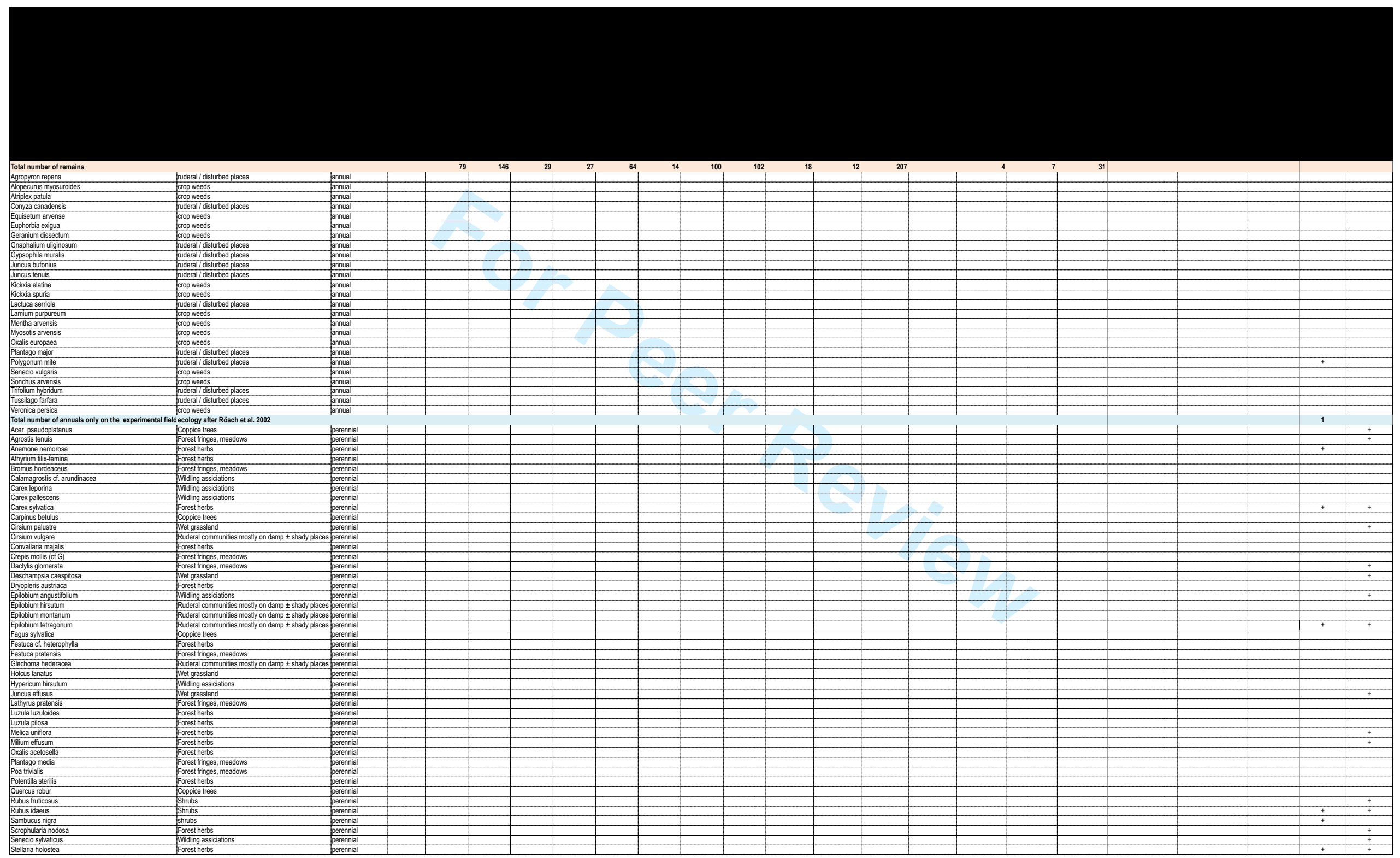




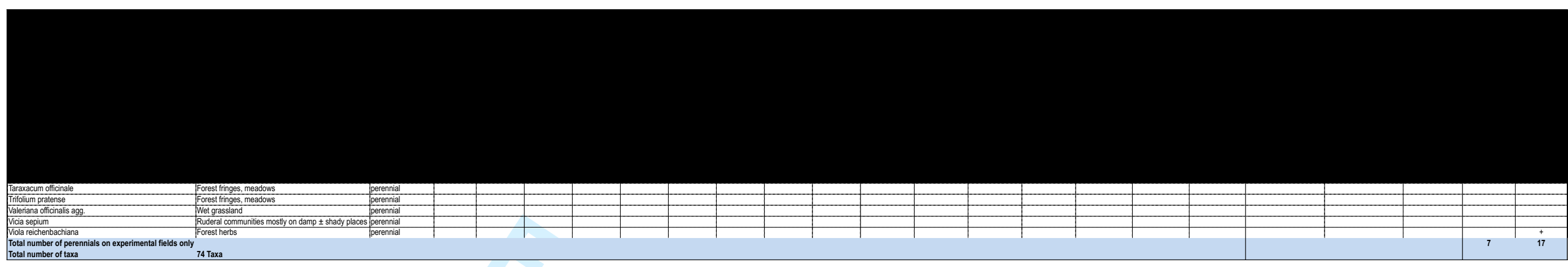




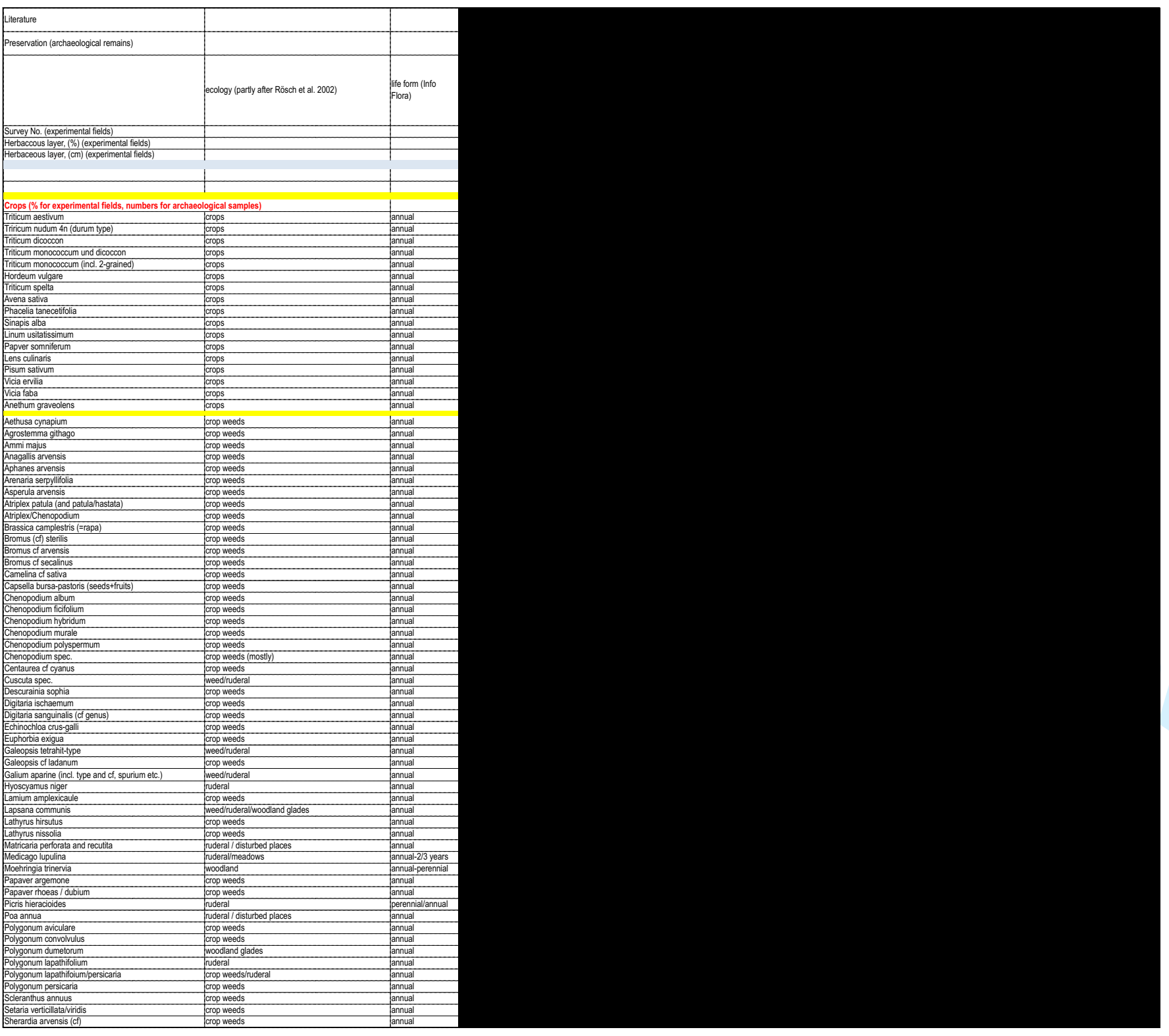




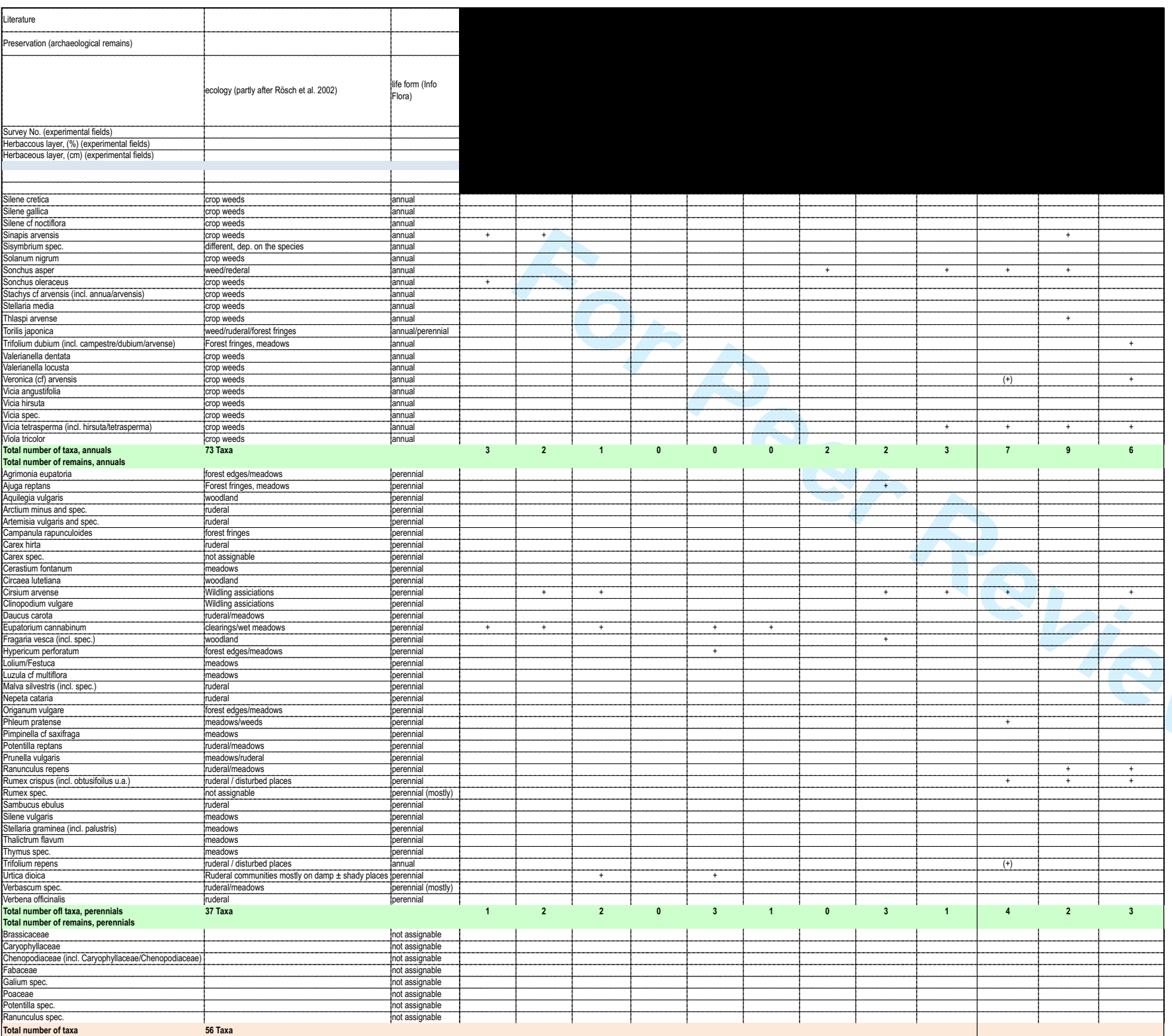




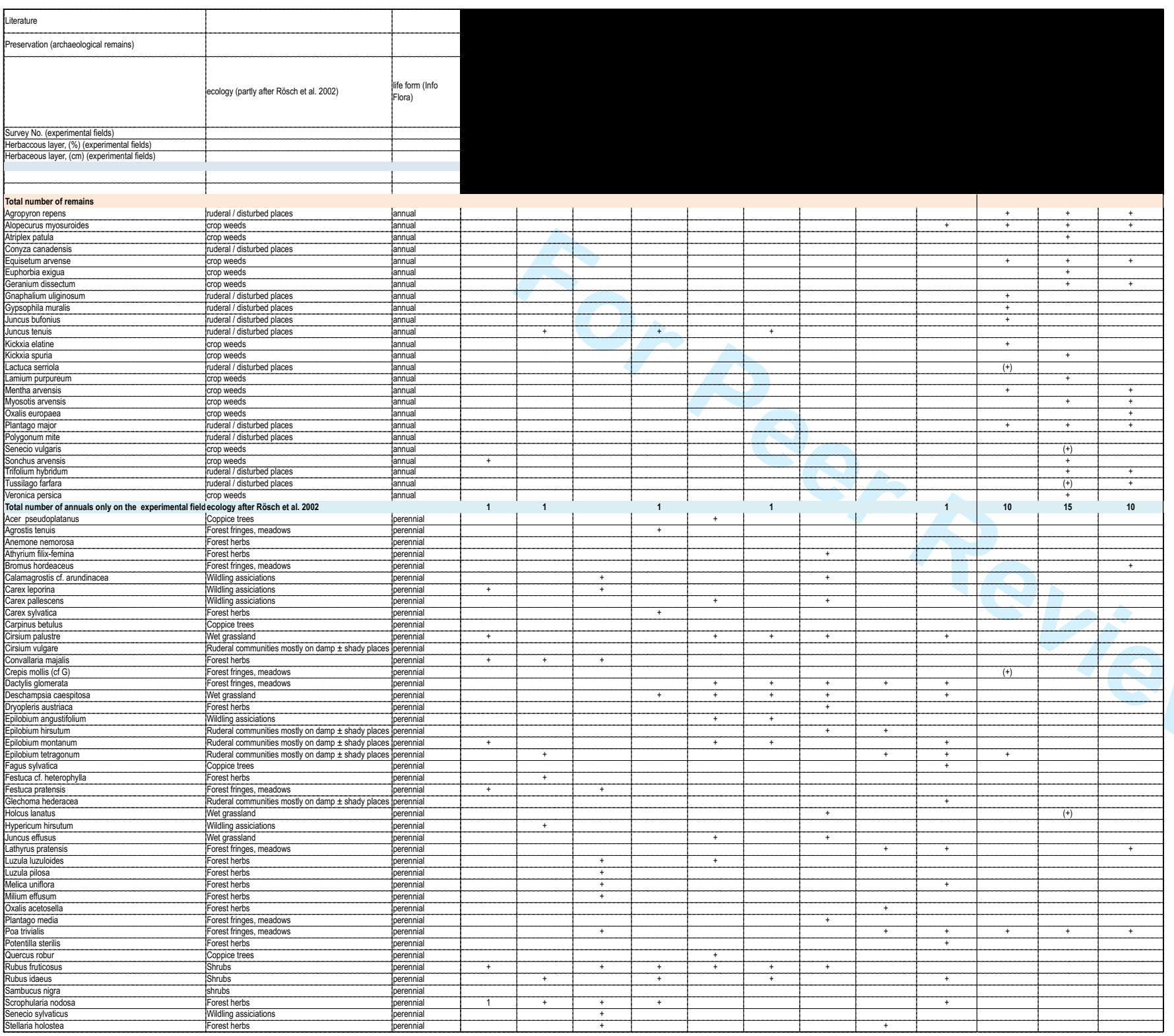




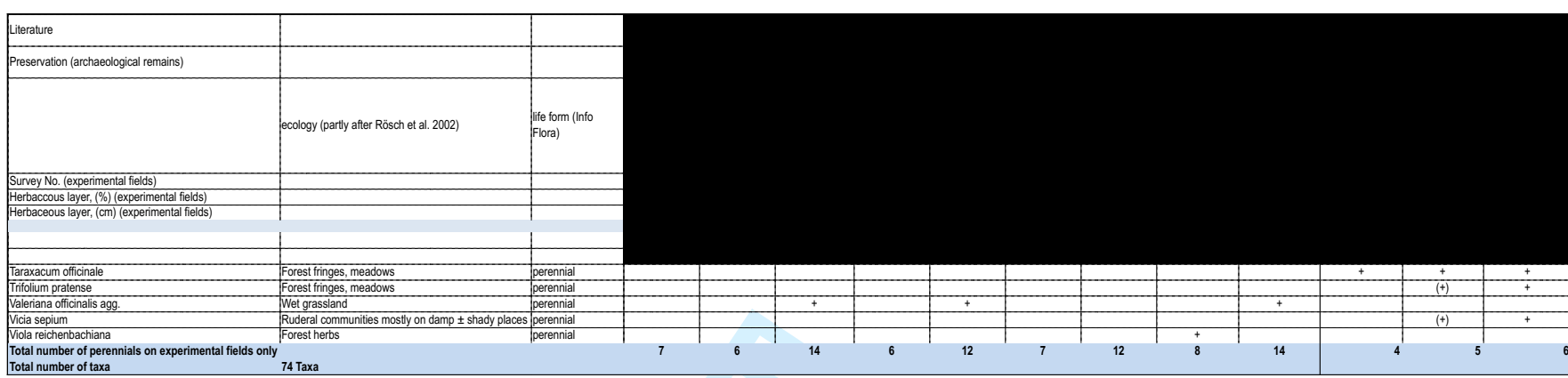

3

15

16

17

18

19

20

21

22

23

24

25

26

27

29

33

37 